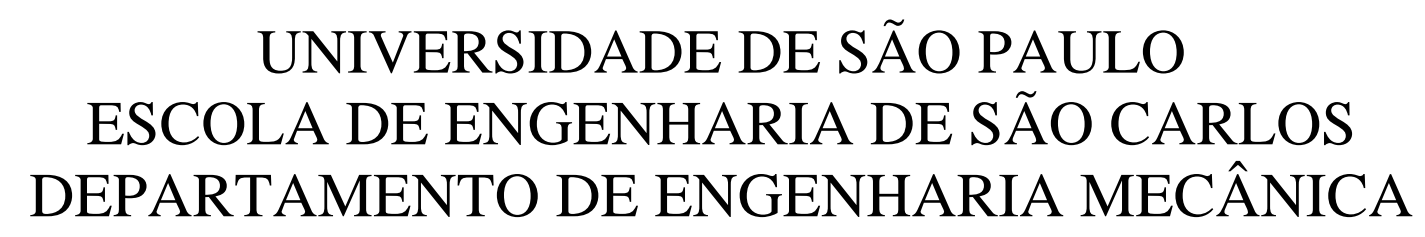

BRENO ORTEGA FERNANDEZ

\title{
PROPOSTA DE UM SISTEMA ELETRÔNICO EMBARCADO PARA FISCALIZAÇÃO AUTOMÁTICA DE VEÍCULOS RODOVIÁRIOS DE CARGA
}

São Carlos

2010 



\section{Breno Ortega Fernandez}

Mestre em Engenharia Mecânica

\section{PROPOSTA DE UM SISTEMA ELETRÔNICO EMBARCADO PARA FISCALIZAÇÃO AUTOMÁTICA DE VEÍCULOS RODOVIÁRIOS DE CARGA}

Tese apresentada ao Departamento de Engenharia Mecânica da Escola de Engenharia de São Carlos da Universidade de São Paulo para obtenção do título de Doutor em Engenharia Mecânica

Área de Concentração: Dinâmica de Máquinas e Sistemas

Orientador: Prof. Dr. Luís Carlos Passarini 
AUTORIZO A REPRODUÇĀO E DIVULGAÇĀO TOTAL OU PARCIAL DESTE TRABALHO, POR QUALQUER MEIO CONVENCIONAL OU ELETRÔNICO, PARA FINS DE ESTUDO E PESQUISA, DESDE QUE CITADA A FONTE.

Ficha catalográfica preparada pela Seçāo de Tratamento da Informação do Serviço de Biblioteca - EESC/USP

\footnotetext{
F363p

Fernandez, Breno Ortega

Proposta de um sistema eletrônico embarcado para

fiscalização automática de veículos rodoviários de carga

/ Breno Ortega Fernandez ; orientador Luís Carlos

Passarini. -- Sāo Carlos, 2010.

Tese (Doutorado-Programa de Pós-Graduaçāo em Engenharia Mecânica e Ärea de Concentração em Dinâmica das Máquinas e Sistemas) -- Escola de Engenharia de Sāo Carlos da Universidade de São Paulo, 2010.

1. Transporte rodoviário. 2. Segurança no trânsito. 3. Acidentes de trânsito. 4. Veículos rodoviários legislaçāo. I. Título.
} 
Nome: FERNANDEZ, Breno Ortega.

Título: PROPOSTA DE UM SISTEMA ELETRÔNICO EMBARCADO PARA

FISCALIZAÇÃO AUTOMÁTICA DE VEÍCULOS RODOVIÁRIOS DE CARGA

Examinado em: 25/11/2010

Banca Examinadora de Defesa

Prof. Dr. Luís Carlos Passarini

EESC-USP

Prof. Dr. Antonio Carlos Canale

EESC-USP

Profa. Dra. Wanda Hoffmann

UFSCAR

Prof. Dr. Leandro Innocentini Lopes de Faria UFSCAR

Prof. Dr. Fábio Moreira da Silva

UFLA 



\section{DEDICATÓRIA}

Este trabalho é integralmente dedicado a quem sempre se dedicou incondicionalmente a mim. Meus pais Luiz Dorival Ortega Fernandez e Ieda Lúcia da S. Fernandez, meus irmãos Enzo Ortega Fernandez e Glauco Ortega Fernandez e a minha esposa Thaís Letícia Miazzo Garcia Ortega.Obrigado Deus pela família maravilhosa com que presenteou-me. 



\section{AGRADECIMENTOS}

O desenvolvimento deste trabalho sofreu a influência positiva de pessoas e organizações dentre as quais rendo especial homenagem:

Ao meu orientador, Prof. Dr. Luís Carlos Passarini, pelos sete anos ininterruptos de paciência e sabedoria com que conduziu a minha orientação. Sua tolerância e profissionalismo foram fundamentais para que eu pudesse galgar os graus de mestre e doutor. Espero, pois, que outras oportunidades de trabalho conjunto possam ainda surgir.

Ao amigo, Prof. Milton Léo, Reitor do Centro Universitário de Lins - UNILINS, na figura de quem agradeço a todo o corpo funcional daquela instituição pela logística, suporte e apoio financeiro para a realização deste trabalho.

Aos colegas do Centro de Informações da FPTE pelo auxílio técnico prestado nas horas críticas de desenvolvimento dos protótipos.

Ao amigo, Eng. Rodrigo Montalvão, e seus colegas da LG Brasil, pelas discussões técnicas de alto nível sobre comunicações sem fio.

Aos discentes, Charles Willian Jardim de Azevedo, Juliano Visoni Barbeiro e Carlos Henrique de Alencar, meus orientados de TCC, pelo inestimável auxílio durante a realização dos ensaios rodoviários.

Ao amigo Cb. Edilberto Davis, na figura de quem agradeço a toda Policia Militar Rodoviária do Estado de São Paulo por todas as facilidades oferecidas durante a realização dos ensaios rodoviários. 
Aos Profs. Antonio Carlos Canale, Wanda Hoffmann, Leandro Innocentini Lopes de

Faria e Fábio Moreira da Silva, por sua disponibilidade em compartilhar do vosso pouco tempo disponível para avaliar o meu trabalho.

Ao meu amigo por acaso, irmão por afinidade, Prof. Hamilton Luiz de Souza, meu grande incentivador profissional e referência pessoal. Desde a graduação seus conselhos têm feito a diferença em minha vida, e não foi diferente neste trabalho.

À minha esposa, Thaís Letícia, pela abdicação da minha atenção durante os anos de desenvolvimento deste trabalho e pelas intermináveis revisões de texto técnico a que eu a submeti.

A todos agradeço, profundamente, e dedico os louros deste trabalho. 


\section{EPÍGRAFE}

$\grave{\mathrm{A}} \therefore \mathrm{G} \therefore \mathrm{D} \therefore \mathrm{G} \therefore \mathrm{A} \therefore \mathrm{D} \therefore \mathrm{U} \therefore$

Lembra-te de teu Criador nos dias de tua mocidade, antes que venham os maus dias e que apareçam os anos em que dirás: "Não tenho neles prazer"; antes que se escureçam o sol, a luz, a lua e as estrelas, e que à chuva sucedam as nuvens; antes que o pó volte à terra, como o era, e o espírito volte à Deus que o deu. Vaidade das vaidades! Diz o pregador, tudo é vaidade.

Eclesiastes 1,2 e 7 . 



\section{RESUMO}

As jornadas de trabalho excessivas são uma dura realidade para os condutores de veículos de carga no Brasil. Exigidos por um sistema de trabalho desleal estes condutores enfrentam ainda as péssimas condições da malha viária e o gargalo provado pelo crescente número de veículos de passeio em circulação. Esse mistura de fatores tem provocado um índice alarmante de acidentes de trânsito, com um número de mortes comparáveis aos de um conflito armado. Neste trabalho é apresentada a proposta de um equipamento registrador instantâneo e inalterável de velocidade e tempo, que combina as funções de um registrador convencional com um eficiente mecanismo de comunicação sem fios, fazendo com que o próprio equipamento reporte às autoridades de transito os excessos de jornada de trabalho dos veículos de carga. A identificação inequívoca do condutor é realizada através de uma estrutura de certificação digital baseada em cartões inteligentes que garante também a privacidade das informações.

Palavras chave: transporte de carga, tacógrafo, segurança no trânsito, acidentes de trânsito, aplicação eletrônica da lei, tempo de condução. 



\begin{abstract}
The excessive hours of service is a harsh reality for drivers of goods vehicles in Brazil. Required by a system of unfair labor these drivers still face the bad conditions of roads and bottleneck proved by the increasing number of passenger cars in circulation. This mix of factors has caused an alarming rate of traffic accidents, with a death toll comparable to an armed conflict. This thesis presents a proposal for an electronic equipment, which combines the functions of a conventional tacograph with an efficient wireless communication system, making a auto reporting system of the driving excesses to the authorities of the transit. The unequivocal identification of the driver is done through a digital certification structure based on smart cards that also ensures the privacy of information.
\end{abstract}

Keywords: cargo transportation, tachograph, traffic safety, traffic accidents, eenforcement, hours of service. 



\section{LISTA DE FIGURAS}

Figura 1-1 - Comparativo Brasil x EUA quanto à composição da matriz de transporte de cargas

Figura 1-2 - Relação entre o número de veículos e o de habitantes no Brasil..........................28

Figura 1-3 - Carga transportada por rodovias no Brasil.

Figura 1-4 - Evolução do número de acidentes por ano em função do tipo de veículo. 30

Figura 1-5 - Acidentes de trânsito com vítimas no Brasil. 31

Figura 2-1 - Painel frontal de um tacógrafo analógico (VDO, 2009).

Figura 2-2 - Disco de registro do RIIVT mecânico (IGT, 2009).

Figura 2-3 - Redutor angular para medida de deslocamento (VDO, 2009).

Figura 2-4 - Sensor indutivo e conversor de pulsos para medida de deslocamento (VDO, 2009). 45

Figura 2-5 - Painel frontal do RIIVT digital SVT-3000A (SEVA, 2001) 46

Figura 2-6 - Panorama mundial da exigência de tacógrafo (LEHMANN, 1999).

Figura 2-7 - Evolução da quilometragem percorrida / número de acidentes na Alemanha (LEHMANN, 1999). 48

Figura 2-8 - Formulário para registro de horas de condução de veículos de carga nos EUA (FMCSA, 2009). 49

Figura 2-9 - Diagrama de blocos da unidade de veículo européia (GRANTURCO, 2007).....51 Figura 2-10 - Diagrama de blocos de um cartão inteligente e sua aparência (WOLFGANG R. E WOLFGANG E., 2002). 52

Figura 2-11 - Órbitas dos satélites do sistema GPS (DANA, 2000). 59

Figura 2-12 - Arranjo de modulação dos sinais GPS (DANA, 2000). 59

Figura 2-13 - Interseção de circunferências no sistema GPS (DANA, 2000). 61 
Figura 2-14 - (a) Posicionamento ideal DOP baixo, (b) Posicionamento ruim DOP alto (DANA, 2000).

Figura 2-15 - Organograma da Autoridade de Certificação Brasileira (CERTISIGN, 2010). 68

Figura 2-16 - Cartão inteligente do e-CPF (CERTISIGN, 2010). 69

Figura 2-17 Diagrama elétrico de etiqueta inteligente (WOLFGANG R. E WOLFGANG E., 2002). 70

Figura 2-18 - Aspecto da etiqueta eletrônica (WOLFGANG R. E WOLFGANG E., 2002). . 70

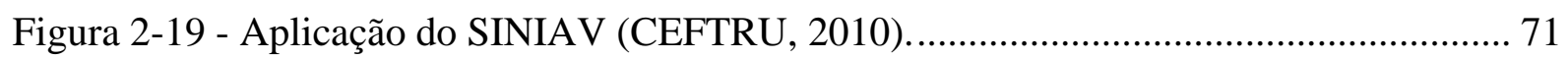

Figura 2-20 - Representação do modelo TCP/IP (TANEMBAUM, 1997). ............................ 74

Figura 2-21 - Organização do projeto IEEE802 (BOWLER, 2010).................................... 76

Figura 2-22 - Primeiras revisões da norma 802.11 (IEEE802, 2010).................................... 77

Figura 2-23 - Descrição dos canais da tecnologia DSRC (INTELIDRIVE, 2009)................ 78

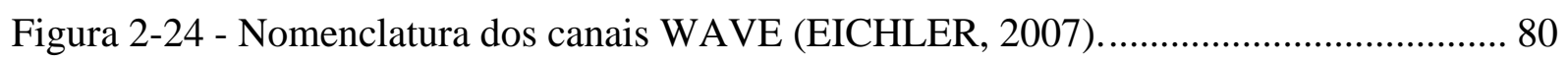

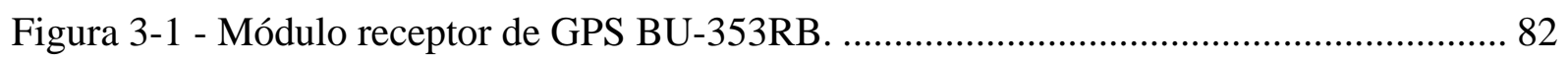

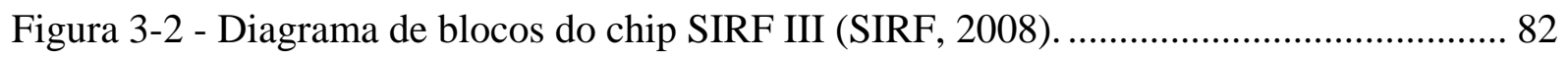

Figura 3-3 - A Carteira Nacional de Habilitação - CNH (DETRAN, 2009). .......................... 84

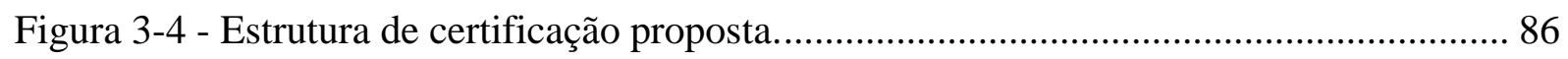

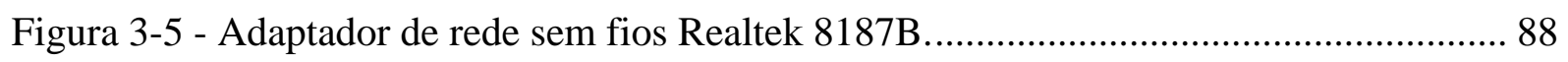

Figura 3-6 - Proposta do sistema de fiscalização sem fios. ................................................. 89

Figura 3-7 - Concepção do sistema central de processamento. ............................................ 90

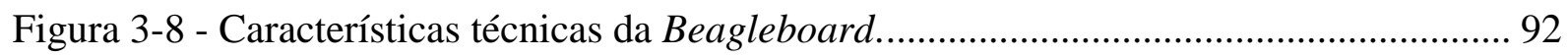

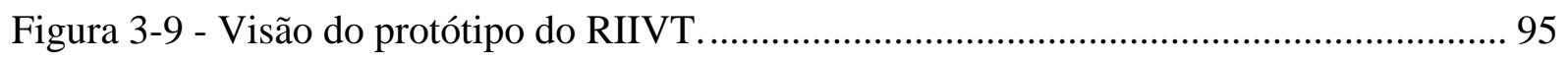

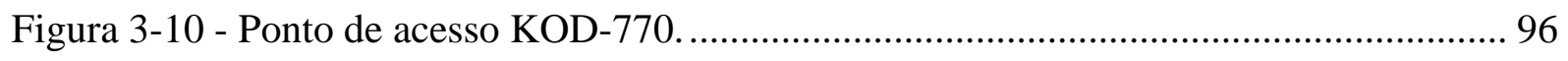

Figura 3-11 - Diagrama de blocos do software do fiscalizador. ......................................... 97

Figura 3-12 - Interface do programa do fiscalizador .................................................... 99 
Figura 3-13 - Diagrama de blocos do programa de comunicação.

Figura 3-14 - Diagrama de blocos do software de registro 102

Figura 3-15 - Diagrama de blocos do programa de análise.

Figura 4-1 - Processo de verificação da acuracidade do receptor GPS. 107

Figura 4-2 - Certificados digitais gerados para teste.

Figura 4-3 - Arquivo de teste digitalmente assinado.

Figura 4-4 - Verificação válida de arquivo digitalmente assinado

Figura 4-5 - Verificação inválida de arquivo digitalmente assinado.

Figura 4-6 - Processo de criptografia e assinatura de arquivos para download.

Figura 4-7 - Vista da rodovia Marechal Rondon no sentido interior-capital.

Figura 4-8 - Localização do ponto de acesso.

Figura 4-9 - Veículo de testes, no detalhe receptor GPS e interface de rede.

Figura 4-10 - Panorama dos pontos de acesso disponíveis no trecho de testes (Elaboração própria feita sobre imagem do serviço GOOGLE EARTH, Acessado em 17/10/2010)

Figura 4-11 - Área de cobertura do ponto de acesso de testes (Elaboração própria feita sobre imagem do serviço GOOGLE EARTH, Acessado em 17/10/2010). 116

Figura 4-12 - Nova localização do ponto de acesso.

Figura 4-13 - Área de cobertura da nova posição do ponto de acesso de testes (Elaboração própria feita sobre imagem do serviço GOOGLE EARTH, Acessado em 17/10/2010)

Figura 4-14 - Comparativo das áreas de cobertura (Elaboração própria feita sobre imagem do serviço GOOGLE EARTH, Acessado em 17/10/2010). 123

Figura 4-15- Gráfico da velocidade do veículo x quantidade de bytes transferidos. 124 


\section{LISTA DE TABELAS}

Tabela 2-1 - Mapa de memória da placa eletrônica do SINIAV.

Tabela 2-2 - Requisitos necessários a uma tecnologia de comunicação automotiva. 77

Tabela 2-3 - Comparativo das tecnologias de comunicação veicular. 80

Tabela 4-1 - Resultados do primeiro teste de passagem. 117

Tabela 4-2 - Resultados do segundo teste de passagem. 122

Tabela 4-3 - Estimativa dos custos do projeto. 125 


\section{LISTA DE EQUAÇÕES}

Equação 4-1 - Distância Geográfica . 


\section{LISTA DE ABREVIATURAS E SIGLAS}

\begin{tabular}{|c|c|}
\hline$A / D$ & - Analog to Digital \\
\hline ABRAMET & - Associação Brasileira de Medicina de Tráfego \\
\hline ABS & - Anti-lock Braking System \\
\hline$A C$ & - Autoridade Certificadora \\
\hline AC Raiz & - Autoridade Certificadora Raiz \\
\hline AETR & $\begin{array}{l}\text { European Agreement Concerning the Work of Crews of Vehicles Engaged in } \\
\text { International Road Transport }\end{array}$ \\
\hline ANTT & - Agência Nacional de Transporte Terrestre \\
\hline$A R$ & - Autoridades de Registro \\
\hline ASCII & - American Standard Code for Information Interchange \\
\hline bps & - Bits por segundo \\
\hline BTS & - Bureau of Transportation Statistics \\
\hline CA & - Certification Authority \\
\hline CAN & - Control Area Network \\
\hline CEL & - Centro de Estudos em Logística \\
\hline CGS & - Centímetro - Grama - Segundo, sistema de medidas \\
\hline $\mathrm{CNH}$ & - Carteira Nacional de Habilitação \\
\hline CNT & - Confederação Nacional do Transporte \\
\hline CONTRAN & - Conselho Nacional de Trânsito \\
\hline CP'S & - Component Pesonalizers \\
\hline CPF & - Cadastro de Pessoa Física \\
\hline CPU & - Central Processing Unit \\
\hline СТВ & - Código de Trânsito Brasileiro \\
\hline CVC & - Composição de Veículo de Carga \\
\hline $\mathrm{DC} / \mathrm{DC}$ & - Direct Current to Direct Current \\
\hline DDR & - Double Data Rate \\
\hline DENATRAN & - Departamento Nacional de Trânsito \\
\hline DNIT & - Departamento Nacional de Infra-estrutura de Transportes \\
\hline DSRC & - Dedicated Short Range Communications \\
\hline e-CNPJ & - Cadastro de Pessoa Jurídica eletrônico \\
\hline e-CPF & - Cadastro de Pessoa Física eletrônico \\
\hline EDR & - Event Data Recorders \\
\hline EOBR & - Electronic On-Board Recorders \\
\hline ERCA & - European Root Certification Authority \\
\hline ESSID & - Extended Service Set Identifier \\
\hline EUA & - Estados Unidos da América \\
\hline FCC & - Federal Communication Comission \\
\hline FIPE & - Fundação Instituto de Pesquisas Econômicas \\
\hline FMSCA & - Federal Motor Carrier Safety Administration \\
\hline GB & - Giga Bytes \\
\hline GMT & - Greenwich Mean Time \\
\hline GPS & - Global Positioning System - Sistema de Posicionamento Global \\
\hline GSM & - Global System for Mobile communications \\
\hline HOS & - Hours of Service \\
\hline I/O & - Input and Output \\
\hline
\end{tabular}




\begin{tabular}{|c|c|}
\hline IBGE & - Instituto Brasileiro de Geografia e Estatística \\
\hline ICP & - Infra-estrutura de Chave Pública \\
\hline IEEE & - Institute of Electrical and Electronic Engineers \\
\hline IGT & - Inspecção Geral do Trabalho \\
\hline INMETRO & - Instituto Nacional de Metrologia. \\
\hline IPEA & - Instituto de Pesquisas Econômicas Aplicadas \\
\hline ISM & - Industrial Scientific and Medical \\
\hline ITS & - Intelligent Transportation Systems \\
\hline IVC & - Inter-vehicle Communication \\
\hline KDM & - Key Distribution Message \\
\hline KDR & - Key Distribution Request \\
\hline $\mathrm{Km} / \mathrm{h}$ & - Quilômetros por hora \\
\hline KmVU & - Key master Veicular Unit \\
\hline KmWC & - Key master Workshop Card \\
\hline LMS & - Location and Monitoring Services \\
\hline MB & - Mega Bytes \\
\hline Mbps & - Mega bits por segundo \\
\hline MEMS & - Microelectromechanical systems \\
\hline NCA'S & - National Certification Authoritys \\
\hline NMEA & - National Marine Electronics Association \\
\hline NTC & - National Transport Comission \\
\hline NTP & - Network Time Protocol \\
\hline ONU & - Organização das Nações Unidas \\
\hline PC & - Personal Computer \\
\hline PIB & - Produto Interno Bruto \\
\hline PSD & - Power Spectrum Density \\
\hline RAM & - Random Access Memory \\
\hline RENAEST & - Registro Nacional de Acidentes e Estatísticas de Trânsito \\
\hline RG & - Registro Geral \\
\hline RIC & - Registro de Identidade Civil \\
\hline RIIVT & - Registrador Instantâneo e Inalterável de Velocidade e Tempo \\
\hline ROM & - Ready Only Memory \\
\hline RSA & - Rivest, Shamir Adleman, inventores da técnica de criptografia RSA \\
\hline RVC & - Road Vehicle Communication \\
\hline SD & - Secure Digital \\
\hline SI & - Sistema Internacional de medidas \\
\hline SINIAV & - Sistema Nacional de Identificação Automática de Veículos \\
\hline SQL & - Structured Query Language \\
\hline TachoNET & - Tachograph Network \\
\hline $\mathrm{TI}$ & - Tecnologia da Informação \\
\hline URN & - Unique Reference Number \\
\hline USB & - Universal Serial Bus \\
\hline UTC & - Universal Time Coordinated \\
\hline VANETS & - Vehicular ad-hoc Networks \\
\hline VERONICA & - Vehicle Event Recording based On Intelligent Crash Assessment \\
\hline VU & - Vehicle Unit \\
\hline WAVE & - Wireless Access in Vehicular Environments \\
\hline
\end{tabular}




\section{SUMÁRIO}

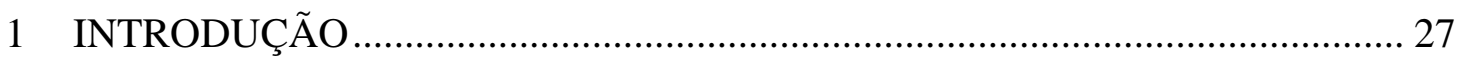

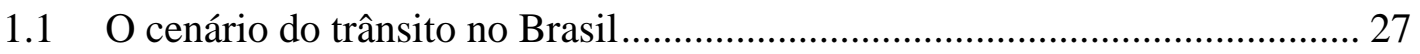

1.2 Os acidentes de trânsito no Brasil ............................................................... 29

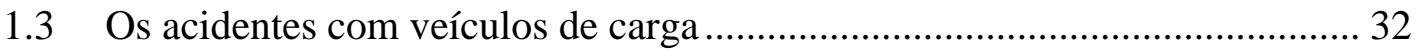

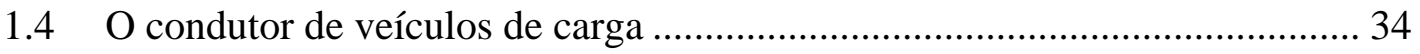

1.5 A fiscalização do setor de transporte de cargas............................................. 35

1.6 A proposta da pesquisa e objetivos ........................................................ 36

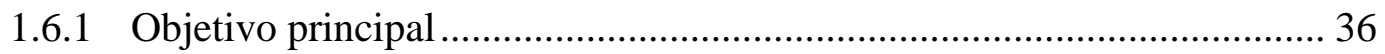

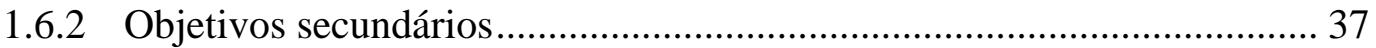

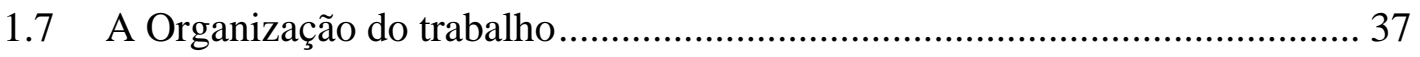

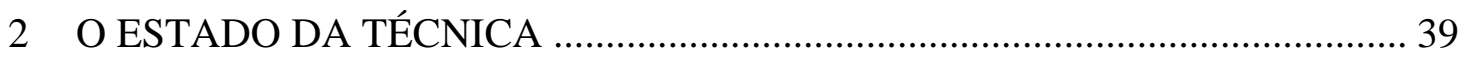

2.1 O registrador instantâneo e inalterável de velocidade e tempo ....................... 39

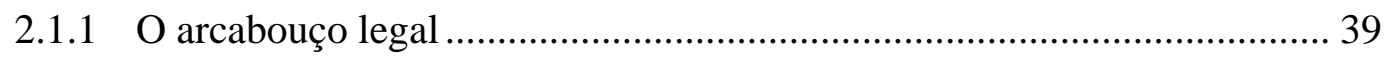

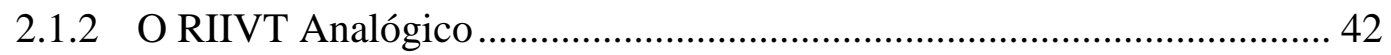

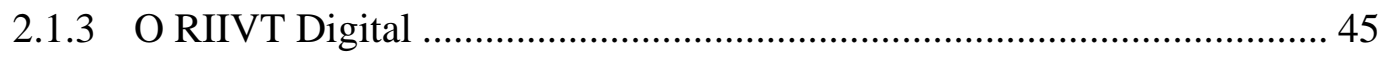

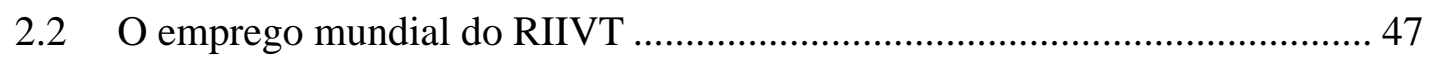

2.3 O tacógrafo digital da comunidade européia .......................................... 50

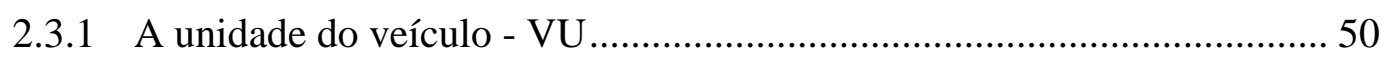

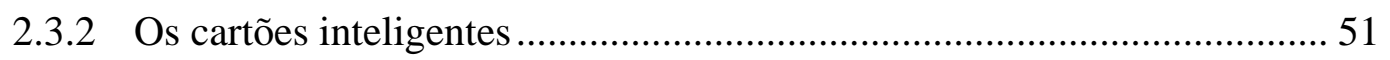

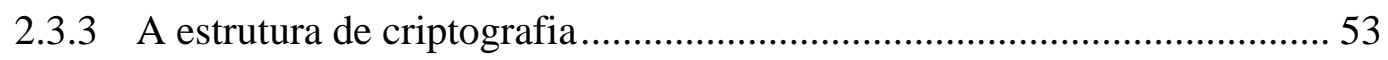

2.4 Alternativas para a medida de deslocamento e direção de veículos............... 55 
2.5.1 Os erros de posicionamento no sistema GPS 61

2.6 Iniciativas pertinentes 62

2.7 A aplicação eletrônica da lei - e-enforcement 64

2.8 Os certificados digitais 65

2.8.1 A estrutura de certificação digital no Brasil 66

2.8.2 O e-CPF - Cadastro de Pessoa Física eletrônico 68

2.9 O Sistema nacional de identificação automática de veículos - SINIAV 69

2.10 Tecnologias para conexões sem fios 73

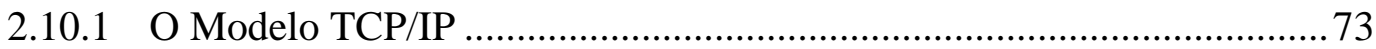

2.10.2 Os padrões de rede IEEE …........................................................ 75

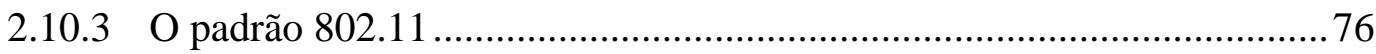

2.10.4 Aplicações automotivas das redes sem fios ......................................... 77

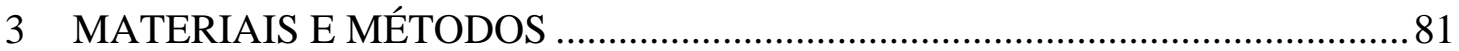

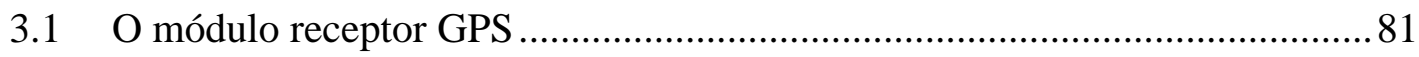

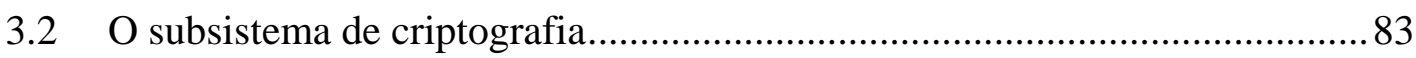

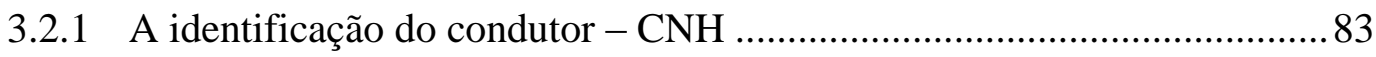

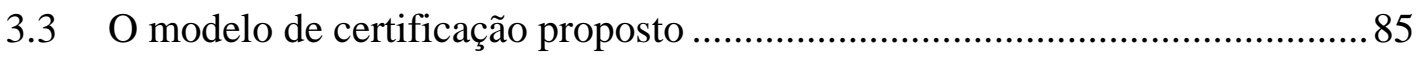

3.4 O subsistema de comunicação sem fios ....................................................... 87

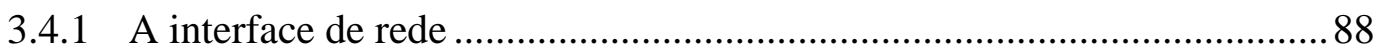

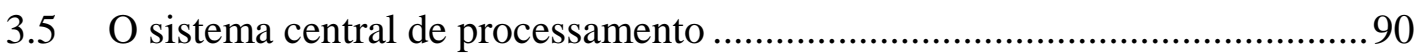

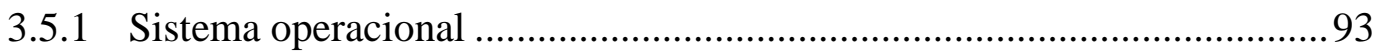


3.5.3 O relógio do sistema

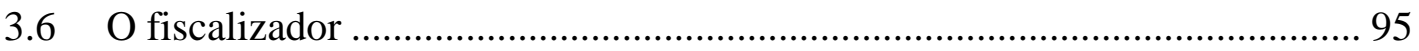

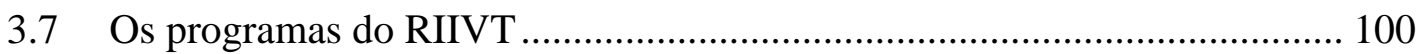

3.7.1 O programa de comunicação ............................................................... 100

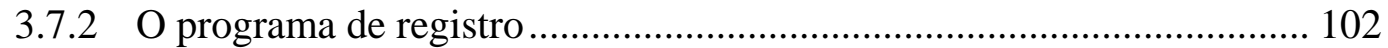

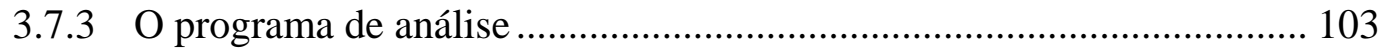

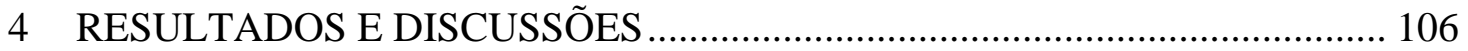

4.1 Condições de ensaio para a validação dos subsistemas ............................... 106

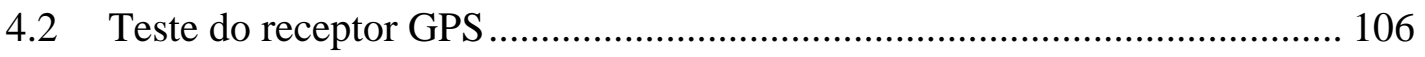

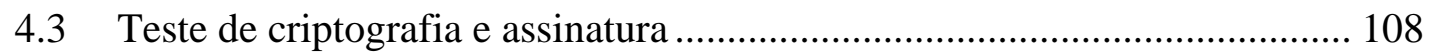

4.4 Testes da conexão de rede sem fios............................................................ 111

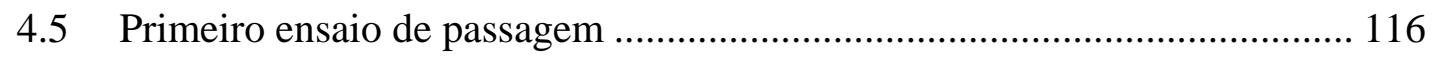

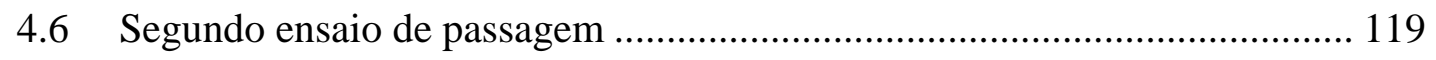

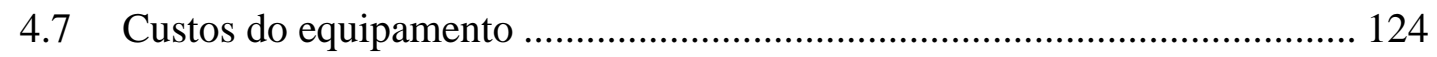

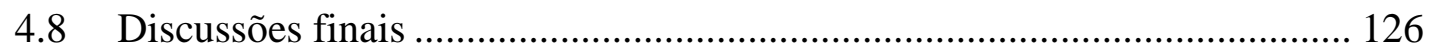

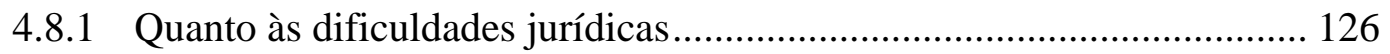

4.8.2 Quanto às dificuldades técnicas............................................................. 127

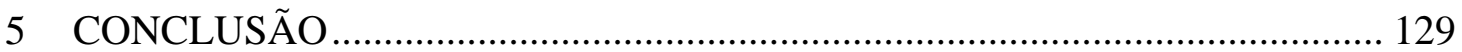

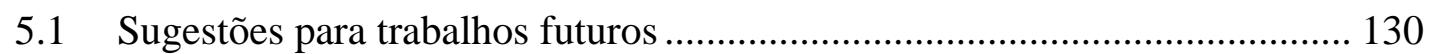

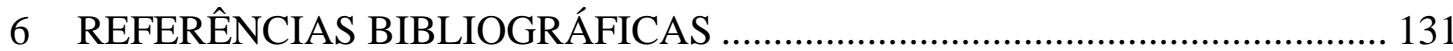




\section{INTRODUÇÃO}

\subsection{O cenário do trânsito no Brasil}

O Brasil é um país de dimensões continentais que compreende uma área superior a 8,5 milhões de quilômetros quadrados e com uma população estimada em mais de 190 milhões de pessoas (IBGE, 2002,2009).

Todo o esforço para o transporte de cargas no território é distribuído entre os diferentes meios disponíveis na infraestrutura nacional. A essa estrutura dá-se o nome de matriz de transporte de cargas. A distribuição da matriz brasileira pode ser vista no gráfico da Figura 1-1 (ANTT, 2007). No mesmo gráfico é apresentada a matriz de transporte de cargas dos EUA para fins de comparação (BTS, 2002).

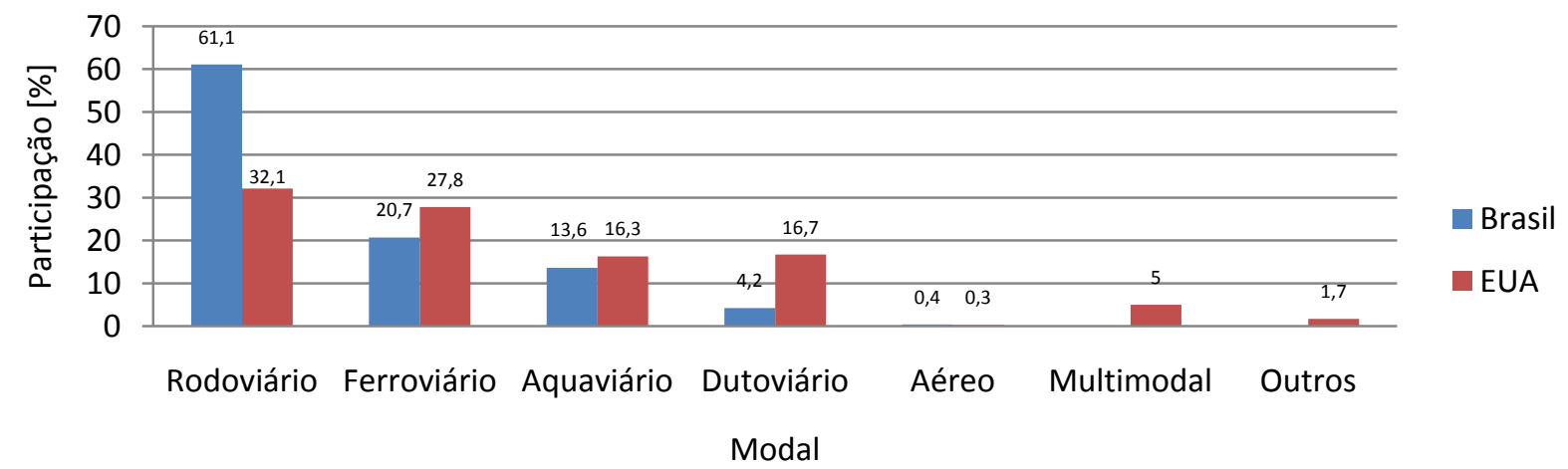

Figura 1-1 - Comparativo Brasil x EUA quanto à composição da matriz de transporte de cargas. 
Pode-se observar no gráfico que a matriz de transporte de cargas no país é fortemente dependente do transporte rodoviário, em detrimento dos demais meios de transporte. Segundo o Guia do Transportador (2009), excluindo-se desses números apenas a massa de minério de ferro que é transportada em ferrovias operadas pelas próprias mineradoras, a participação rodoviária na matriz de transporte nacional sobe para $82,1 \%$. Fica claro então que alterações de qualquer ordem no sistema nacional de trânsito podem produzir interferências complexas no transporte de cargas do país.

Concomitante a este desbalanceamento da matriz de transporte o Brasil tem experimentado um crescimento econômico nos últimos dez anos que colocou o país em posição de destaque no cenário econômico mundial, fortalecendo a indústria, gerando empregos e aquecendo o comércio interno. Desse processo de desenvolvimento econômico resultaram alterações sensíveis no cenário de trânsito nacional. A maior delas foi o aumento substancial no número de veículos registrados em circulação no país saltando dos 29.503 .503 consolidados no ano 2000 para 58.506.136 em outubro de 2009, num incremento de $98 \%$ em menos de nove anos (DENATRAN, 2009). O gráfico da Figura 1-2 apresenta a relação entre o número de veículos registrados e o número de habitantes no país, mostrando que a quantidade de veículos no país cresce a uma taxa superior a população (IBGE, 2009 e DENATRAN, 2009).

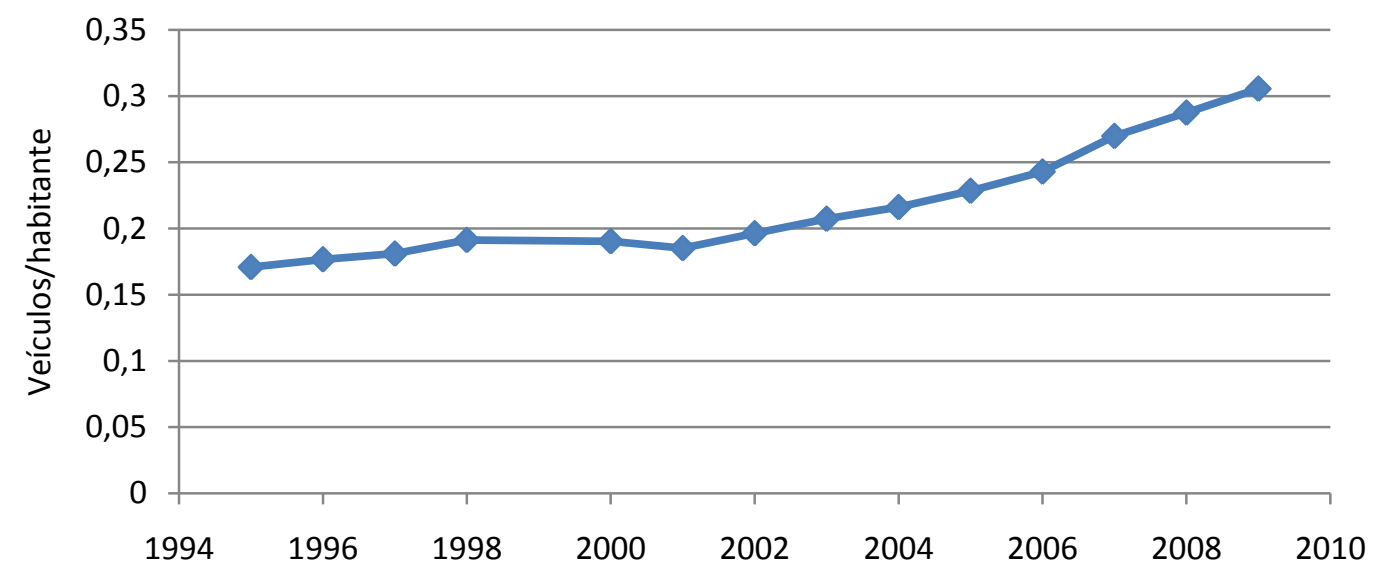

Figura 1-2 - Relação entre o número de veículos e o de habitantes no Brasil. 
Outro fato importante é que aparentemente esse crescimento da frota nacional não produziu incremento na quantidade de carga transportada. Segundo dados estimados pela FIPE - Fundação Instituto de Pesquisas Econômicas, a partir de 2006, a massa de carga rodoviária transportada têm se mantido aproximadamente constante como pode ser visto no gráfico da Figura 1-3 (FIPE, 2009).

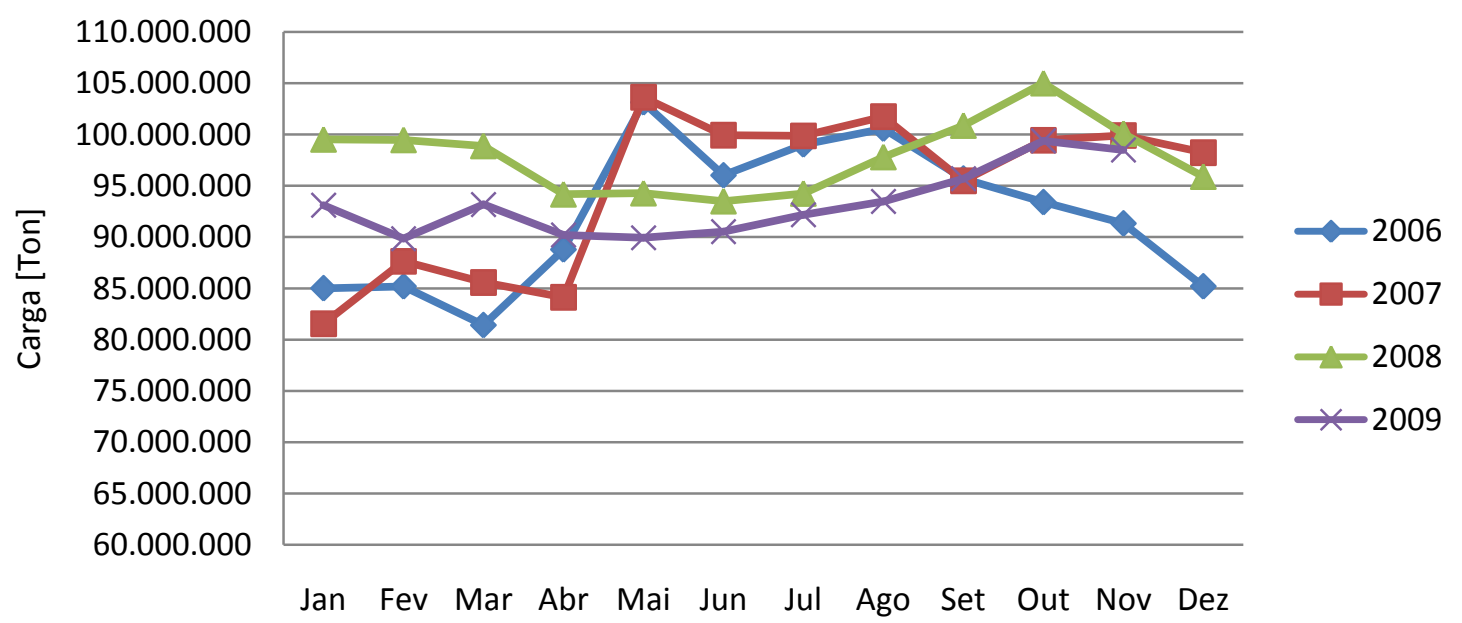

Figura 1-3 - Carga transportada por rodovias no Brasil.

Se existem então aproximadamente duas vezes mais veículos em circulação que há uma década, e se neste mesmo período a malha viária asfaltada do país cresceu apenas 7,95\% (CNT, 2005, 2009), é natural esperar pelo surgimento de problemas decorrentes do excesso de veículos no sistema nacional de trânsito. Também é claro que esses problemas trarão consequências ao país, dentre as quais a mais relevante a este estudo é o incremento do número de acidentes de trânsito.

\subsection{Os acidentes de trânsito no Brasil}

O acidente de trânsito é tecnicamente definido pelo ministério da saúde (BRASIL, 2001) como:

“[...] o evento não intencional e evitável, causador de lesões físicas e ou emocionais no âmbito doméstico ou nos outros ambientes sociais, como o do trabalho, do trânsito, [...] Assume-se, aqui, que tais eventos são, em maior ou menor grau, perfeitamente previsíveis e preveníeis". 
Na prática, os acidentes de trânsito, quaisquer que sejam as suas circunstâncias, são sempre experiências difíceis e traumatizantes para os envolvidos, suas famílias e a sociedade de forma geral. Além disso, desencadeia um dispendioso processo que vai do resgate a vitimas até a reabilitação física dos que sofrem lesões graves ou até mesmo a assistência aos permanentemente inválidos, que onera o Estado provocando a aspersão de recursos e tão somente remediando as consequências do acidente.

O CONTRAN - Conselho Nacional de Trânsito, por meio da resolução No 208 de 26 de outubro de 2006, instituiu o RENAEST, sistema de registro, gestão e controle de dados estatísticos sobre acidentalidade no trânsito, ligado ao DENATRAN, com a finalidade de colaborar com o desenvolvimento de políticas públicas para redução destes. Consultando-se essa base de dados estatísticos, (DENATRAN, 1999, 2000, 2001, 2002, 2003, 2004, 2005, 2006 e 2007), pode-se traçar um perfil do número de acidentes de trânsito com vítima, registrados no país em função do tipo de veículo envolvido, para os anos de 1999 a 2007.

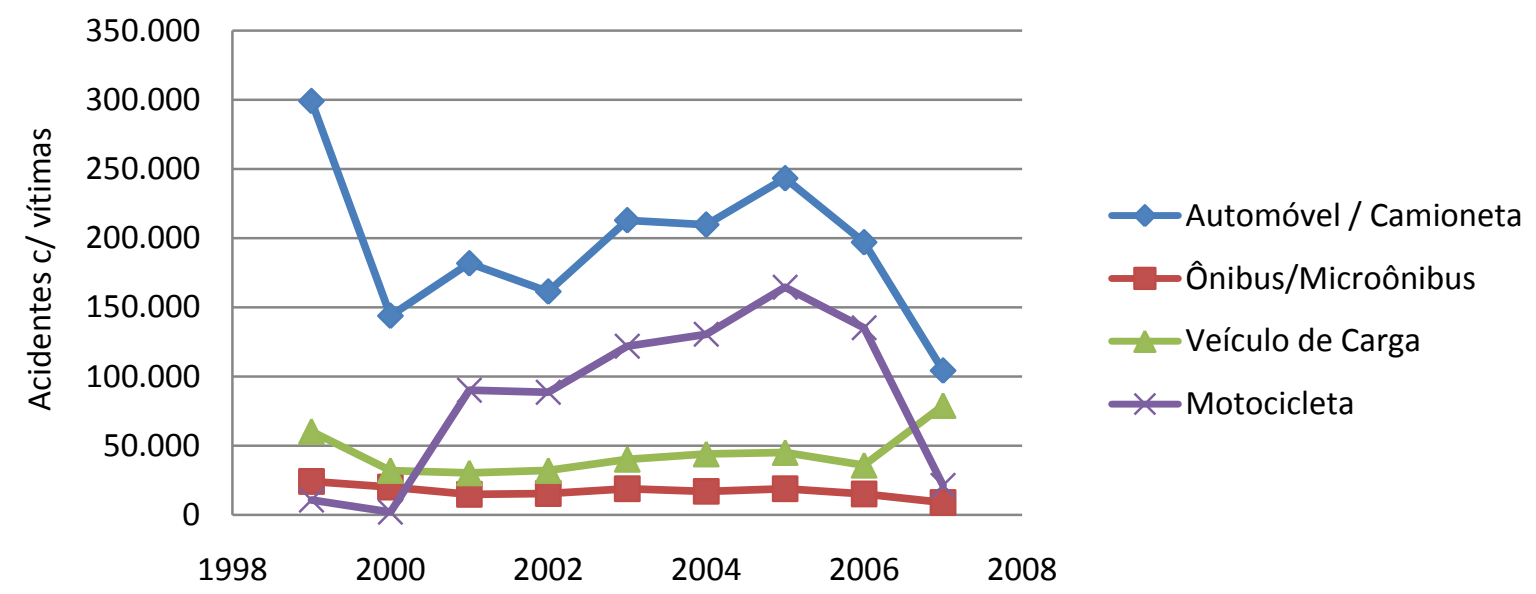

Figura 1-4 - Evolução do número de acidentes por ano em função do tipo de veículo.

Observa-se na Figura 1-4 que a partir do ano de 2005 o número de acidentes com vítimas no país vem caindo gradativamente, exceto os acidentes com veículos de carga que a partir de 2006 voltou a crescer. 
Koizumi e Jorge (2007), em estudo publicado pela ABRAMET - Associação Brasileira de Medicina de Tráfego contabilizaram o número de vítimas destes acidentes em igual período. Este estudo afirma que os números de vítimas e de óbitos vêm crescendo ano a ano, mesmo com a queda do número de acidentes com vítimas. O gráfico da Figura 1-5 exibe os números relatados por Koizumi e Jorge (2007).

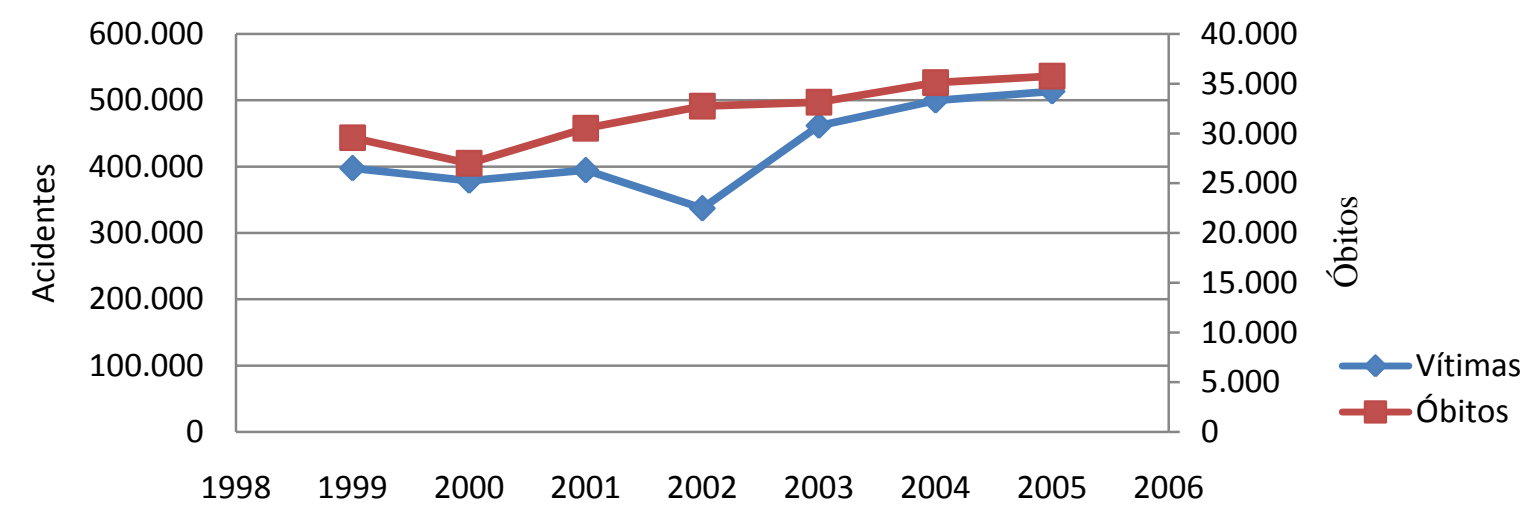

Figura 1-5 - Acidentes de trânsito com vítimas no Brasil.

Ressalte-se que o número de óbitos tem obedecido a uma preocupante tendência ascendente, sustentando uma taxa média de 3,4\% ao ano. Além disso, Koizumi e Jorge (2007) observam que, dentre o número de óbitos, $70 \%$ deles ocorreram ainda no local do acidente o que aliado às observações anteriores, reforça a evidência de que os acidentes estão adquirindo proporções cada vez mais graves.

Visando quantificar o impacto financeiro dos acidentes de trânsito ao país, o IPEA Instituto de Pesquisas Econômicas Aplicadas elaborou um modelo que correlaciona todas as despesas financeiras envolvidas em um acidente de trânsito com vítimas, aplicando-se em seguida esse modelo aos dados estatísticos de acidentes nas rodovias federais para o ano de 2005. Ao final deste, o IPEA (2006) afirma que:

"Os custos dos acidentes nas rodovias federais relativos às pessoas representam $68,5 \%$ do total - este igual a 6,5 bilhões de reais, a preços de dezembro de 2005 -, seguidos dos custos relativos aos veículos $(31,1 \%)$. Os demais custos $(0,4 \%)$ são aqueles decorrentes dos danos à propriedade pública e privada (sem os veículos, é claro) e os custos de atendimento do acidente." 
Mais adiante o estudo esclarece que "Os custos médios dos acidentes são fortemente influenciados pela sua gravidade. Um ileso adiciona ao acidente um custo médio de $\mathrm{R} \$ 1.207$; uma vítima classificada pela polícia rodoviária como ferida adiciona $\mathrm{R} \$ 38.256$; e um morto, $\mathrm{R} \$ 281.216 . ”$.

Desta feita o IPEA demonstra que, apenas em 2005, as consequências dos acidentes de trânsito custaram ao contribuinte brasileiro um valor estimado em $\mathrm{R} \$ 6.512 .085 .050,00$, com uma margem de erro de $3,7 \%$ para mais ou para menos. Este valor equivale a aproximadamente $0,3 \%$ do PIB - Produto Interno Bruto do país para o mesmo ano (IBGE, 2007). Confrontando-se estes números com os publicados em relatório da CNT Confederação Nacional do Transporte, constata-se que o país gasta mais com as consequências dos acidentes de trânsito do que com investimentos na modernização da malha viária, que em 2008 ficou em apenas 0,22\% do PIB (CNT, 2009).

\subsection{Os acidentes com veículos de carga}

Voltando ao gráfico da Figura 1-4, nota-se que a tendência descendente do número de acidentes sofre uma inversão no ano de 2007 , de forma que em 36,4\% dos acidentes com vítimas no país estavam envolvidos veículos de carga.

Pesquisa do CEL - Centro de Estudos em Logística revela que no ano de 2005, em 85\% dos acidentes ocorridos com veículos de carga a pista estava em boas condições de tráfego, em $81 \%$ as condições climáticas estavam boas, sendo que a falha humana foi apontada como causa do acidente em 66\% dos casos (CEL, 2006). Note-se então que dois terços dos acidentes com veículos de carga no país em 2005 devem-se a falha humana, atacando o senso comum de que o mal estado de conservação das rodovias brasileiras seja o grande vilão dos acidentes de trânsito. Aparentemente, a má conservação das vias produz 
mais impactos financeiros por danos aos veículos e entraves às cadeias logísticas devido aos atrasos daí decorrentes.

Depois da falha humana, as causas mais apontadas para os acidentes envolvendo transporte de carga são as características da via com $47 \%$ e o defeito mecânico com $11 \%$. A imprudência com $43 \%$ é a principal causa dos erros humanos ao volante. Entre os motoristas envolvidos em acidentes, 57\% disseram estar em velocidade incompatível (CEL, 2006).

Parte dos acidentes que foram atribuídos às características da via podem ser explicados pela inadequação da mesma para comportar os modernos veículos de transporte de cargas.

O CVC - Conjunto de Veículos de Carga foi instituído em 1998 pela resolução 68/98 do CONTRAN e posteriormente alterado pela resolução 184/2005, e trata do agrupamento de até quatro veículos de carga sendo um deles a unidade de tração. Segundo Mattos e Albano (2007), o uso dos CVC’s tem crescido rapidamente após a sua regulamentação. Em 1999 eram 3.530 CVS's registrados, passando para 36.412 em 2004 e saltando para mais de cem mil CVC's registrados em 2006. Mattos e Albano (2007) esclarecem, ainda, que as normas para construção de rodovias publicadas pelo DNIT - Departamento Nacional de Infraestrutura de Trânsito não contemplam o tráfego deste tipo de veículo que transporta mais carga e por seu comprimento provoca alterações nas ultrapassagens, nas interseções em nível e no raio das curvas.

Além disso, Barbieri R. e Barbieri N. (2006) relatam que os CVC's possuem um problema inerente ao seu número de articulações chamado amplificação traseira:

\footnotetext{
"Esse fenômeno faz com que o movimento do cavalo-mecânico seja amplificado na última carreta, podendo provocar o seu tombamento, levando consigo todo o conjunto. Ele ocorre nas curvas ou quando o motorista efetua uma manobra rápida para desviar de um obstáculo”.
}

Como agravante Barbieri R. e Barbieri N. (2006) alertam para o fato de não haver instrução específica na forma de habilitar condutores para conduzir este tipo de veículo. 
Assim sendo o portador de uma habilitação categoria "E" está legalmente preparado para conduzir um CVC com nove eixos, três articulações e um peso bruto total de 74 toneladas.

Essas observações fazem com que as atenções voltem-se novamente para o comportamento do condutor.

\section{$1.4 O$ condutor de veículos de carga}

Koller et al. (2004) assim traçaram o perfil do condutor de veículos de carga no Brasil: 64,4\% são brancos e tem em média 38 anos de idade. $69 \%$ são casados ou vivem em união estável e $70 \%$ têm filhos. A renda mensal fica entre $\mathrm{R} \$ 1.001,00$ e $\mathrm{R} \$ 2.000,00$, e 32,8\% possuem o ensino fundamental incompleto. Apenas 2,5\% possuem algum tipo de ensino superior. Seu trabalho os deixa fora de casa durante 20,3 dias por mês, em média.

Com relação à jornada, Rizzotto (2004) afirma que 51,5\% dos trabalhadores conduzem seus veículos por períodos de 13 a 19 horas por dia, 29\% trabalham de 9 a 12 horas e 10,4\% desenvolvem carga de trabalho superior a 20 horas de trabalho diárias. Ou seja, aproximadamente $90 \%$ dos condutores de veículo de carga no país exercem suas atividades em jornadas cuja duração, segundo Mello (2010), aumenta em até três vezes o risco de acidentes quando comparados àqueles inerentes a uma jornada de trabalho de 8 horas diárias.

Tais dados mostram a difícil situação vivida pelos condutores de veículos de carga enquanto chefes de família e profissionais no Brasil. A lei que regularia a jornada de trabalho destes profissionais ficou em pauta no congresso nacional por mais de 13 anos, e quando aprovada estava tão descaracterizada em relação à proposta técnica original que terminou não sancionada pela Presidência da República por não ser exequível.

Aliado a isso, as grandes empresas de transporte estão mudando o modelo de negócio e transformando-se em empresas de logística. Neste movimento essas empresas têm desmobilizado sua infraestrutura de transporte substituindo-a pela contratação de 
transportadores autônomos que assumem todos os encargos legais e trabalhistas. Desta feita os transportadores autônomos que optam por trabalhar de maneira legalizada encontram uma série de encargos financeiros e legais que por vezes não podem cumprir, além de enfrentar a concorrência desleal dos que optaram pela informalidade.

E mais, segundo Rizzotto (2004) os condutores se vêem ainda reféns de um "sistema de remuneração baseado exclusivamente em produtividade", "que os incentiva a dirigir o mais velozmente possível”, e por períodos incompatíveis com uma jornada aceitável de trabalho. Verifica-se então que os indicadores da quantidade de acidentes de trânsito em decorrência de falhas humanas não estão errados. Pais de família de pouca instrução sendo submetidos a jornadas de trabalho incompatíveis com a sua função, conduzindo veículos com cargas de muitas toneladas por vias sem a mínima manutenção técnica necessária, e com respaldo legal que justifica isso tudo. Estes são os ingredientes do explosivo sistema de transporte de cargas no país.

Sendo assim, é razoável esperar que as estatísticas de acidentes de trânsito com mortes, em especial os envolvendo veículos de carga, continuem subindo no país. Atuar na educação dos condutores de veículos poderá obter efeito nestas estatísticas, mas levará tempo, pois uma cultura de condutores conscientes não se forma sem muitos anos de trabalho.

\subsection{A fiscalização do setor de transporte de cargas}

Pelo exposto, acredita-se que a solução para a diminuição imediata de mortes no trânsito, em especial nos acidentes com veículos de carga, passa pela forte regulamentação do setor acompanhado do aumento da fiscalização para coibir e punir as irregularidades.

O próprio DNIT (BRASIL, 2004) aponta medidas que deveriam ser adotadas pelo governo a fim de minorar o problema de acidentes de trânsito. Dentre eles citam-se: 
“Criação de um programa de monitoramento permanente do desempenho viário, de pesagem e da velocidade, a partir do cálculo dos limites de velocidade em locais críticos; Implementação de Arquiteturas ITS $^{1}$, voltadas para atendimento ao usuário e gerência de incidentes; Melhoria de padrão dos Projetos Finais de Engenharia, com geometria e sinalização/dispositivos de segurança adequados às diferentes classes de rodovia; Estudos da interação entre a via e Combinações de Veículos de Carga, para revisão de normas de circulação e de projetos de Engenharia; Reaparelhamento e treinamento de agentes de operação, para que atuem na fiscalização e controle de veículos irregulares."

A CNT (2002) por sua vez afirma que:

“O transporte rodoviário de carga, com suas inúmeras possibilidades de origens e destinos e também de prestadores de serviços, é aquele em que se verifica a maior dificuldade de fiscalização. Neste modal as verificações relacionadas a excesso de peso, excesso de velocidade, sonegação fiscal, dentre outras, tornam-se de difícil execução. [...] A alocação insuficiente de recursos pelas autoridades responsáveis tem inviabilizado uma fiscalização adequada neste modal."

Em suma, o aumento da fiscalização demanda o aumento do efetivo policial no país, seja ele das esferas estaduais ou federais. Sabe-se que no Brasil este processo de contratação de funcionários públicos depende mais de vontade política do que de fatores que técnicos. Além disso, um aumento do efetivo deve ser acompanhado do respectivo aparelhamento e treinamento dos profissionais o que incorre em mais custos.

Outro fator que fragiliza o processo de fiscalização de trânsito é a corrupção. Foge ao escopo deste trabalho discutir as causas dessa cultura que atinge diversas esferas do poder público e privado no país, mas é fato que os seres humanos são corruptíveis e qualquer operação de fiscalização executada por humanos é passível de corrupção.

\subsection{A proposta da pesquisa e objetivos}

\subsubsection{Objetivo principal}

O objetivo principal desta pesquisa é a de propor um sistema eletrônico embarcado, que integre as funções previstas em lei de um registrador instantâneo e inalterável de velocidade e tempo. Este mesmo equipamento deverá, através de um processo de comunicação sem fios, reportar irregularidades no tempo de condução do veículo, a um

\footnotetext{
${ }^{1}$ ITS = Intelligent Transportation Systems
} 
sistema informatizado central cujos receptores estejam instalados em pontos estratégicos nas estradas, ou em viaturas policiais que podem, inclusive, estar em movimento.

Pretende-se com isso salvaguardar, o condutor dos veículos de carga de regimes de trabalho abusivos, produzindo como conseqüência direta a redução do número de acidentes de transito daí decorrentes. Beneficiando desta forma toda a sociedade de trânsito.

\subsubsection{Objetivos secundários}

Além da realização de ensaios para validar o objetivo principal, espera-se:

- Que o custo de desenvolvimento do protótipo fique abaixo do valor de mercado de um registrador instantâneo e inalterável de velocidade e tempo convencional;

- A infra-estrutura de comunicação sem fios deverá fazer uso de equipamentos normatizados, evitando ao máximo o desenvolvimento de novos protocolos e serviços de rede;

- O sistema proposto não poderá impor incompatibilidades os sistemas SINIAV

- Sistema Nacional de Identificação Automática de Veículos, com o RIC Registro de Identidade Civil, permitindo a obtenção de dados do veículo sem a necessidade de abordagem.

- A privacidade e autenticidade das informações enviadas pelo veículo deverão ser garantidas pelo emprego de algoritmos de criptografia forte.

\subsection{A Organização do trabalho}

No Capitulo 2 são apresentadas as obrigações impostas pela legislação de trânsito em vigor seguido de uma descrição do estado da arte das tecnologias envolvidas. No Capítulo 3 estão descritos os materiais empregados na concepção deste projeto, e as justificativas de sua 
adoção. O Capitulo 4 demonstra os resultados experimentais realizados a fim de comprovar o funcionamento adequado, ou não, das funcionalidades e do sistema como um todo. Conclui-se este trabalho com o Capítulo 5 onde são apresentadas as conclusões e considerações finais. 


\section{O ESTADO DA TÉCNICA}

\subsection{O registrador instantâneo e inalterável de velocidade e tempo}

\subsubsection{O arcabouço legal}

A fim de fiscalizar a jornada de trabalho dos condutores de veículos de carga, bem como identificar possíveis causas envolvendo estes veículos, o governo Brasileiro institui no CTB - Código de Trânsito Brasileiro a obrigatoriedade do uso do registrador inalterável de velocidade e tempo. Popularmente conhecido como tacógrafo ou cronotacógrafo, o equipamento doravante será chamado de RIIVT $^{2}$.

$\mathrm{O}$ artigo 105 do CTB estabelece, entre outros definidos pelo CONTRAN, os equipamentos de uso obrigatório em veículos no país (BRASIL, 1997). Especificamente no item II do referido artigo temos:

"para os veículos de transporte e de condução escolar, os de transporte de
passageiros com mais de dez lugares e os de carga com peso bruto total superior a
quatro mil, quinhentos e trinta e seis quilogramas, equipamento registrador
instantâneo inalterável de velocidade e tempo".

Coube ao CONTRAN - Conselho Nacional de Trânsito a regulamentação do uso dos equipamentos obrigatórios que através da resolução $\mathrm{N}^{\circ}$ 14, (BRASIL, 1998), alterou a

\footnotetext{
${ }^{2}$ RIIVT - Registrador Instantâneo e Inalterável de Velocidade e Tempo.
} 
obrigatoriedade para: "veículos de transporte e condução de escolares, nos de transporte de passageiros com mais de dez lugares e nos de carga com capacidade máxima de tração superior a 19 toneladas". Já a resolução No 87, (BRASIL, 1999), fixou prazo máximo para adequação as normas dos veículos em circulação, e liberou da obrigatoriedade imposta pela CTB os modelos de veículos com data de fabricação até 31 de dezembro de 1990 cuja capacidade máxima de tração seja inferior a 19 toneladas.

A resolução N $^{\circ}$ 92, (BRASIL, 1999), estabeleceu os requisitos técnicos mínimos do RIIVT. O RIIVT “pode constituir-se num único aparelho mecânico, eletrônico ou compor um conjunto computadorizado que, além das funções específicas, exerça outros controles”. Esta diretiva fornece o respaldo legal a este projeto, com a ressalva de atender aos demais requisitos técnicos. Além disso, o conjunto RIIVT deverá exibir a qualquer momento as seguintes informações:

"relativas às últimas vinte e quatro horas de operação do veículo: I - velocidade do veículo; II - distância percorrida pelo veículo; III - tempo de operação do veículo e suas interrupções; IV - data e hora de início da operação; V - identificações do veículo; VI - abertura da caixa que contém o disco diagrama; VII - identificação dos condutores;"

No entanto existem duas outras exigências legais no mesmo documento que representariam empecilho à adoção deste projeto como ferramenta de fiscalização. A primeira delas, "O conjunto deverá obrigatoriamente conter equipamento emissor de fita diagrama para disponibilização das informações registradas”. Esta exigência acrescenta ao sistema a necessidade de um periférico para a impressão da fita diagrama. A simples necessidade deste acrescenta um elevado custo ao projeto, pois além de exigir consumíveis, trata-se de um componente eletro-mecânico de construção compacta que exige processos de mecânica fina em sua construção, sendo por isso mesmo caro e frágil.

A segunda exigência, esta constituindo empecilho legal a adoção deste projeto é o item XI do Art. 7o da resolução No 92, que diz que RIIVT deve "possibilitar leitura fácil, direta e 
sem uso de instrumental próprio no local de fiscalização, nos dados registrados no meio físico". Tal item foi adicionado à resolução a fim não criar empecilhos ao estado no intuito de realizar a fiscalização. Realmente seria um problema caso as autoridades necessitassem portar dispositivos de leitura com diferentes configurações para realizar a leitura de RIIVT's de diferentes fabricantes. Além disso, constituiria mais um custo ao estado adquirir e manter tais dispositivos. Constitui-se uma solução mais fácil obrigar o fabricante do RIIVT a projetar um equipamento com uma interface com o usuário e uma impressora, transferindo-se este custo maior para o proprietário do veículo de carga.

Como discutido no capítulo anterior, a premissa deste projeto é que a fiscalização possa ser realizada sem a intervenção de humanos. Isso implica obrigatoriamente na utilização de dispositivos para a leitura dos parâmetros armazenados no sistema proposto. Entende-se com isso que a adoção deste sistema implicaria na supressão dos artigos restritores da resolução $\mathrm{N}^{\circ}$ 92, não resultando com isso em prejuízo ao parque instalado de RIIVT’s.

Em dezembro de 2009 o INMETRO - Instituto Nacional de Metrologia publicou a portaria $\mathrm{N}^{\circ} 368$ que estabeleceu a obrigatoriedade da calibração anual dos RIIVT. Para isso fixou um calendário que leva em consideração o último algarismo da placa do veículo. A calibração só deve ser executada em postos de verificação credenciados pelo próprio instituto que emite documento atestando a realização do procedimento.

Já o projeto de lei 2260/96 que regulamentaria o tempo máximo de condução para veículos de transporte de carga e de passageiros a partir dos dados pelo RIIVT, depois de anos tramitando no congresso e diversas emendas, foi aprovado naquela casa, mas não sancionado pela Presidência da República. O fato é que o país possui legislação que exige a instalação dos RIIVT's, mas não há legislação que permita que as informações por ele registradas possam ser utilizadas por autoridade policial para autuação de um condutor infrator. 


\subsubsection{O RIIVT Analógico}

Segundo o INMETRO (2009), RIIVT ou cronotacógrafo “instrumento para medição e registro de velocidade, tempo e distância foi criado no século XIX pelo alemão Max Maria Von Weber, com a finalidade de controlar a condução de trens". Com base nos manuais dos fabricantes FIP (2006), ACTIA (2005), SEVA (2001 e 2007), Siemens VDO (2005), observase que depois de constantes evoluções o instrumento de Max Weber hoje é encontrado no Brasil em duas modalidades o analógico e o digital. A Figura 2-2 apresenta a aparência do painel frontal de um tacógrafo analógico.

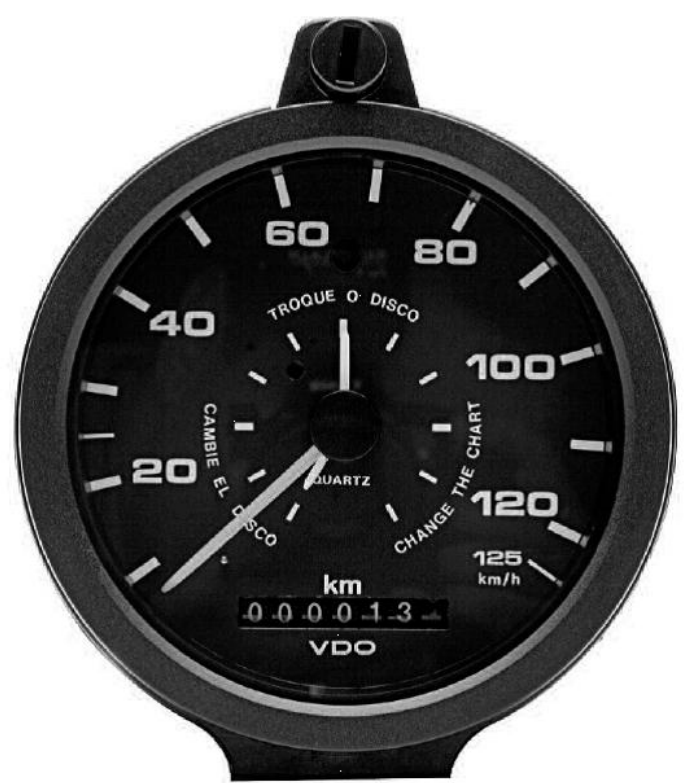

Figura 2-1 - Painel frontal de um tacógrafo analógico (VDO, 2009).

Externamente o RIIVT analógico tem a aparência de um velocímetro, com o acréscimo de outros indicadores relativos às funções que desempenha como, por exemplo, o hodômetro e um relógio.

As informações sobre a distância percorrida, e velocidade do veículo são registradas em um disco de papel reciclado com uma camada de cera e outra de tinta em sua superfície obedecendo a uma impressão gráfica padronizada. A Figura 2-2 apresenta uma imagem dos 
discos de registro com uma descrição detalhada dos campos de registro e de identificação que devem ser manualmente preenchidos a fim de identificar o condutor e o disco.

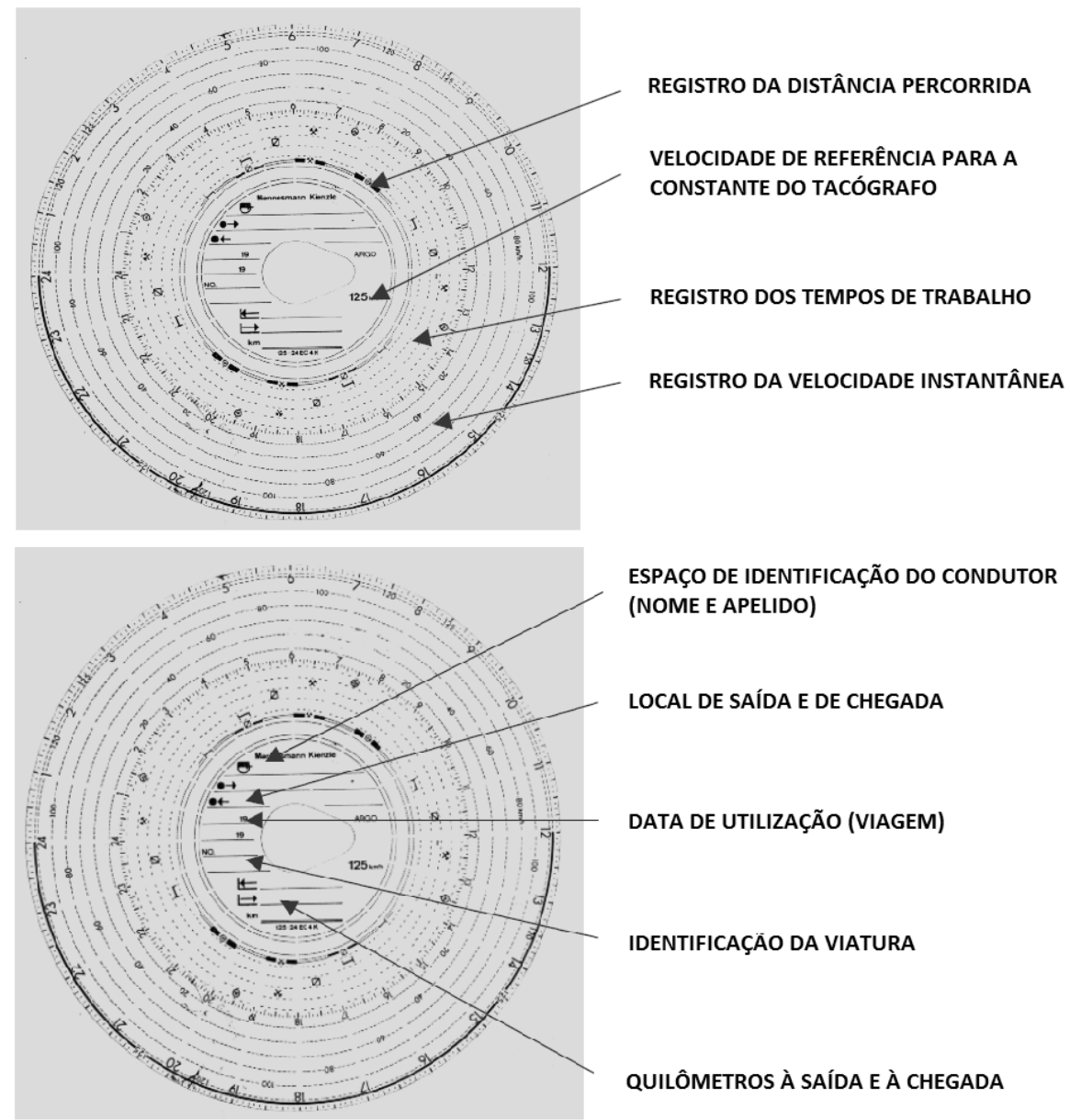

Figura 2-2 - Disco de registro do RIIVT mecânico (IGT, 2009).

Um mecanismo preciso de três ou quatro agulhas com ponta de safira remove a cera depositada na folha deixando assim uma linha com as informações registradas. Este disco de papel gira em velocidade constante de tal forma que uma revolução completa armazene as informações de 24 horas contínuas.

Alguns modelos fazem uso de um arranjo com sete discos sobrepostos, automaticamente cambiáveis, perfazendo assim o registro de uma semana completa.

As medidas de velocidade e deslocamento são provenientes de um cabo mecânico acoplado à saída da caixa de câmbio do veículo que excita o mecanismo das agulhas de registro. Em sua maioria, essa excitação é obtida através de um redutor angular acoplado à 
saída da caixa de câmbio que produz revoluções à medida que o veículo se desloca. Durante o processo de calibração o veículo é submetido a um percurso com deslocamento conhecido, sendo verificado o número de revoluções à saída do redutor acoplado à caixa de cambio. Deste modo obtêm-se uma constante de proporcionalidade para o qual o redutor é ajustado e lacrado pelo período de um ano após o que a calibração deve ser refeita. A Figura 2-3 apresenta a imagem de um redutor angular que vai acoplado a caixa de câmbio .

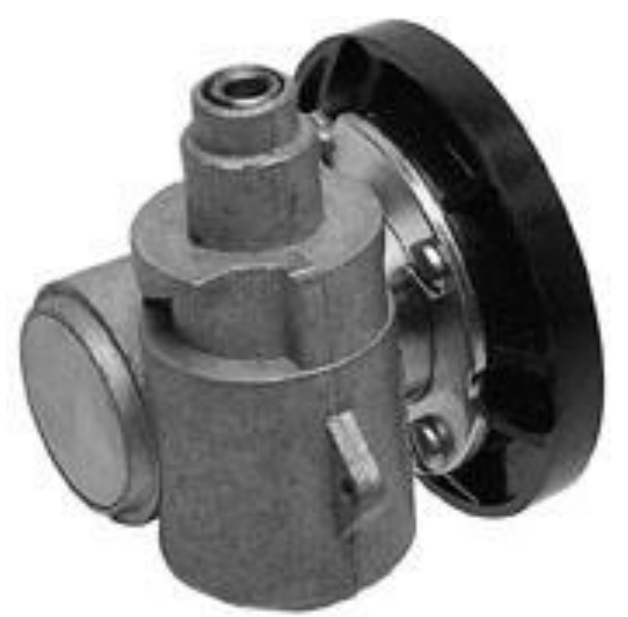

Figura 2-3 - Redutor angular para medida de deslocamento (VDO, 2009).

Segundo o IGT (2009) para o efetivo funcionamento do RIIVT devem ser asseguradas as seguintes condições: Verificações periódicas; Inviolabilidade das selagens e mecanismos de registro; Não abertura do registrador durante o período diário de trabalho, exceto em caso de mudança de veículo ou a pedido das autoridades de trânsito.

A inviolabilidade das selagens é necessária devido à susceptibilidade do RIIVT analógico a fraudes já que pequenas modificações no registrador ou na captação do deslocamento provocam desvios de registro. Outro ponto importante é que os veículos antigos não possuem pré-disposição junto à caixa de câmbio para a instalação do redutor angular o que exige a realização de adaptações no veículo e gera mais custos ao proprietário. 


\subsubsection{O RIIVT Digital}

O RIIVT digital é um sistema computadorizado dedicado à tarefa de mensurar os dados de deslocamento, correlacioná-los com as informações de um relógio eletrônico, com identificação do condutor, e armazená-los em seguida em memórias de estado sólido. Segundo Menig e Coverdill (1999) "Com unidades computadorizadas, informações adicionais podem ser registradas e exibidas, muitas vezes por menos dinheiro do que o requerido para implementar o mecanismo gráfico legal dos tacógrafos analógicos”.

A medida de deslocamento é agora realizada através da contagem de pulsos elétricos que podem ser produzidos de dois modos. Por sensores indutivos que são instalados junto à caixa de câmbio nos veículos que já saem de fábrica com essa predisposição. E por meio de adaptadores que convertem a rotação disponível no cabo mecânico do velocímetro em um trem de pulsos adequados ao RIIVT, nos modelos de veículos sem a prédisposição junto à caixa de câmbio. A Figura 2-4 mostra a esquerda o sensor indutivo acoplável à caixa de câmbio e a direita o conversor adaptável ao cabo do velocímetro.

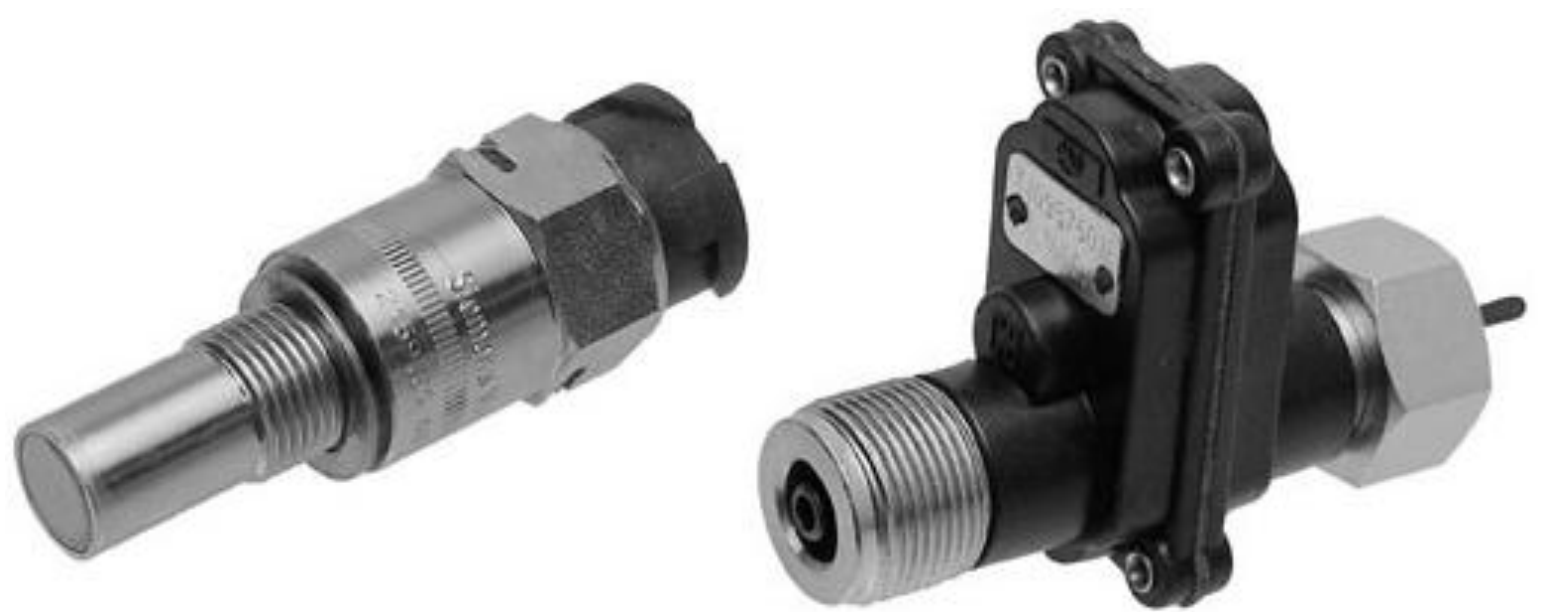

Figura 2-4 - Sensor indutivo e conversor de pulsos para medida de deslocamento (VDO, 2009).

A calibração do RIIVT digital é executada em procedimento semelhante ao do RIIVT mecânico. Depois de determinada a constante de proporcionalidade entre o deslocamento efetivo e o número de pulsos à entrada do RIIVT, a mesma é inserida no instrumento por 
meio de um dispositivo programador. Sendo após protegida por uma senha para impedir a sua alteração por pessoal não autorizado. Uma lógica de proteção impede que se obtenha a senha por tentativa e erro bloqueando o equipamento após certo número de tentativas mal sucedidas.

Tal qual o RIIVT mecânico, o digital deve passar pelo processo de calibração anualmente. Isso é necessário devido à vibração do veículo em funcionamento que pode provocar a descalibração no sistema mecânico, bem como o desgaste ou a mudança da geometria dos pneumáticos pode provocar alterações significativas na medida do deslocamento.

Uma bateria interna mantém o funcionamento do relógio, mesmo na ausência da fonte de alimentação do veículo, por períodos superiores a cinco anos.

As grandes diferenças entre o RIIVT mecânico e o digital são a forma de armazenamento das informações e o modo de identificação do condutor. Como a legislação brasileira não fixa os formatos de armazenamento eletrônico, cada fabricante adota um formato que lhe é conveniente. Em especial quando além de RIIVT o equipamento também acumula outras funções como as de controle do itinerário da frota. Por este motivo e dada à variedade de técnicas de armazenamento, esse assunto será novamente abordado adiante em tópico específico, assim como a identificação do condutor. A Figura 2-5 exibe o painel frontal de um RIIVT digital.

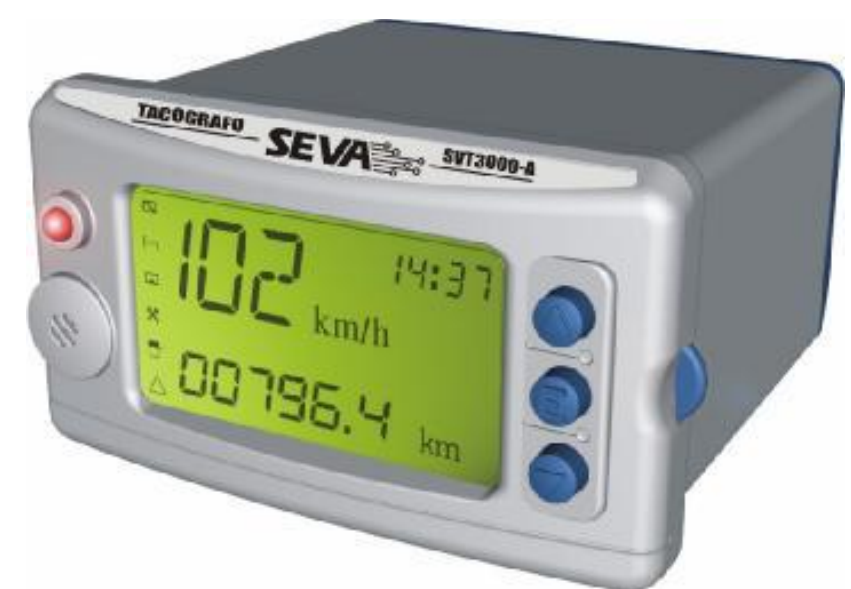

Figura 2-5 - Painel frontal do RIIVT digital SVT-3000A (SEVA, 2001). 


\subsection{O emprego mundial do RIIVT}

Além do Brasil outros países também possuem legislação quanto ao uso dos RIIVT. $\mathrm{Na}$ literatura internacional estes instrumentos são chamados apenas de tacógrafos, inclusive na legislação. Notadamente os países da comunidade européia são os mais adiantados na utilização destes dispositivos. Segundo Granturco (2007) a adoção dos tacógrafos na união européia teve inicio em 1970 com a assinatura de um tratado sob os auspícios da ONU Organização das Nações Unidas. Este tratado, chamado de AETR - European Agreement Concerning the Work of Crews of Vehicles Engaged in International Road Transport, incluía também os países do leste europeu, ex-repúblicas soviéticas e dos Bálcãs.

Através dele ficou determinado que veículos de passageiros com mais de nove acentos, de transporte de carga com mais de 3,5 toneladas estavam obrigados a usar o tacógrafo quando transitando em vias da comunidade européia. O mapa da Figura 2-6 apresenta um panorama mundial da obrigatoriedade do tacógrafo.

Já em 1985 a legislação da comunidade européia foi alterada pelos regulamentos 3820 e 3821, fixando as condições de trabalho dos profissionais de transporte, e ampliando os requisitos técnicos e de calibração dos tacógrafos (IGT, 2009).
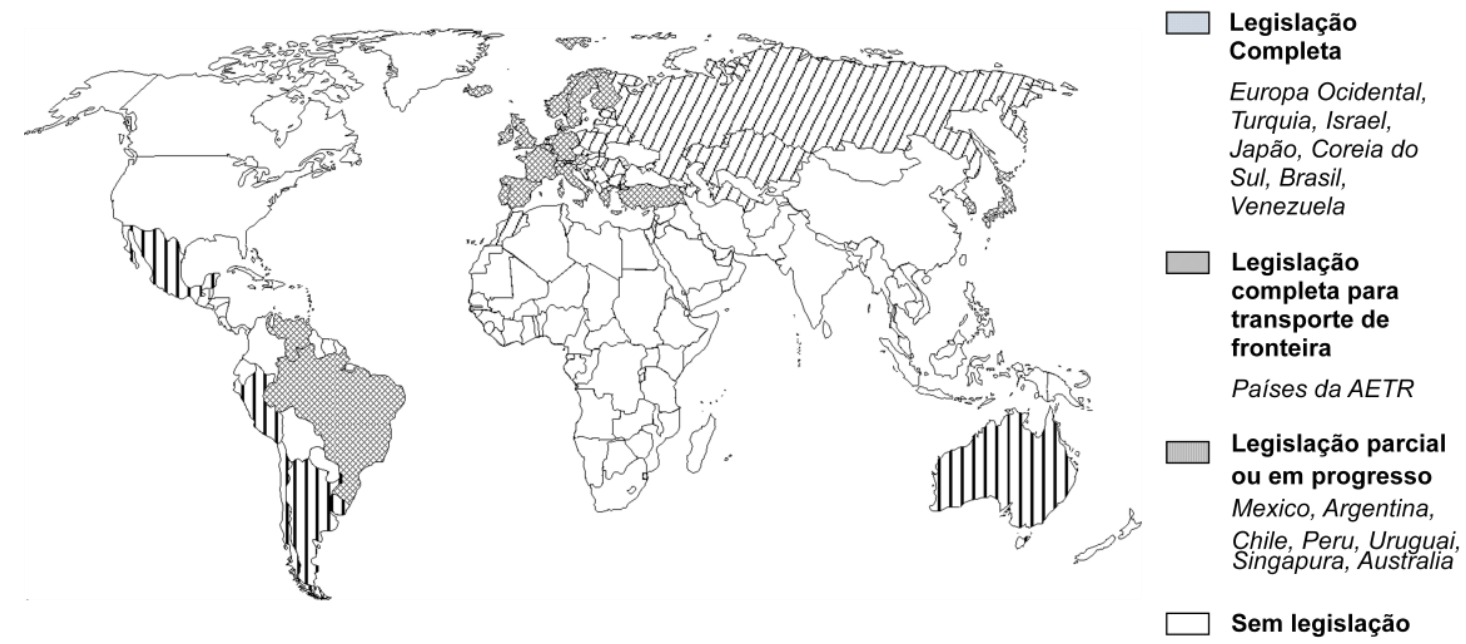

Figura 2-6 - Panorama mundial da exigência de tacógrafo (LEHMANN, 1999). 
Segundo Lehmann (1999) a mudança na legislação européia foi bem sucedida já que aumentou a segurança no trânsito, harmonizou as condições de competição, permitiu a análise de acidentes e o gerênciamento do frete. Lehmann (1999) comprova sua afirmação com o gráfico da Figura 2-7 que apresenta uma evolução da relação quilometragem percorrida / número de acidentes com vítimas na Alemanha entre os anos de 1965 e 1990.

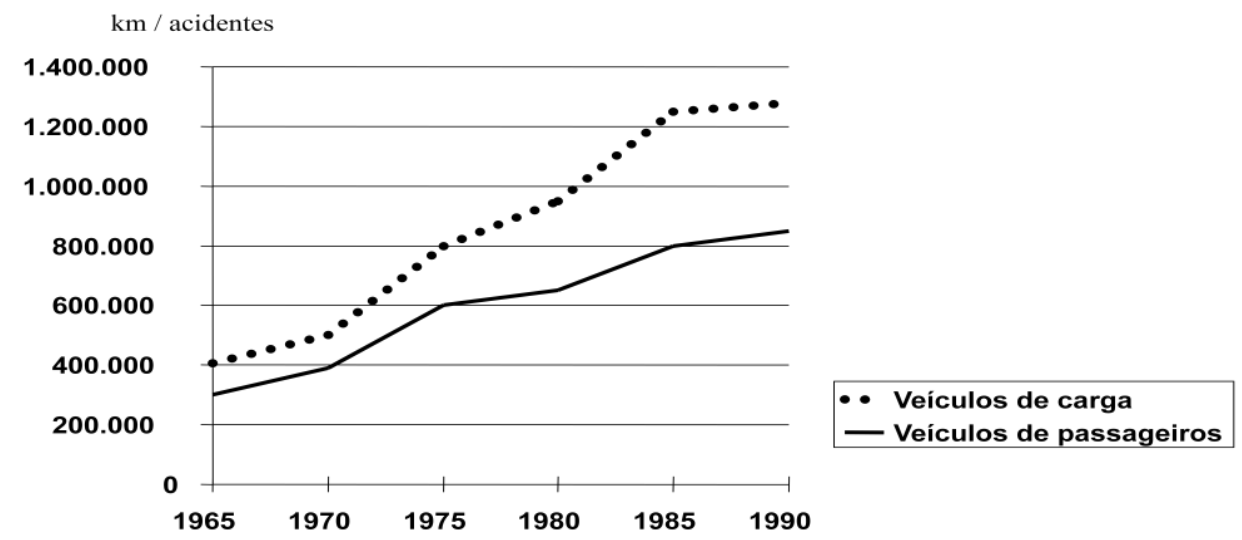

Figura 2-7 - Evolução da quilometragem percorrida / número de acidentes na Alemanha (LEHMANN, 1999).

Rychter (2009) afirma que o tacógrafo analógico não preenchia os requisitos relevantes. "devido à sua construção certas fraudes e falsificações em matéria de trabalho dos motoristas reais eram possíveis." Por esta razão, a união européia voltou a alterar a sua legislação e em 2006 baniu o uso do tacógrafo analógico através da resolução 651, e instituiu a obrigação do tacógrafo digital com grandes modificações em relação ao modelo anterior.

O modelo de implementação do tacógrafo europeu foi bem sucedido e por isso serviu de inspiração para os demais países que estabeleceram o uso do registrador, dentre eles o Brasil. Por este motivo este modelo será detalhadamente discutido adiante.

No restante do mundo a adoção do RIIVT ou tacógrafo encontra-se em diferentes estágios. Os Estados Unidos da América possui uma forte legislação por eles chamada de HOS - Hours of Service ou horas de serviço. Segundo o FMCSA (2009) - Federal Motor Carrier Safety Administration, essa legislação especifica que os condutores de veículos de carga devem registrar em formulários pré-impressos as informações sobre a sua jornada de 
trabalho. Estas informações devem estar sempre disponíveis para a fiscalização das autoridades de trânsito. A legislação também faculta o uso de dispositivos EOBR - Electronic On-Board Recorders for Hours-of-Service Compliance, que funcionam de maneira análoga aos tacógrafos digitais, armazenando as informações da jornada e não permitindo adulterações. Segundo o Truck Safety Coalition (2010), 99\% dos veículos de carga nos Estados Unidos utilizam o registro em papel por aceitarem qualquer tipo de anotações. Por este motivo os registros em papel são chamados pela Truck Safety Coalition de "livros cômicos porque eles são amplamente falsificados por motoristas de caminhão e suas empresas, [...]". A Figura 2-8 exibe o formulário que deve ser diariamente preenchido pelo condutor de veículos de carga nos Estados Unidos.

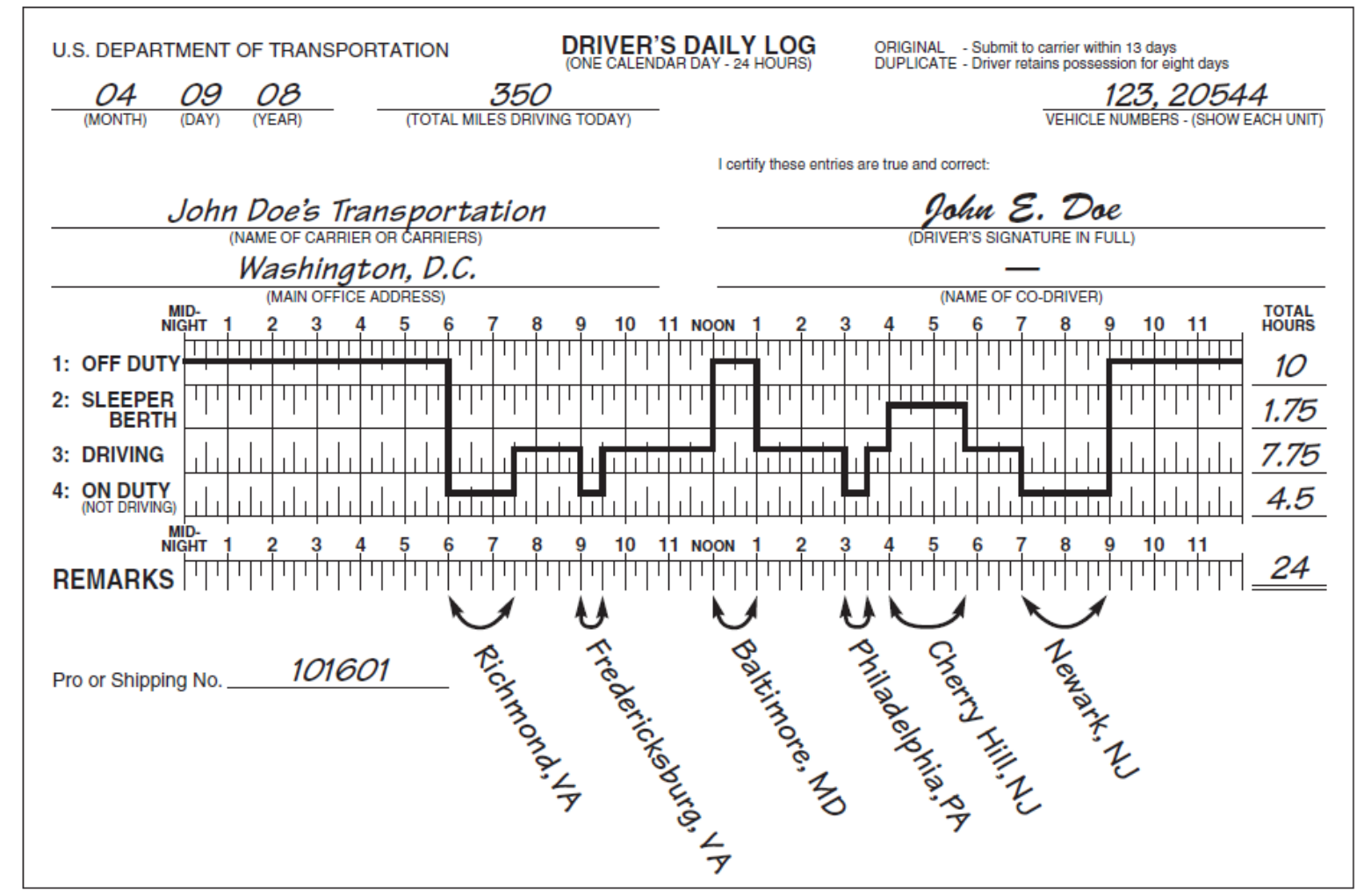

Figura 2-8 - Formulário para registro de horas de condução de veículos de carga nos EUA (FMCSA, 2009).

De maneira análoga a Austrália também possui legislação para o máximo tempo de condução e também não fixa a obrigatoriedade de equipamentos registradores. Segundo NTC - National Transport Comission (2008) na Austrália o condutor deve manter um diário na 
forma de um livro com o registro de suas atividades desenvolvidas e o tempo de descanso. Também é facultativo o uso de registro diário através de dispositivos eletrônicos. Um consórcio firmado entre a Austrália e a Nova Zelândia chamado AUSTROADS encontra-se em fase de estudos dos aspectos financeiros e técnicos da adoção da obrigatoriedade do tacógrafo eletrônico nestes países.

Não foram encontradas referências legais sobre a utilização de registradores em outros países. Acredita-se que isso se deve a não adoção da Internet para divulgação da legislação por estes países. É também relevante observar que o Brasil, hoje, encontra-se na contramão das iniciativas mundiais. Nos outros países estudados implantou-se primeiro a legislação sobre a jornada máxima de condução e depois a obrigatoriedade do registrador. Já no Brasil o registrador é obrigatório, mas os dados armazenados por ele não podem ser utilizados para fiscalização por falta de legislação.

\subsection{O tacógrafo digital da comunidade européia}

A implantação do tacógrafo digital em substituição ao analógico na comunidade européia não se resumiu à mudança do equipamento em si. Ela foi mais além constituindo grupos de trabalho para a especificação de normas técnicas dos equipamentos, definição da infraestrutura governamental de tecnologia da informação, privacidade dos dados, e a estrutura de credenciamento de fornecedores, equipamentos, instaladores e cadeia metrológica.

\subsubsection{A unidade do veículo - VU}

O RIIVT ou tacógrafo é constituído pela unidade de veículo e um sensor de movimentos. A unidade do veículo inclui uma unidade de processamento central, uma memória de dados, um relógio de tempo real com bateria independente, duas interfaces para cartões inteligentes, uma impressora para relatórios, um visor, um alerta visual, um conector 
de calibração e download e os controles para a introdução de dados por parte do condutor. Alguns modelos possuem entrada para o barramento CAN - Control Area Network para o registro de outros parâmetros do veículo disponíveis através do mesmo. A Figura 2-9 exibe o diagrama de blocos funcionais da unidade de veículo européia (GRANTURCO, 2007). A unidade do veículo aceita os sensores digitais tradicionais de deslocamento semelhantes aos adotados no Brasil, mas também prevê a utilização de sensores inteligentes que se comunicam com a unidade do veículo por meio de mensagens criptografadas o que libera a instalação do sensor da necessidade de lacração.

Os dados sobre condução são armazenados em memórias de estado sólido, com acesso protegido por meio de um sistema criptográfico com base em cartões inteligentes. A legislação européia prevê quatro tipos de cartões: cartão do condutor; cartão da empresa; cartão do centro de aferição e cartão de fiscalização.

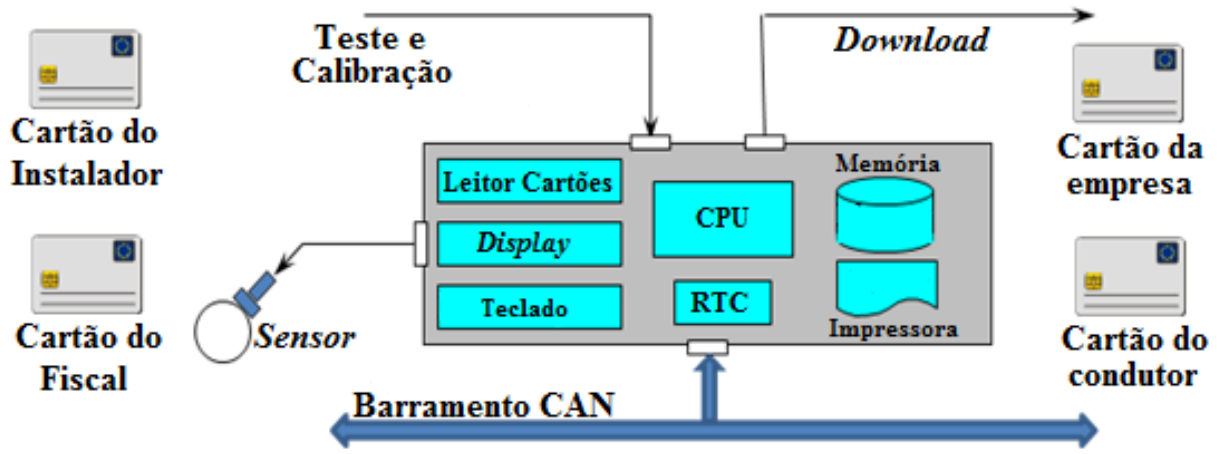

Figura 2-9 - Diagrama de blocos da unidade de veículo européia (GRANTURCO, 2007).

O processo de ensaio e calibração é executado de maneira similar ao modelo Brasileiro, exceto pela necessidade do cartão de aferição sem o qual não é possível alterar a constante de proporcionalidade do registrador.

\subsubsection{Os cartões inteligentes}

Segundo Wolfgang R. e Wolfgang E. (2002) os cartões inteligentes ou Smart Cards são “cartões plásticos de identificação dotados de circuitos eletrônicos em seu interior”. Estes 
circuitos incorporados no cartão contêm os componentes de transmissão, armazenamento e processamento de dados. Mensagens podem ser transmitidas através de contatos na superfície do cartão ou por meios de campos eletromagnéticos, sem nenhum contato. Chip's com mais de 256 kbytes de memória estão disponíveis atualmente, e este número se multiplica a cada nova geração de chips. Wolfgang R. e Wolfgang E. (2002) afirmam ainda que:

“[...] uma das mais importantes vantagens dos cartões inteligentes é que os dados armazenados podem ser protegidos contra o acesso não autorizado e manipulações. Como seus dados só podem ser acessados através de uma interface serial que é controlada por um sistema operacional e uma lógica de segurança, dados confidenciais podem ser gravados no cartão de uma forma que os impedem de serem lidos de fora do cartão. Tais dados confidenciais podem ser manipulados apenas internamente pela unidade de processamento do chip".

A Figura 2-10 exibe o diagrama dos blocos internos de um cartão inteligente e a aparência e o aspecto externo do mesmo.

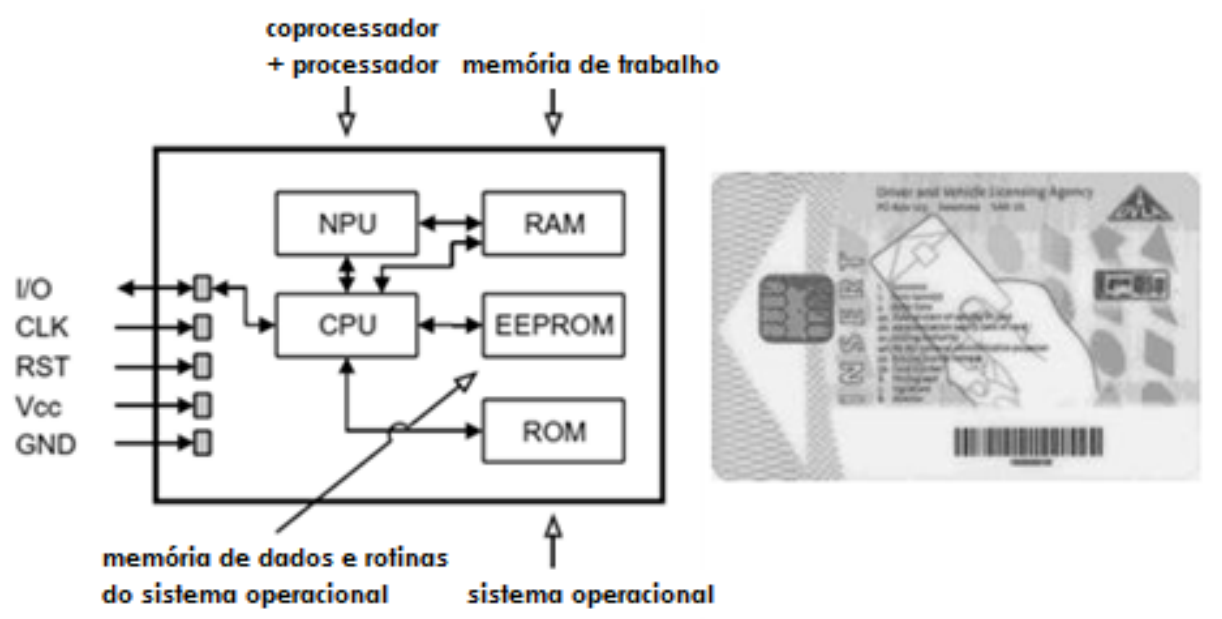

Figura 2-10 - Diagrama de blocos de um cartão inteligente e sua aparência (WOLFGANG R. E WOLFGANG E., 2002).

De uma maneira simplificada é possível afirmar que estes cartões podem armazenar informações impossíveis de serem copiadas por outra pessoa que não o programador do cartão.

Aliando-se os mecanismos de segurança de hardware e software com co-processador dedicado a computar os algoritmos de criptografia permite que os cartões inteligentes possam 
ser utilizados para programar módulos de segurança portáteis na forma de cartões. A produção destes cartões está normalizada através da ISO-7816 que padroniza as características lógicas do mesmo. O modelo de implementação do tacógrafo da comunidade européia utiliza-se destes cartões inteligentes como meio de autorização e módulo de criptografia. Os cartões de condutor, aferição, fiscalização ou da empresa armazenam em seu interior diferentes chaves criptográficas que dão diferentes níveis de acesso aos dados e parâmetros do tacógrafo.

\subsubsection{A estrutura de criptografia}

Criptografia é o estudo de métodos utilizados para encriptar e decriptar dados. Os quatro objetivos da criptografia são: manter confidencialidade dos dados; garantir integridade dos dados impedindo-os de serem alterados; a autenticação para confirmar que determinados dados são de propriedade de certo usuário; e a irretratabilidade, processo pelo qual um usuário não pode negar a propriedade dos dados. Estes objetivos são independentes entre si, e colocam diferentes exigências sobre o módulo de criptografia.

Para garantir estas exigências a comunidade européia escolheu o modelo de criptografia por chave pública $\mathrm{RSA}^{3}$. Neste modelo os dados a serem protegidos devem ser encriptados utilizando-se a chave pública do destinatário, que é conhecida por todos os envolvidos no processo, e somente será decriptável com a chave privada do destinatário que é restrita. Esse método também garante autenticação e irretratabilidade, pois a chave pública do emissor dos dados encriptados passa a fazer parte dos dados, garantindo assim a sua procedência.

Desta forma o ERCA (2010) - European Root Certification Authority gera um par de chaves RSA e as usa para certificar as chaves publicas geradas pelos NCA's - National

\footnotetext{
${ }^{3}$ RSA = Rivest, Shamir e Adleman, inventores da técnica de criptografia RSA.
} 
Certification Authoritys. Os NCA's certificam as chaves RSA inseridas na unidade veicular ou tacógrafo e nos cartões inteligentes pelos CP's - Component Pesonalizers. As especificações técnicas da unidade veicular não permitem a alteração da chave RSA da ERCA, mas a chave dos NCA's é trocada periodicamente. O formato do certificado de chave pública utilizado pelo modelo europeu é proprietário e incompatível com a especificação X.509 mundialmente adotada.

O ERCA gera, divide e distribui uma única chave criptográfica necessária para proteger os dados de deslocamento do veículo, de acordo com os mecanismos definidos na norma ISO/IEC 16844-3. A chave mestra Km - Key master é utilizada por uma NCA para criptografar dados de identificação para serem inseridos nos sensores de movimento. A chave mestra é dividida em duas partes KmVU - Key master Veicular Unit e KmWC - Key master Workshop Card, que são inseridas nas unidades veiculares e nos cartões de aferição por um $\mathrm{CP}^{4}$.

Para assegurar a confidencialidade das chaves do sensor de movimento durante o transporte da ERCA para uma NCA ou CP, o ERCA criptografa a chave do sensor de movimento usando uma chave RSA pública, produzindo uma mensagem de distribuição de chaves KDM. Essa chave RSA pública utilizada na produção do KDM - Key Distribution Message são geradas pelo NCA ou CP e enviadas para o ERCA em uma solicitação de distribuição de chaves KDR - Key Distribution Request.

Esse complexo procedimento garante a segurança e a confidencialidade do sistema tacógrafo europeu. Mas para que esse procedimento complexo de manipulação de troca de chaves seja realizável, foi necessário investir em uma infra-estrutura de TI - Tecnologia da

\footnotetext{
${ }^{4} \mathrm{CP}=$ Component Pesonalizers.
} 
Informação. Assim foi criada a TachoNET como uma rede telemática para facilitar a troca de dados entre as administrações dos países responsáveis pela emissão dos cartões de tacógrafos.

\subsection{Alternativas para a medida de deslocamento e direção de veículos}

Skog e Hadel (2009) explicam que atualmente existem quatro diferentes técnicas disponíveis para a medida de deslocamento e direção de veículos: hodômetros, encoders de velocidade, bússola eletrônica e plataformas inerciais.

Hodômetro é o instrumento que provê informações sobre a distância curvilínea percorrida por um veículo medindo-se o número de rotações das rodas do veículo. Isso é feito por um encoder que entrega um número inteiro de pulsos para cada revolução das rodas. $\mathrm{O}$ número de pulsos durante um determinado intervalo de tempo é mapeado para uma estimativa da distância percorrida durante o intervalo de tempo, multiplicando-se este valor por um fator de escala que depende do raio da roda. Esta é a técnica utilizada pelo modelo de tacógrafo da Comunidade Européia, com o diferencial de que a rotação é tomada na saída da caixa de câmbio e não nas rodas.

Para a determinação da direção do veículo, Carlson, Gerdes e Powell (2002) afirmam que é possível medir o deslocamento angular do volante do veículo, obtendo-se assim uma medida do ângulo de esterçamento das rodas dianteiras em relação ao eixo de guinada deste. Correlacionar essa informação com a velocidade das rodas dianteiras, permite calcular uma estimativa da direção do veículo.

Outra possibilidade segundo Skog e Hadel (2009) é medir e analisar a diferença de velocidade entre as rodas do veículo, extraindo-se daí a informação do ângulo de esterçamento. O ponto positivo desta técnica é que ela permite o uso dos sensores do sistema ABS. Mas o erro relativo à baixa resolução dos sensores ABS pode afetar a confiabilidade da estimação de posição. 
Essas técnicas para estimar a distância percorrida, velocidade, e posição do veículo são todos baseados no pressuposto de que as rotações das rodas podem ser traduzidas em deslocamentos lineares relativas ao solo. No entanto, existem várias fontes de imprecisão na tradução das leituras dos encoders de roda, entre eles: escorregamento das rodas, superfícies irregulares, derrapagens, mudanças na geometria dos pneus em função da temperatura, rodas de diâmetros diferentes no mesmo veículo, limitações da resolução dos encoders de roda e baixa taxa de amostragem dos sinais.

As primeiras três fontes de erro citadas são dependentes do terreno e podem ocorrer de uma maneira não sistemática, o que torna mais difícil a predição e limitação de seus efeitos negativos na acuracidade da estimação de parâmetros. As demais fontes de erro ocorrem de maneira sistemática e seu impacto é mais facilmente previsível. Estes erros podem ser reduzidos aplicando-se parâmetros de correção na utilização dos sensores.

Já uma bussola eletrônica é um componente eletrônico que fornece medidas de direção relativas ao pólo norte magnético da Terra. Contudo, existe uma diferença importante entre a localização dos pólos norte magnético e o norte geográfico. Para realizar esta correção entre os diferentes pólos, é necessário conhecer a localização da bússola, pois a decimação magnética, que é o ângulo entre o norte magnético e o norte geográfico, é dependente do local.

Peters (1986), explica que as bussolas são construídas sobre três magnetômetros magnetoresistivos, em conjunto com sensores para a medida de arfagem e rolamento. As medidas de arfagem e rolamento são necessárias para determinar a atitude do sistema de coordenadas dos sensores magnéticos com relação ao plano horizontal, de maneira que a componente horizontal do campo magnético da Terra pode ser calculada através destas medidas. 
Para um veículo se movendo em um ambiente plano, experimentando apenas pequenos ângulos de guinada e arfagem, uma bússola construída a partir de apenas dois magnetômetros com boa sensibilidade e eixos perpendiculares próximos ao plano horizontal pode ser tecnicamente eficiente e barata.

Contudo, linhas de transmissão de energia e grandes estruturas de metal como pontes e edifícios ao longo da trajetória do veículo podem causar variações no campo magnético local, resultando em grandes e imprevisíveis erros na estimativa da direção da bussola. Portanto, a utilidade das bússolas magnéticas em sistemas de navegação automotivas é questionável (SKOG E HADEL, 2009).

O acelerômetro por sua vez provê informação sobre a aceleração de um objeto ao qual está ligado. Mais especificamente, um acelerômetro produz uma saída proporcional à força específica exercida sobre o sensor. Informações sobre a orientação do objeto e a sua rotação podem ser obtidas com o uso de um giroscópio, que mede a velocidade angular de um objeto relativo à plataforma inercial de referência. Portanto, ao equipar o veículo com sensores inerciais, ou seja, acelerômetros e giroscópios, informações sobre a aceleração e rotação do veículo podem ser obtidas e mapeadas em estimativas de atitude do veículo, velocidade e posição.

Skog e Hadel (2009) afirmam também que progresso nos sistemas de sensores $\mathrm{MEMS}^{5}$, tornou possível a construção de sensores inerciais reunindo o baixo custo, tamanho reduzido e baixo consumo necessários para o emprego em eletrônica veicular. No entanto, o preço a ser pago pelos sensores disponíveis é o baixo desempenho.

Os sistemas inerciais de qualquer espécie possuem características não absolutas. Em outras palavras, não fornecem a posição absoluta de um móvel mas sim o deslocamento a

\footnotetext{
${ }^{5}$ MEMS $=$ Microelectromechanical systems
} 
partir de um ponto inicial conhecido. Esse ponto fragiliza esta tecnologia em especial por requerer um processo de referenciamento a cada vez que se recuperar de uma falha.

Já o sistema GPS possui as características de posicionamento absoluto por possuir um sistema de referenciamento automático constantemente disponível. Assim, é possível saber não somente o deslocamento do veículo em um intervalo do tempo, mas também por quais vias ele teria percorrido. Isso por si só traz novas possibilidades ao RIIVT. O sistema GPS também possui os seus inconvenientes, todos eles ligados as condições de recepção dos sinais advindos dos satélites. Já a adoção de um sistema de recepção GPS aliado a um sistema inercial baseado em acelerômetros e giroscópios tornaria o sistema totalmente tolerante a falhas.

\title{
2.5 Global Positioning System - GPS
}

Silveira (2004), assim explica o sistema GPS:

\begin{abstract}
"O sistema de posicionamento global por satélites, NAVSTAR-GPS (Navigation System Using Time and Ranging e Global Positioning System), foi projetado pelo departamento de defesa dos EUA (DOD - Department of Defense) no início dos anos 60 e dado como operacional em 08 de Dezembro de 1993, com o objetivo de fornecer uma cobertura global, vinte e quatro horas e informando a posição de tropas militares e posteriormente à comunidade civil."
\end{abstract}

Segundo Dana (2000) Este sistema é constituído por três segmentos: espacial; de controle; do usuário. O segmento espacial é composto por uma constelação de vinte e quatro satélites, que orbitam a Terra em uma altitude aproximada de $20.200 \mathrm{~km}$ acima do nível do mar. Estes satélites percorrem seis órbitas inclinadas em relação ao Equador, estáveis e assíncronas, com quatro satélites em cada uma. Estes perfazem uma órbita completa a cada 12 horas sendo que cada satélite possui $28^{\circ}$ de cobertura da superfície Terrestre. Com isso assegura-se que todo e qualquer ponto, em qualquer instante, esteja sob a cobertura de pelo menos quatro satélites. A Figura 2-11 apresenta a representação das órbitas dos satélites. 


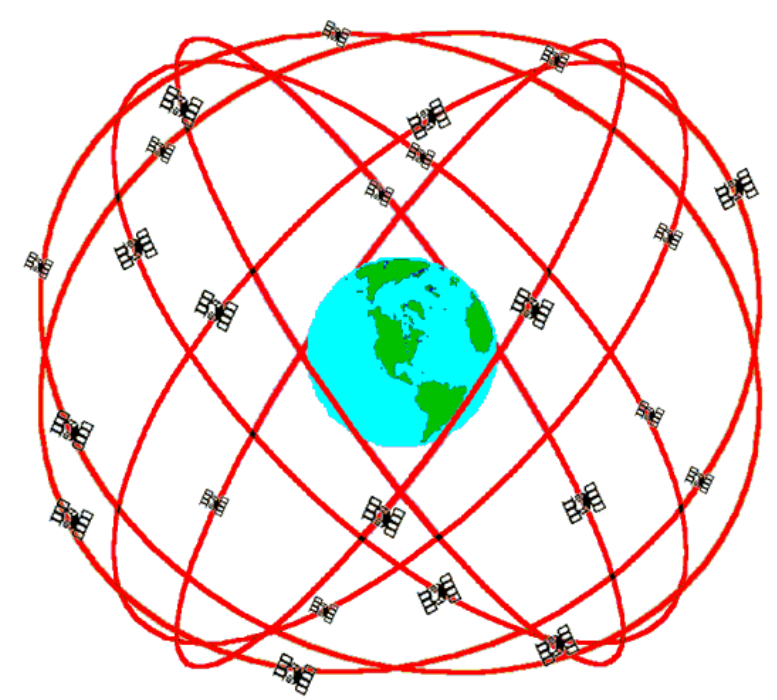

Figura 2-11 - Órbitas dos satélites do sistema GPS (DANA, 2000).

A base de tempo nos satélites é mantida por um complexo arranjo com dois relógios de césio e dois de rubídio, Silveira (2004), oferecendo assim estabilidade e redundância. Cada satélite é então programado para emitir em direção a Terra dois sinais de rádio distintos, chamados de L1 e L2, operando nas freqüências de 1575,42 MHz e 1227,60 MHz respectivamente.

O sinal L1 é modulado pelo código C/A - Clear Access, e o sinal L2 modulado pelo código P - Precise Code. Adicionalmente os sinais L1 e L2 transmitem também mensagens sobre a efeméride e sobre as condições técnicas do equipamento, mas estas informações não são relevantes para a navegação. A Figura 2-12 apresenta o arranjo de modulação dos sinais L1 e L2.

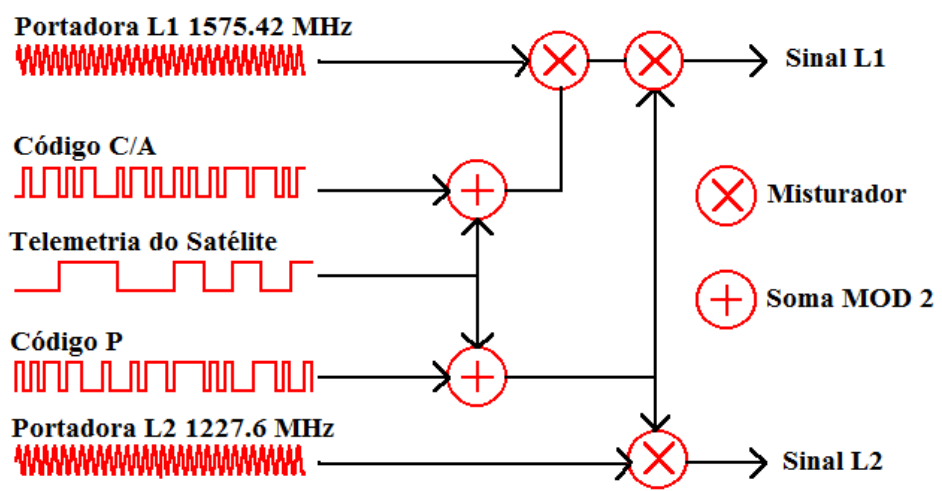

Figura 2-12 - Arranjo de modulação dos sinais GPS (DANA, 2000). 
O segmento de controle do sistema GPS é constituído por um grupo de cinco estações terrestres que registram os sinais dos satélites, efetuam medidas meteorológicas e enviam os dados a uma estação principal, que calcula as efemérides (informações sobre as órbitas) dos satélites, bem como os coeficientes de correção dos relógios e os transmite para os satélites.

O terceiro segmento do sistema, o do usuário, consiste da unidade receptora, que recebe os sinais provenientes dos satélites e determina a diferença entre o instante em que foi emitida e recebida. Isso é possível pela análise dos códigos C/A e P transmitidos pelo satélite, que transportam a informação do instante da transmissão e do relógio interno do receptor que foi sincronizado com o do satélite através do sinal P. Conhecendo-se então o tempo de propagação da mensagem, que é da ordem de décimos de segundo, o receptor calcula a distância entre o receptor e o satélite, multiplicando-se o intervalo de tempo pela velocidade de propagação do sinal de rádio, que é aproximadamente igual à velocidade da luz.

Considerando-se a distância entre o satélite é o receptor como sendo o raio de uma circunferência imaginária. E calculando-se a interseção de pelo menos outras três circunferências que se formam entre o receptor e outros três diferentes satélites, têm-se a posição exata do receptor na superfície da Terra em coordenadas geográficas, latitude, longitude e elevação. A Figura 2-13 apresenta uma representação do sistema de determinação da posição por interseção de circunferências no sistema GPS.

Alves (2006) chama a atenção de que a base de tempo é o fator essencial na operação do GPS. Um erro de um micro segundo no cálculo da diferença de tempo da transmissão pelo satélite até a sua recepção resulta num erro de aproximadamente 300 metros. Unidades receptoras GPS de alta precisão são capazes de determinar sua posição com erro máximo de até um metro. 


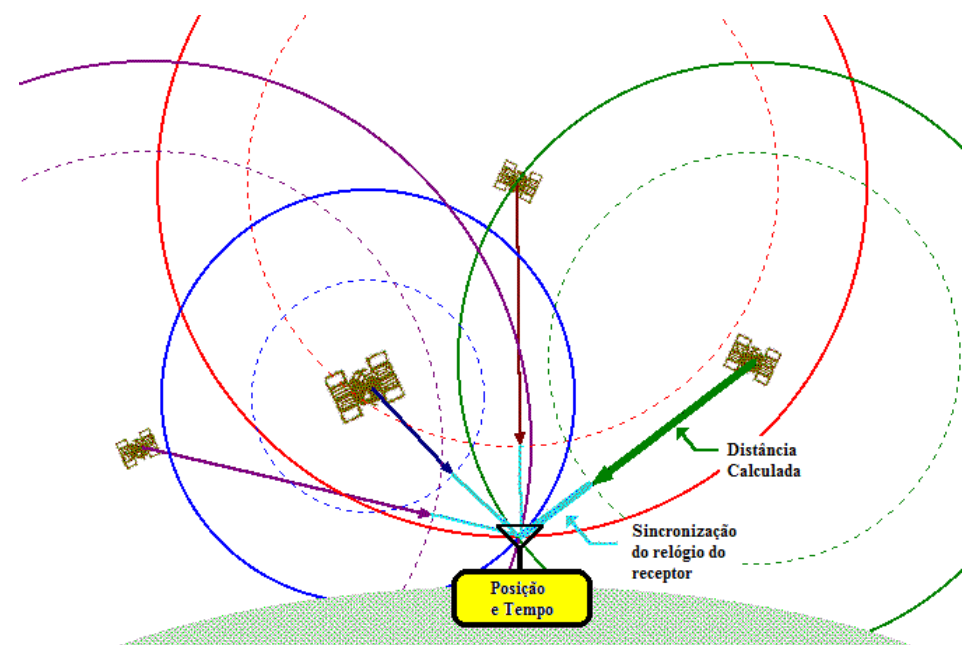

Figura 2-13 - Interseção de circunferências no sistema GPS (DANA, 2000).

\subsubsection{Os erros de posicionamento no sistema GPS}

Segundo Segantine (1995):

“...as fontes de erros estão associadas ao posicionamento de um ponto. Os erros significativos, que impedem a precisão no posicionamento com GPS, devem-se, principalmente, às imprecisões da órbita dos satélites e às influências da ionosfera e da troposfera."

Desde o lançamento do sistema GPS novas técnicas de processamento foram desenvolvidas, em especial visando cancelar os erros devidos às influências atmosféricas sofridas na ionosfera e na troposfera. Contudo, uma fonte de erro que ainda influencia fortemente a precisão do sistema é o DOP - Diluition of Precision ou Diluição da Precisão.

Chama-se de DOP o coeficiente que indica, em uma escala padronizada, se a geometria espacial dos satélites naquele instante pode ser considerada boa. Este coeficiente é inversamente proporcional ao volume do corpo sólido gerado pelos satélites e o ponto a determinar. Dessa forma, quanto maior o volume, menor o DOP. Considera-se então que a melhor disposição espacial é um satélite no zênite e os outros com ângulos horizontais igualmente espaçados, o que equivale a um DOP baixo, Figura 2-14 (a).

De maneira análoga inversa quanto maior o DOP pior é a disposição espacial dos satélites naquele instante, Figura 2-14 (b). A única solução possível para manter os satélites 
em posição sempre favorável é aumentar o seu número em cada uma das órbitas. Porém esta é uma situação de custo muito elevado e que independe da vontade dos usuários.

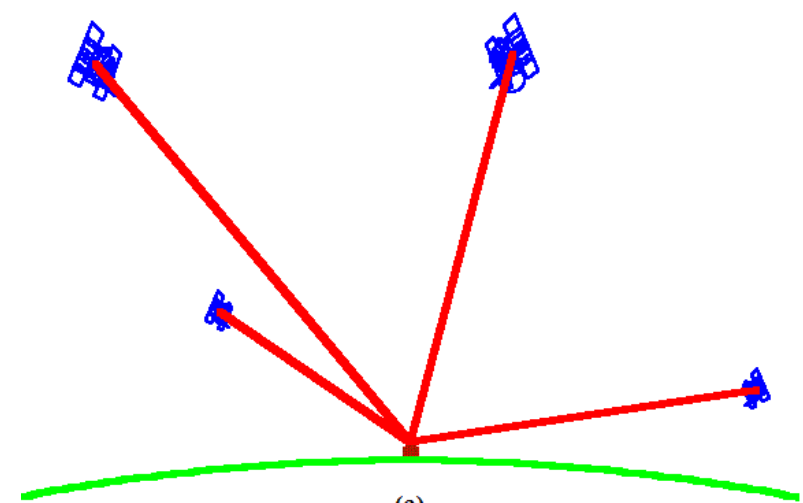

(a)

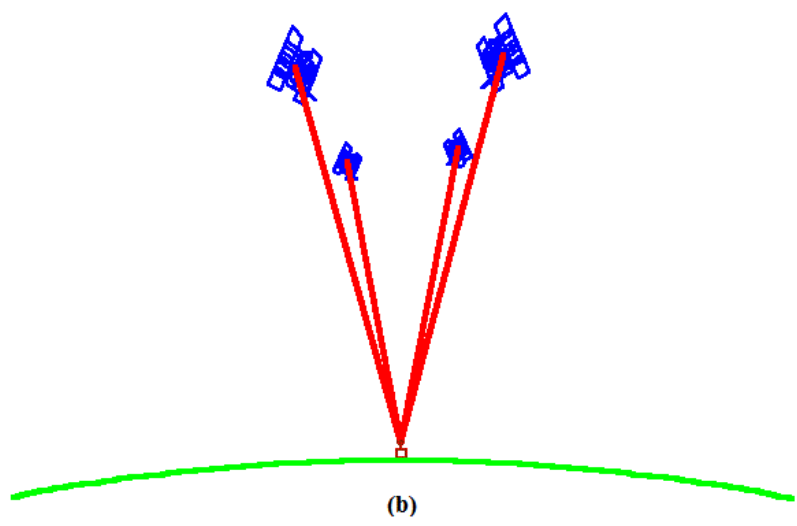

(b)

Figura 2-14 - (a) Posicionamento ideal DOP baixo, (b) Posicionamento ruim DOP alto (DANA, 2000).

O coeficiente DOP então serve como um indicativo da precisão do sistema naquele instante e pode permitir que o sistema trate essa situação de maneira conveniente. Cabe ainda lembrar que o sistema GPS é extremamente dinâmico por concepção de modo que as condições em um instante podem não ser as mesmas no instante seguinte.

Outra fonte de erros, porém agora erros propositais, é o subsistema de disponibilidade seletiva. Este sistema permite ao governo americano desligar ou mesmo introduzir erros no sistema GPS para que inimigos militares não façam uso do sistema GPS. Durante o período de redação deste trabalho o sistema de disponibilidade seletiva estava desativado por ordem presidencial daquele país. Contudo, por se tratar de uma decisão política, pode ser revogada a qualquer momento.

\subsection{Iniciativas pertinentes}

Embora não façam referência direta à cronotacógrafos ou RIIVT’s, alguns dos trabalhos pesquisados apresentaram informações relevantes ao desenvolvimento da proposta apresentada e por este motivo merecem citação detalhada. 
O projeto VERONICA desenvolvido pela diretoria geral de energia e transporte da Comunidade Européia, tem o objetivo de levantar requisitos para a adoção dos $\operatorname{EDR}^{\prime}{ }^{6}$ nos veículos em circulação pela Europa. No relatório final do projeto Schimidt-Cotta et al. (2006), explica-se que o modelo de tacógrafo adotado na Europa em 2006, em substituição à versão mecânica, terminou dificultando o trabalho de descoberta de evidencias para a explicação dos acidentes. Principalmente em função de sua baixa resolução para registro de velocidade, por não possuir gatilhos para detecção de eventos, e por não registrar a ocorrência de acelerações laterais. Além de identificar os pontos negativos do projeto do tacógrafo da Comunidade Européia, os pesquisadores do VERONICA elencam uma série de recomendações que devem ser atendidas pelo próximo grupo de trabalho para o projeto EDR. Dentre todas as recomendações três em especial são as mais relevantes. O EDR deverá ser montado livre de vibrações, ou seja, fixo à estrutura do veículo, formando ângulos retos com os eixos do mesmo. O EDR deverá possuir também um código chamado $\mathrm{URN}^{7}$, que deverá identificar inequivocamente o equipamento e o veículo, impossibilitando que o equipamento de um veículo seja instalado em outro.

Quanto aos requisitos técnicos, os pesquisadores do projeto Veronica recomendam que os EDR's devem realizar as aquisições de dados de aceleração a uma taxa de 100 a $2000 \mathrm{~Hz}$, e registrá-las a uma taxa de 100 a $500 \mathrm{~Hz}$.

Como justificativa para a implantação do EDR na Comunidade Européia, seus idealizadores citam a iniciativa Pay as you drive - Pague conforme você dirige, que é uma forma de contrato firmado entre o condutor do veículo e sua empresa de seguros. Cabe ao motorista decidir como, quando e onde ele dirige, sabendo que o valor do prêmio de seu seguro será influenciado por isso. Desta forma os motoristas que conduzem os seus veículos

\footnotetext{
${ }^{6} \mathrm{EDR}=$ Event Data Recorders.

${ }^{7} \mathrm{URN}=$ Unique Reference Number.
} 
de forma segura deixarão de financiar os custos decorrentes dos acidentes dos maus motoristas. Além disso, o pay as you drive pode ser entendido como uma oportunidade de negócio baseado no EDR, o que pode ajudar na implantação do mesmo.

Em outro trabalho, Dantu e Langle (2009), propõem a utilização dos acelerômetros presentes no Google Phone para classificar condutores quanto a sua habilidade para direção segura. Ele considerou distância de frenagem, aceleração e desaceleração como parâmetros para classificar os tipos de condutores, e o deslocamento no eixo perpendicular à trajetória para classificar mudanças de pista seguras. Contudo, a iniciativa não obteve o êxito esperado, pois os sensores do Google Phone não possuem a resolução adequada à aplicação.

\subsection{A aplicação eletrônica da lei - e-enforcement}

Bruijn e Berlo (2006) definem que o e-enforcement consiste no uso de ferramentas eletrônicas para aplicação automática da lei, e divide os sistemas que as compõem entre os de primeira e segunda geração.

Os sistemas de primeira geração possuem duas características distintivas, a primeira delas é que a execução da lei é baseada em somente uma variável que é verificada pelo aparato eletrônico: o condutor cruzou o sinal fechado? O condutor excedeu o limite de velocidade? A segunda característica importante dos sistemas de primeira geração é que a verificação do cumprimento da lei acontece em um local particular onde o equipamento está instalado e em apenas um instante de tempo.

Atualmente os sistemas de e-enforcement são largamente adotados, é possível encontrar estes sistemas em rodovias e ruas e avenidas por todo o país. Bruijn e Berlo (2006) relatam ainda que existem registros da utilização destes sistemas por 75 países em todo o planeta. 
Já os sistemas de segunda geração são capazes de realizar medidas em variáveis multidimensionais e verificar o cumprimento da lei de uma maneira estrutural. Exemplos dos sistemas de segunda geração são: a pesagem em movimento, que é multidimensional, pois é diretamente afetada pela velocidade do veículo, e o SINIAV que se encontra em implantação no Brasil e permitirá aferir a velocidade média do veículo ao longo do trajeto.

Baseado no exposto, conclui-se que o projeto apresentado neste trabalho enquadra-se na categoria de e-enforcement de segunda geração, pois permite que a fiscalização seja realizada durante todo o percurso do veículo, além de coletar diversas informações sobre a condução do mesmo.

\subsection{Os certificados digitais}

Segundo Ribeiro (2010), “certificação digital é um conjunto de processos e técnicas que dão maior segurança às comunicações e às transações eletrônicas." Sua função é impedir que dados eletrônicos sejam interceptados ou adulterados nos processos de comunicação e armazenamento. Seus dois principais elementos são o certificado e a assinatura digitais, que fazem uso das técnicas de criptografia.

O certificado digital é um documento em meio eletrônico que contém informações que identificam inequivocamente uma pessoa, uma máquina ou uma instituição fazendo uso de um software como intermediário que reconheça essa informação. Ele pode ser emitido a pessoas físicas, jurídicas, equipamentos e aplicações. A emissão é feita por uma entidade considerada confiável, chamada Autoridade Certificadora, CA nos países de língua inglesa. É ela quem fornece ao usuário um par de chaves criptográficas. São essas chaves, emitidas e geradas pelo próprio usuário no momento da aquisição do certificado, que podem criptografar um documento eletrônico. Um certificado pode ser usado em conjunto com uma assinatura 
digital. Neste caso, a assinatura digital fica de tal modo vinculada ao documento eletrônico que qualquer alteração o torna inválido.

Traçando-se uma analogia com documentos do mundo real, o certificado digital seria o similar eletrônico do RG, enquanto a assinatura digital, o equivalente ao carimbo acompanhado de selo que os cartórios brasileiros colocam para reconhecer firma em documentos. Juntos, esses dois elementos, aliados à criptografia, garantem a autenticidade, a integridade, o não repúdio à transação e a confidencialidade da informação. Ou seja, as partes são mesmo quem dizem ser, e a transação é legítima, autêntica, segura e não sofreu alterações ao longo do processo.

O uso da criptografia assimétrica garante a confiabilidade e a autenticidade da comunicação. O método para assegurar sua integridade e origem consiste em combinar o uso de chaves públicas com uma assinatura digital (SILVA, 2010). Assim como a criptografia assimétrica, a assinatura digital é uma seqüência de bits resultante de uma operação matemática conhecida como função hashing. Essa função analisa todo o documento ou arquivo e, com base no algoritmo matemático, gera um valor de tamanho fixo para ele. Esse valor varia de acordo com a sequência de bits do documento, e como cada caractere tem uma composição binária, qualquer mudança no arquivo original fará com que o valor hash seja diferente e a assinatura se torne inválida.

\subsubsection{A estrutura de certificação digital no Brasil}

A assinatura e o certificado digital são os elementos principais da arquitetura de certificação digital, mas não são os seus únicos elementos. Como visto anteriormente, no modelo de tacógrafo europeu foi necessário implementar toda uma infra-estrutura de gerenciamento de chaves e mensagens de certificação. Essa infra-estrutura compreende protocolos de segurança, políticas de uso, entidades certificadoras, salas-cofre e autoridades 
de registro, que seguem diretrizes e normas técnicas determinadas por uma entidade ou comitê gestor.

Essa cadeia é chamada de ICP - Infra-estrutura de Chaves Públicas ou PKI em países de língua inglesa. Uma empresa pode criar sua própria ICP. No Brasil o Governo Federal adotou sua própria política de uso de certificados e assinaturas digitais e criou sua infraestrutura de chaves públicas chamada ICP-Brasil.

Os elementos que compõem a teia de confiança da certificação digital tanto para órgãos públicos quanto para a iniciativa privada são: AC Raiz - Autoridade Certificadora Suprema que autoriza as operações das autoridades certificadoras, AC - Autoridades Certificadoras que emitem o certificado digital das autoridades de registro e de autoridades certificadoras por ela credenciadas, além de atestar a identidade do titular do documento; AR Autoridades de Registro que comprovam fisicamente a identidade do usuário, podendo auxiliá-lo na geração do par de chaves, solicita os certificados a uma AC e entregam o cartão inteligente ao titular; Certificados digitais e Assinaturas digitais são documentos eletrônicos que comprovam a identidade do usuário e do equipamento nas transações eletrônicas. A Figura 2-15 apresenta a estrutura da certificação digital no Brasil.

A ICP-Brasil prevê a emissão de oito tipos de certificado. São duas séries de certificados, com quatro tipos cada. A série A (A1, A2, A3 e 4) reúne os certificados de assinatura digital, utilizados na confirmação de identidade na Web, em e-mail, em redes privadas virtuais e em documentos eletrônicos com verificação da integridade de suas informações. A série $\mathrm{S}$ (S1, S2, S3 e S4) reúne os certificados de sigilo, que são utilizados na codificação de documentos, de bases de dados, de mensagens e de outras informações eletrônicas sigilosas. Os oito tipos são diferenciados pelo uso, pelo nível de segurança e pela validade (CERTISIGN, 2010). 
Estrutura da certificação digital no Brasil

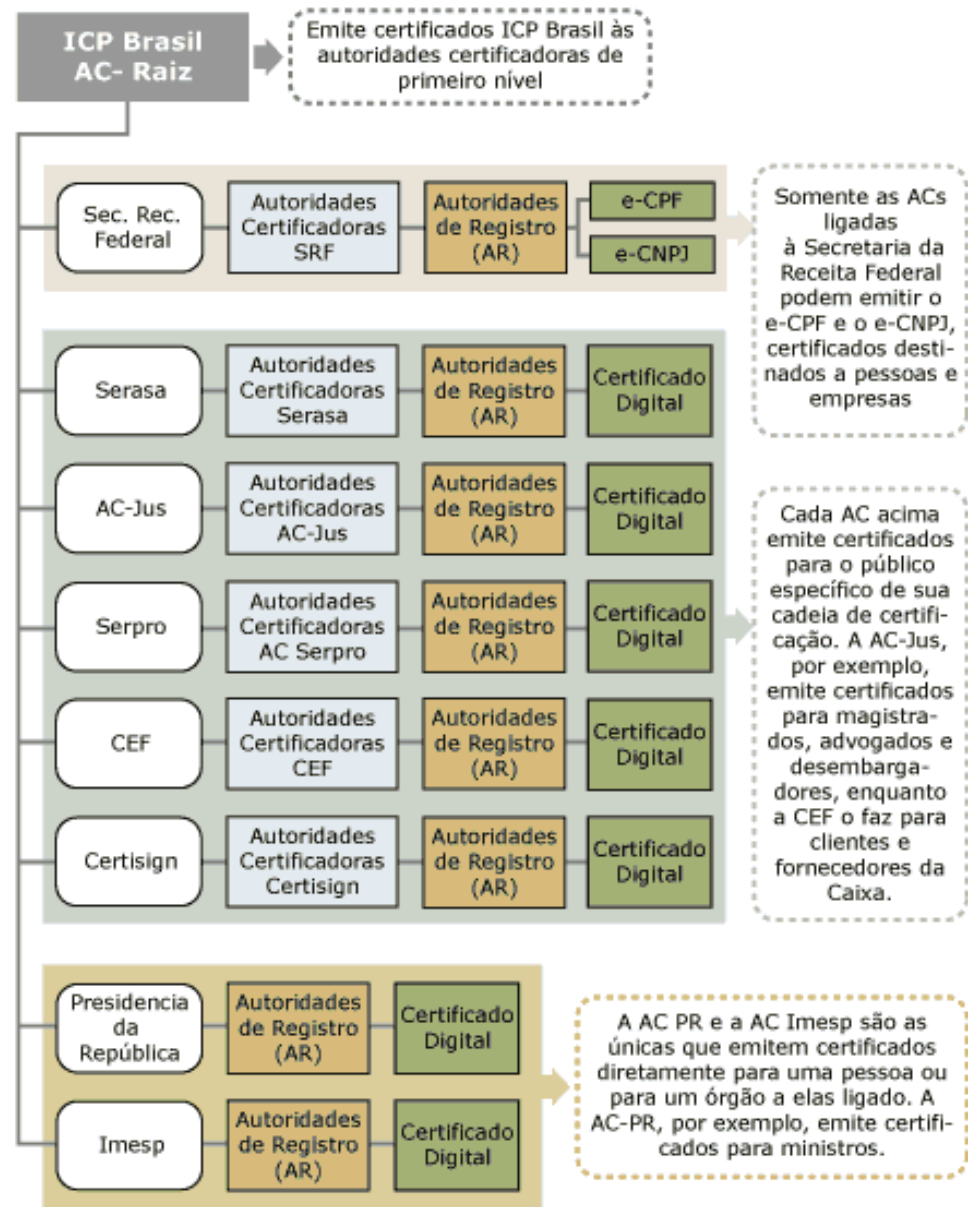

Legenda: $\square$ AC 1Nivel $\square$ AC 20Nivel

Figura 2-15 - Organograma da Autoridade de Certificação Brasileira (CERTISIGN, 2010).

Nos certificados do tipo A1 e S1, os mais simples, as chaves privadas ficam armazenadas em arquivos eletrônicos. Nos tipos A2, A3, A4, S2, S3 e S4, as chaves privadas e as informações referentes ao certificado ficam armazenadas cartões inteligentes.

\subsubsection{O e-CPF - Cadastro de Pessoa Física eletrônico}

O e-CPF é um certificado digital emitido pelas autoridades certificadoras como, por exemplo, o Serasa entre outros. O e-CPF do tipo A3 pode ser gerado em um cartão inteligente ou uma mídia criptográfica e tem validade de três anos. A imagem da Figura 2-16 mostra a aparência de um cartão inteligente e-CPF (SERASA, 2010). O cartão inteligente segue o padrão ISO-7816, e exibe em sua face frontal o nome e número de CPF do titular, o chip criptográfico onde estão armazenados os dados do titular e a chave privada associada àquele 
certificado, e o logo da autoridade certificadora. No verso estão os logos da Receita Federal e da ICP-Brasil, além de mensagens informativas quanto à revogação do certificado em caso de perda ou roubo do cartão.

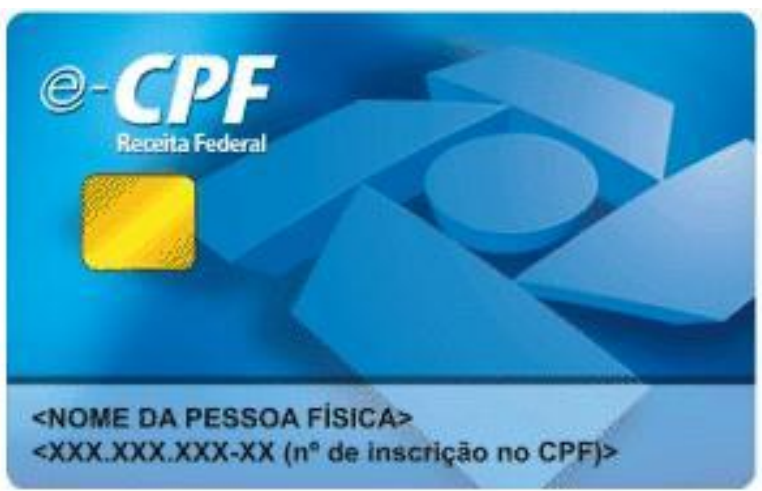

Figura 2-16 - Cartão inteligente do e-CPF (CERTISIGN, 2010).

\subsection{O Sistema nacional de identificação automática de veículos - SINIAV}

No momento em que este trabalho foi escrito, as autoridades de trânsito e os fabricantes de equipamentos eletrônicos no Brasil encontravam-se em discussão para delimitar os requisitos do projeto SINIAV - Sistema Nacional de Identificação Automática de Veículos.

Sua proposta prevê a instalação de uma etiqueta inteligente, chamada de placa eletrônica, em cada veículo em circulação no país. Esta placa eletrônica possui em seu interior um circuito eletrônico semelhante à dos cartões inteligentes discutidos anteriormente, com o diferencial de estabelecer comunicação com o equipamento de leitura através de ondas eletromagnéticas. O que permite a comunicação entre leitor e etiqueta sem contato e em movimento, bastando para isso que existam condições de propagação eletromagnética.

A alimentação para o funcionamento do circuito eletrônico no interior da placa eletrônica pode ser provida de duas maneiras, através de uma bateria, que acrescenta tamanho e peso ao dispositivo além do inconveniente da manutenção periódica, e o sistema de alimentação por indução. Neste último, a etiqueta é alimentada através do campo magnético 
gerado durante a leitura dos dados. A Figura 2-17 exibe o diagrama elétrico típico de sistemas de alimentação por indução para etiquetas eletrônicas.

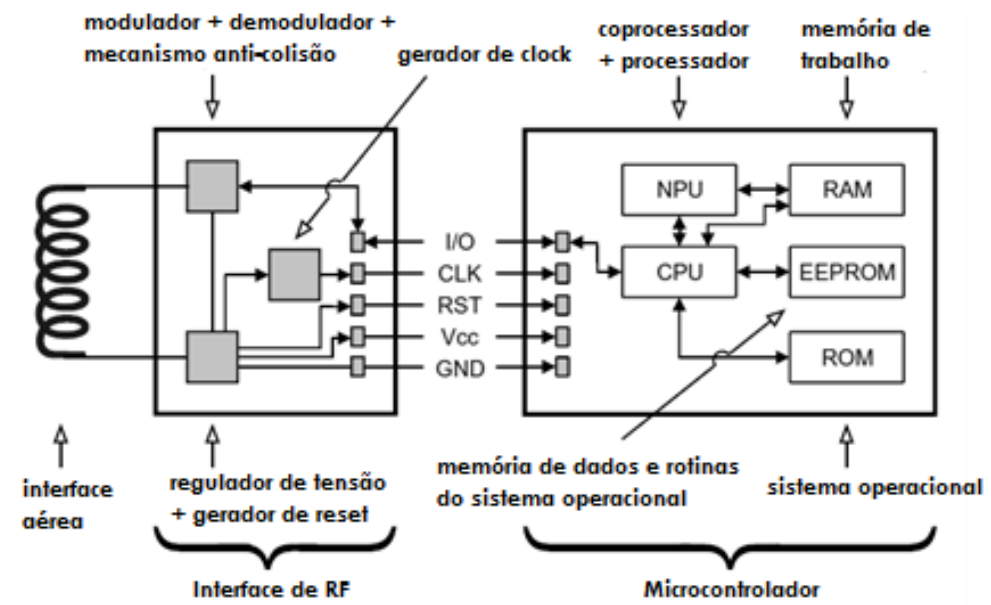

Figura 2-17 Diagrama elétrico de etiqueta inteligente (WOLFGANG R. E WOLFGANG E., 2002).

A comunicação de dados entre a placa eletrônica e o equipamento de leitura é realizada através de comandos criptografados que incluem a autenticação tanto da placa quando do equipamento de leitura. Esse procedimento visa impedir a falsificação não só das placas eletrônicas, o que dado às tecnologias envolvidas é bem difícil, mas também dos leitores impedindo que leitores não oficiais possam coletar dados de veículos de maneira não oficial para fins irregulares. A Figura 2-18 exibe a placa eletrônica, que possui dimensões idênticas aos cartões inteligentes. Nota-se a bobina de indução que circunda as bordas do cartão.

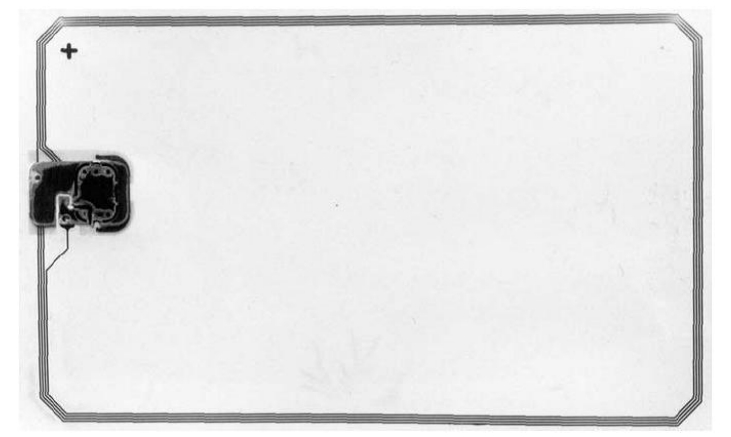

Figura 2-18 - Aspecto da etiqueta eletrônica (WOLFGANG R. E WOLFGANG E., 2002).

Em seu sistema interno a placa eletrônica adotada no SINIAV armazena uma série de informações, entre elas um código único de identificação do veículo. Essa tecnologia 
permitirá uma infinidade de automatizações e serviços para o condutor e também para os órgãos de fiscalização, donde poderão advir novas técnicas de e-enforcement. Exemplo dessas novas iniciativas é o modelo de aferição de velocidade onde vários leitores de placas eletrônicas espalhadas pelas vias fazem a leitura das etiquetas correlacionando-as com o instante da leitura. Comparando-se a leitura entre dois pontos distintos e conhecendo-se a distância entre eles, permite inferir a velocidade média no trajeto e aplicação automática de sanções aos que ultrapassarem os limites. A Figura 2-19 exibe um exemplo de aplicação do SINIAV.

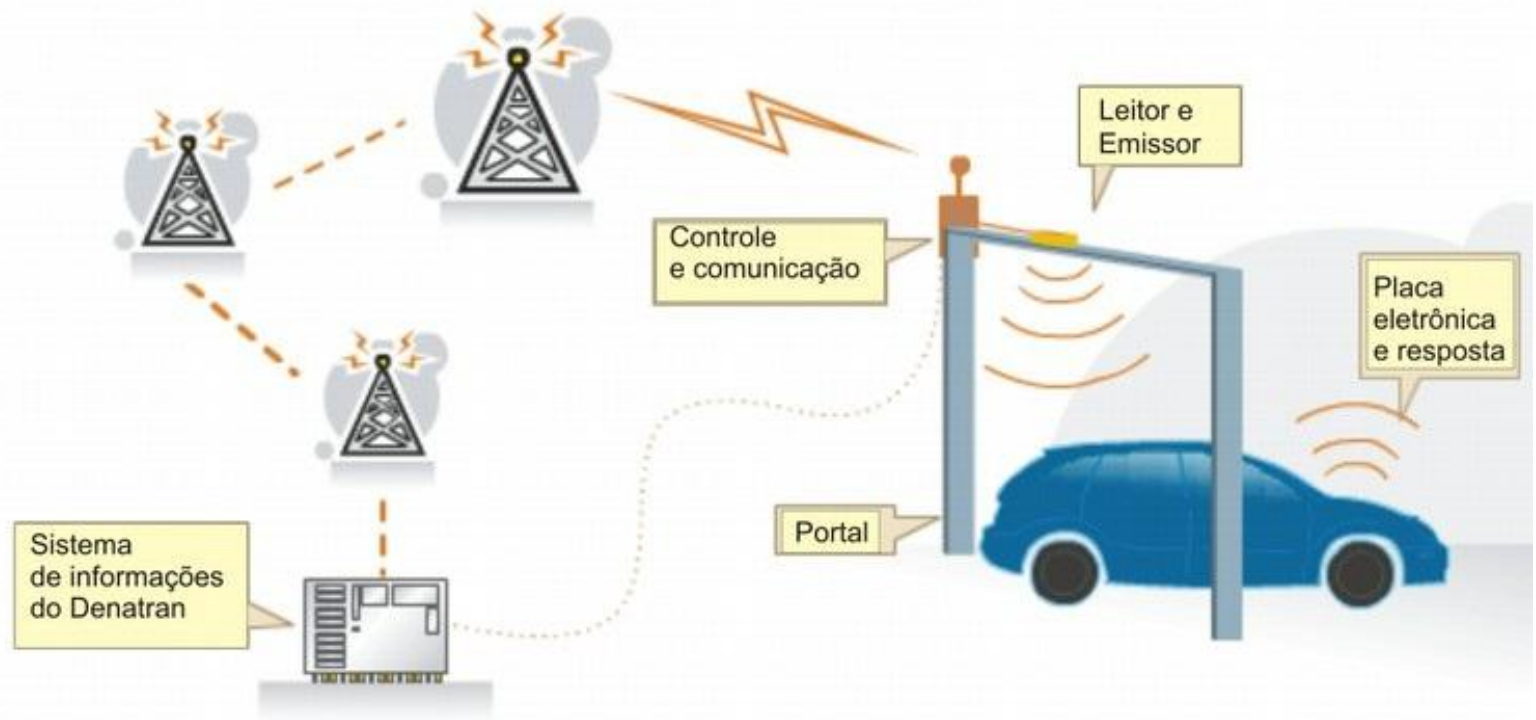

Figura 2-19 - Aplicação do SINIAV (CEFTRU, 2010).

Alguns setores da sociedade acusam este sistema de interferir no direito a privacidade das pessoas, que passariam a deixar registrados os locais por onde trafegam com seus veículos. Este movimento tem ganhado força e pode atrasar a aplicação do projeto, mas considera-se que a sua adoção é questão de tempo e os problemas com a confidencialidade dos dados resolvidos com técnicas de criptografia e acesso restrito.

Thober et al. (2009) apresentaram uma relação detalhada dos requisitos técnicos que nortearão o desenvolvimento e a implantação do projeto SINIAV, a saber: 


\begin{abstract}
"Deve possibilitar a operação integrada com outros equipamentos de campo, através de interface aberta e conhecida como interface serial, paralela, USB ou ethernet; Deve ter desempenho de leitura de pelo menos $99,90 \%$ (noventa e nove vírgula noventa por cento) das passagens dos veículos equipados com as placas eletrônicas; Deve ter capacidade de leitura e gravação de dados nas placas eletrônicas a uma distância mínima de 5 metros; Deve permitir a leitura de dados nas placas instaladas em veículos que estejam trafegando até $160 \mathrm{~km} / \mathrm{h}$, no mínimo; Deve permitir a gravação de dados nas placas instaladas em veículos que estejam trafegando até 80 $\mathrm{km} / \mathrm{h}$, no mínimo; Deve resistir a intempéries climáticas e poder funcionar a céu aberto, com proteção física mínima de IP 65 conforme a norma NBR 9883 da ABNT (Associação Brasileira de Normas Técnicas).”
\end{abstract}

Quanto às placas eletrônicas:

"Devem ter capacidade mínima de armazenamento de 1024 bits de informação, sem limite máximo de memória; Devem possibilitar sua fixação nos veículos de tal forma que se tornem fisicamente inoperantes quando removidas da sua localização original; Devem ser fixadas no lado interno do pára-brisa dianteiro dos veículos, conforme janela de comunicação de dados informada pelo fabricante do veiculo; $\mathrm{Na}$ ausência desta informação, deverão ser fixadas no lado interno do pára-brisa dianteiro dos veículos, conforme determinações do órgão executivo de trânsito do Estado, ou do Distrito Federal, onde estiver registrado o veículo; No caso de veículos que não possuam pára-brisa, a placa eletrônica deverá ser fixada em local que garanta o seu pleno funcionamento. Devem ter capacidade de serem lidas em qualquer condição climática, sem prejuízo da confiabilidade de 99,90\% (noventa e nove vírgula noventa cento) de identificação do veículo; A unicidade numérica das placas eletrônicas fornecidas deve ser garantida através de processo controlado pelo DENATRAN."

Relativo à frequiência de operação do sistema SINIAV, Thober et al. (2009) informam que os leitores devem operar na faixa de $915 \mathrm{MHz}$ até $928 \mathrm{MHz}$, em canais de transmissão com uma largura de banda de $500 \mathrm{kHz}$. Essa faixa de freqüências está contida na banda ISM de $900 \mathrm{MHz}$, ficando por isso, livre da obrigatoriedade de licenciamento da ANATEL.

A memória interna da placa eletrônica é dividida em 8 páginas e estas em campos de uso pré-determinado. Estes campos fornecem uma identificação detalhada das características de registro do veículo, do órgão emissor, e da pessoa responsável pela sua programação. A Erro! Fonte de referência não encontrada. apresenta detalhadamente a estrutura dos mapas de memória da placa eletrônica. Note-se foram reservadas porções de memória prevendo um aumento considerável da frota. Além disso, as últimas três páginas da memória são reservadas ao desenvolvimento de futuras aplicações que poderão ser exploradas por outras empresas para oferecimento de serviços diferenciados. Isso servirá como um forte incentivo à implantação do SINIAV. 
Tabela 2-1 - Mapa de memória da placa eletrônica do SINIAV.

\begin{tabular}{|c|c|c|c|}
\hline Página & Campo & Tamanho & Formação \\
\hline \multirow{7}{*}{1} & Número Serial Único & 64 & Serial que identifica unicamente um veículo \\
\hline & Placa do Veículo & 40 & $\begin{array}{l}\text { Reserva para placa de } 4 \text { letras e cinco dígitos } \\
\text { numéricos }\end{array}$ \\
\hline & Categoria do Veículo & 8 & 2 dígitos numéricos \\
\hline & Espécie do Veículo & 4 & 1 dígito numérico \\
\hline & Tipo de Veículo & 8 & 2 dígitos numéricos \\
\hline & $\begin{array}{l}\text { Veículo de Frota } \\
\text { Estrangeira }\end{array}$ & 1 & Condição verdadeiro ou falso \\
\hline & Reservado DENATRAN & 3 & Reserva \\
\hline \multirow{3}{*}{2} & Identificação do Emissor & 64 & País e estado \\
\hline & $\begin{array}{l}\text { Matricula do Agente } \\
\text { Programador }\end{array}$ & 32 & Número de matrícula do agente programador \\
\hline & $\begin{array}{l}\text { Data e Hora da } \\
\text { Programação }\end{array}$ & 32 & $\begin{array}{l}\text { Data e hora baseado no padrão UNIX para } \\
\text { representar data e hora em segundos a partir de } 01 \text { de } \\
\text { Janeiro de } 1970\end{array}$ \\
\hline 3 & Número do Chassi & 128 & $\begin{array}{l}17 \text { caracteres alfanuméricos do chassi mais } 4 \\
\text { caracteres reservados }\end{array}$ \\
\hline \multirow{4}{*}{4} & Controle de Manufatura & 32 & Reservado a manufatura \\
\hline & RENAVAM & 40 & 9 dígitos numéricos mais um dígito de reserva \\
\hline & Código Marca/Modelo & 24 & 6 dígitos numéricos \\
\hline & Área Reservada & 32 & Área reservada a aplicações do DENATRAN \\
\hline 5 & $\begin{array}{l}\text { Área Reservada para outras } \\
\text { aplicações do DENATRAN }\end{array}$ & 128 & $\begin{array}{l}\text { Área reservada a aplicações autorizadas pelo } \\
\text { DENATRAN }\end{array}$ \\
\hline $6-7-8$ & $\begin{array}{l}\text { Uso aberto para outras } \\
\text { aplicações }\end{array}$ & 384 & 6 Blocos de 64 bits de uso livre \\
\hline
\end{tabular}

\subsection{Tecnologias para conexões sem fios}

\subsubsection{O Modelo TCP/IP}

Tanembaum (1997) explica que no final dos anos 1970, o governo dos Estados Unidos da América financiou um grande esforço no meio acadêmico com o intuito de padronizar os equipamentos de comunicação em rede. Esse esforço tinha como objetivo inicial oferecer um mínimo de interoperabilidade entre equipamentos de diferentes fabricantes e oferecer alta disponibilidade às redes de comunicação militares. $\mathrm{O}$ resultado deste esforço foi um pacote de protocolos de comunicação conhecido pelo acrônimo TCP/IP - Transport Control Protocol / Internet Protocol. 
Sua adoção no meio acadêmico foi quase instantânea, pois o pacote de protocolos estava disponível no sistema operacional UNIX da Universidade de Berkeley, largamente adotado na época, além de ser gratuito. Um dos principais motivos deste sucesso era o seu modelo de desenvolvimento em camadas sobrespostas, ou camadas de abstração, que ficou conhecido como pilha ou modelo TCP/IP. Posteriormente a pilha TCP/IP foi utilizada na Arpanet, projeto que anos depois deu origem ao que hoje conhecemos como Internet.

Neste modelo, os diferentes protocolos que compõem o pacote TCP/IP foram divididos segundo uma hierarquia de funcionalidade. Os protocolos que dependem logicamente de si mesmos ocupam nas camadas inferiores, e os protocolos que dependem destes primeiros ficam em níveis superiores. Finalmente estes protocolos foram agrupados quanto a sua similaridade na dependência de protocolos inferiores, e arranjados em quatro camadas. A Figura 2-20 - Representação do modelo TCP/IP (TANEMBAUM, 1997).Figura 2-20 exibe uma representação do modelo TCP/IP.

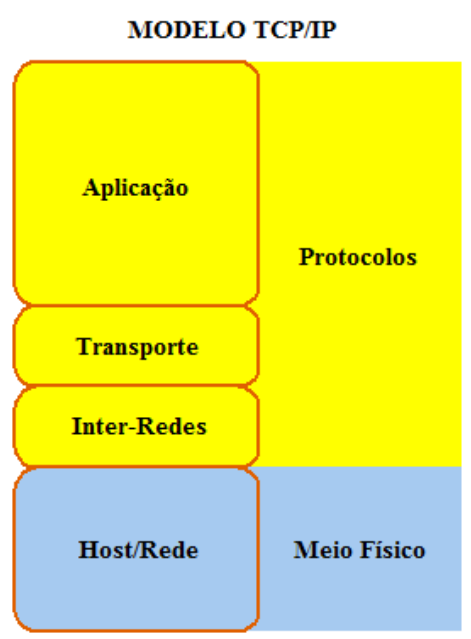

Figura 2-20 - Representação do modelo TCP/IP (TANEMBAUM, 1997).

A camada de Aplicação agrupou os protocolos que oferecem funcionalidade final aos seus usuários. Exemplos deles são o HTTP para a transferência de hipertexto e SMTP para a transferência de correio eletrônico, entre outros. Na camada de transporte ficaram os protocolos que cuidam da adequação dos dados a serem transmitidos, manipulando-os de 
forma conveniente, e do estabelecimento, manutenção e encerramento das conexões de rede. Seus protocolos são o TCP - Transport Control Protocol e o UDP - User Datagram Protocol. Já a camada de Inter-Redes cuida da escolha do percurso para a entrega das informações provenientes das camadas superiores, conhecido como roteamento. Seu principal protocolo é o IP - Internet Protocol. Já a última camada, a Host/Rede é a responsável por controlar o acesso ao meio de transmissão e de transformar impulsos físicos de toda ordem em informações lógicas para as camadas superiores. Esta camada é a mais abrangente, pois permitiu que diferentes meios físicos de transmissão pudessem compartilhar a mesma estrutura de protocolos. Basta que o fabricante altere os protocolos de seu dispositivo de meio físico tornando-o compatível como a camada de Inter-Rede, e todo o resto da pilha de protocolos será capaz de utilizá-lo.

Esse modelo foi muito bem sucedido, mas a camada de Host/Rede rapidamente se tornou complexa dada a grande quantidade de meios físicos de transmissão disponíveis. Trabalhando em uma outra frente, os fabricantes de equipamentos de rede reuniram-se sobre a égide da IEEE - Institute of Electrical and Electronic Engineers, para padronizar os projetos de dispositivos físicos de rede.

\subsubsection{Os padrões de rede IEEE}

Na IEEE, os padrões ou grupos de normatização são identificados por números. Quando algum fabricante desenvolve uma nova tecnologia de rede, ou, quando surge uma demanda por um novo serviço de rede que seja incompatível com os padrões estabelecidos, o IEEE abre um novo grupo de trabalho que poderá dar origem a um novo padrão. Caso contrário, se a nova tecnologia ou demanda for compatível com a norma existente, ela poderá receber um subgrupo de trabalho ou uma revisão. 
Segundo Tanembaum (1997) o padrão físico de rede mais difundido e utilizado no mundo é o IEEE 802. Dentre deste grupo ou norma existem diversos subprojetos que tratam de diferentes técnicas e meios físicos de transmissão. O organograma da Figura 2-21 exibe a organização destes subprojetos dentro da estrutura do IEEE 802. O projeto 802.2 cuida da camada de link lógico ou LLC, e o projeto 802.1 cuida das conexões de ponte. Juntas estas camadas são as responsáveis por manter a interoperabilidade entre a camada de Inter-Redes do TCP/IP e os diferentes meios físicos de transmissão. Deve-se entender, pois que o projeto 802 como um todo está contido na camada Host/Rede do modelo TCP/IP.

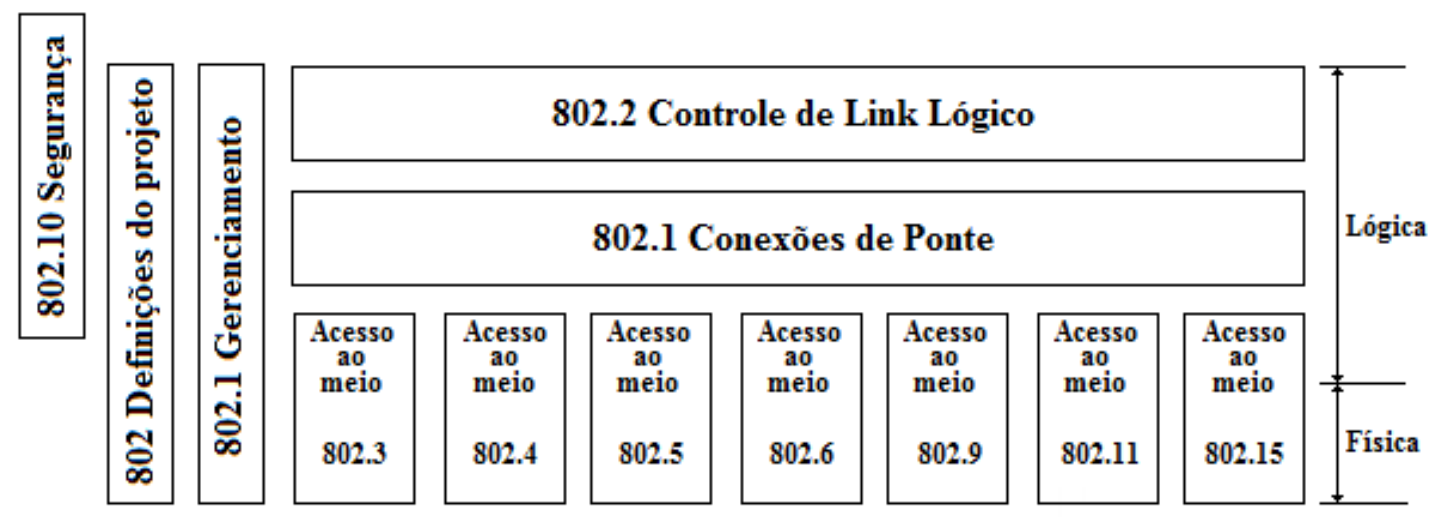

Figura 2-21 - Organização do projeto IEEE802 (BOWLER, 2010).

Voltando à Figura 2-21 observa-se que abaixo das camadas 802.2 e 802.1 estão distribuídos diversos subprojetos. Cada um deles tratando de diferentes meios físicos de transmissão. O projeto relevante a este trabalho é o IEEE 802.11, que trata de conexões de rede locais sem fio. Note-se que devido a adoção do protocolo TCP/IP para o projeto do RIIVT garantirá interoperabilidade completa com uma infinidade de dispositivos de rede, bastando para tal que a interface de rede seja compatível com a estrutura TCP/IP e IEEE 802.

\subsubsection{O padrão 802.11}

Também o subprojeto IEEE 802.11 têm as suas especificidades. A cada mudança tecnológica que incremente o seu desempenho ou aumente as suas funcionalidades é lançada uma nova revisão do mesmo. As revisões são identificadas por uma letra associada ao código 
do projeto. A Figura 2-22 exibe um panorama das primeiras revisões do padrão IEEE 802.11. Observa-se que o padrão contempla as frequiências ISM de 2.4 e $5 \mathrm{GHz}$, além das técnicas de modulação FHSS, DSSS, e OFDM.

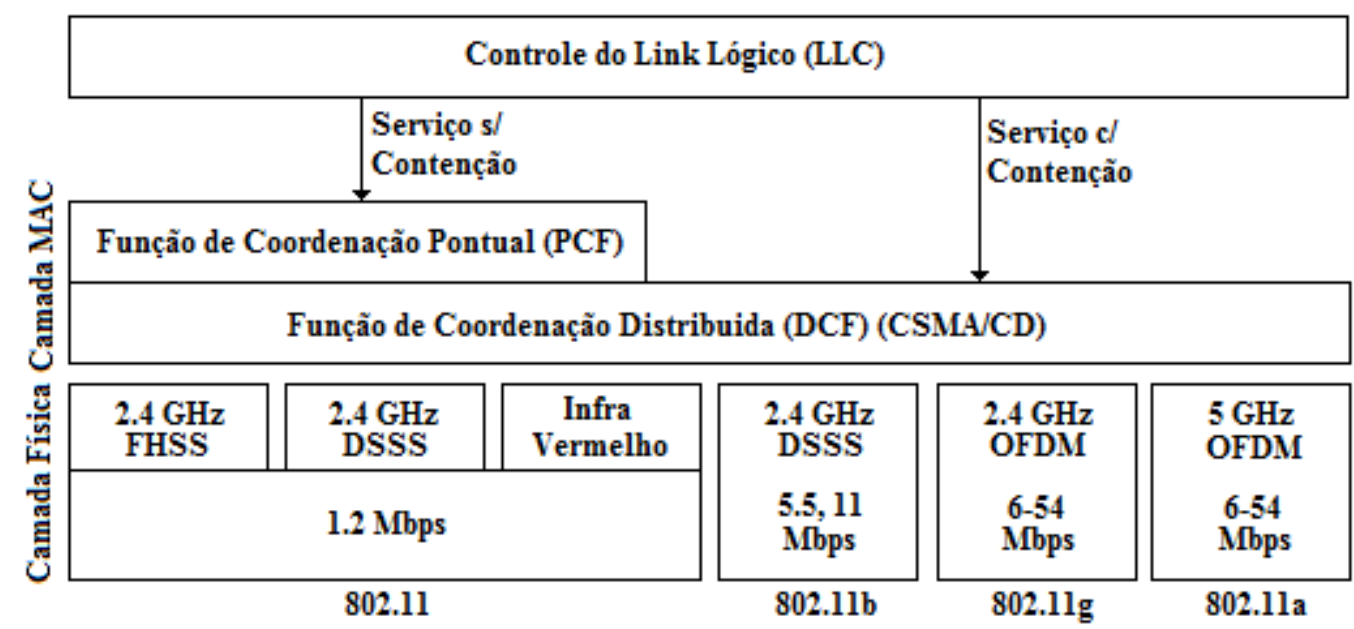

Figura 2-22 - Primeiras revisões da norma 802.11 (IEEE802, 2010).

Atualmente esta tecnologia é muito empregada em redes locais de empresas e residências na freqüência de $2.4 \mathrm{GHz}$, pois é livre da obrigatoriedade de licenciamento para fins não comerciais. Além disso, é grande a quantidade de fabricantes o que levou a redução de custos e facilidade de instalação. Pode-se dizer que as redes sem fio IEEE 802.11 são hoje consideradas como um eletrodoméstico.

\subsubsection{Aplicações automotivas das redes sem fios}

Palazzi, Rocetti e Ferretti (2009) elencaram outras características comumente necessárias às aplicações que fazem uso de conexões sem fios entre veículos e a infraestrutura das rodovias. Estas características estão descritas na Tabela 2-2.

Tabela 2-2 - Requisitos necessários a uma tecnologia de comunicação automotiva.

\begin{tabular}{|l|c|}
\hline \multicolumn{1}{|c|}{ Requisito } & Valor Típico \\
\hline Fonte das mensagens & De um a centenas de veículos \\
\hline Tamanho das mensagens & 20 a 200 bytes \\
\hline Taxa das mensagens & De 1 por dia a 3 por segundo \\
\hline Tamanho da sessão & Poucos segundos \\
\hline Métrica principal & Tempo de entrega das mensagens \\
\hline Métrica secundária & Confiabilidade da entrega \\
\hline
\end{tabular}


Observa-se então que a tecnologia de conexão adotada precisa ser capaz de manipular as mensagens de centenas de veículos, a uma taxa relativamente alta, em sessões de curta duração, e que entreguem as mensagens de forma rápida e confiável.

Soriano (2001), explica que a tecnologia para a conexão sem fios entre veículos e equipamentos rodoviários surgiu nos EUA, no início da década de 90, para automatizar o processo de pagamento em pedágios. Esta tecnologia foi chamada de DSRC - Dedicated Short Range Communications e operava nas bandas não licenciadas de $915 \mathrm{MHz}$ chamada de LMS - Location and Monitoring Services, e 2.4 GHz chamada de ISM - Industrial Scientific and Medical. Sua adoção foi pequena, pois fazia uso de protocolos de comunicação proprietários, o que impedia que dispositivos adotados por uma concessionária de rodovia não funcionasse nos terminais de outra.

A iniciativa de padronização veio em 1999 quando a FCC - Federal Communication Commission, orgão de regulamentação dos EUA, especificou uma faixa de $75 \mathrm{MHz}$ dedicada ao DSRC na freqüência de $5.9 \mathrm{GHz}$, dedicada às comunicações públicas e privadas entre veículos, e entre veículos e equipamentos da rodovia. A Figura 2-23 apresenta os canais que compõem a especificação DSRC que cobre a freqüência de 5,825 Ghz e 5,925 GHz.

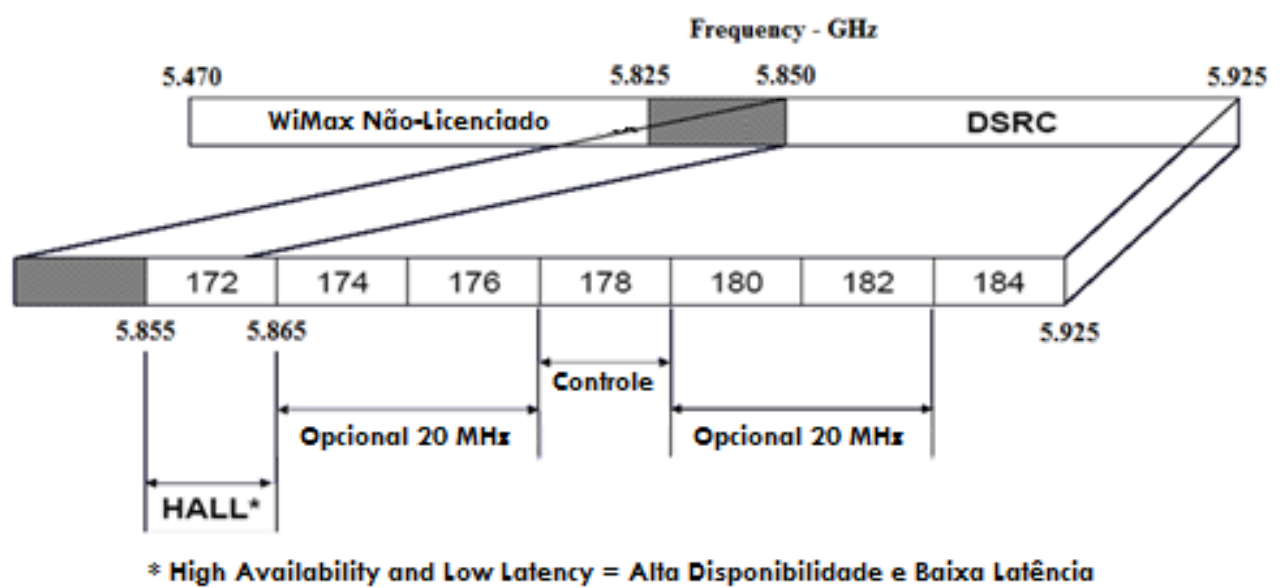

Figura 2-23 - Descrição dos canais da tecnologia DSRC (INTELIDRIVE, 2009). 
A especificação compreende sete canais, sendo um deles dedicado ao controle da conexão, outro dedicado à comunicação de alta disponibilidade e baixa latência, e cinco canais de uso geral (INTELIDRIVE, 2009).

O termo latência neste caso faz menção ao tempo que uma unidade de informação leva para percorrer todo o canal de comunicação. O canal de baixa latência da especificação DSRC é dedicado a mensagens de emergência em casos que envolvam o risco de vida.

Essa padronização criou iniciativas de pesquisa na área de ITS nos EUA, que resultou nas VANET’S - Vehicular Ad hoc Networks. Segundo Silva (2008), as VANET'S consistem dos laços de comunicação entre os veículos e a estrada RVC - Road Vehicle Communication, e entre os próprios veículos, IVC - Inter Vehicle Communication. As pesquisas da VANET's deram origem ao projeto INTELIDRIVE (2009) que visa desenvolver rodovias inteligentes nos EUA.

A padronização mundial de um sistema de comunicação entre veículos e infraestrutura rodoviária tem sido liderada pela IEEE - Institute of Electrical and Electronic Engineers, que definiu o projeto WAVE - Wireless Access in Vehicular Environments, ou IEEE 802.11p, que é o código do projeto. Este projeto visa adaptar o projeto IEEE 802.11a para ser compatível com as necessidades das VANET’s.

O principal ponto positivo da padronização IEEE é que toda a expertise obtida nos anos de desenvolvimento do padrão de redes sem fios IEEE 802 para computadores pessoais é diretamente aproveitada no projeto WAVE, evitando o desenvolvimento de novos protocolos e fomentando o desenvolvimento de produtos de baixo custo.

Silva (2008), explica que esta nova especificação é bastante semelhante à anterior, operando em sete canais de $10 \mathrm{MHz}$ de largura de banda cada, ocupando a mesma faixa no espectro. A Figura 2-24 exibe a nomenclatura dos canais da especificação WAVE. 


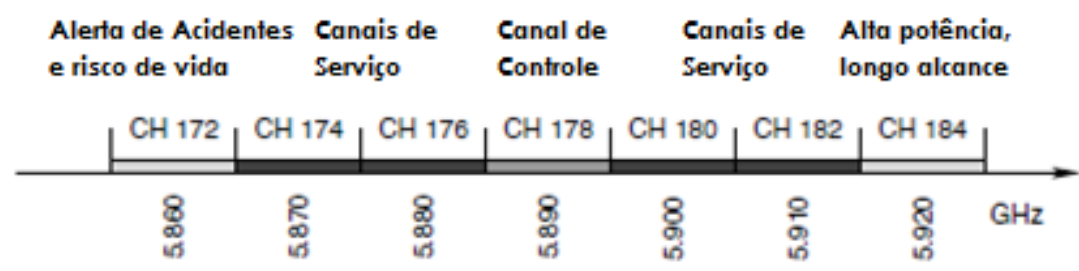

Figura 2-24 - Nomenclatura dos canais WAVE (EICHLER, 2007).

Diferentes canais não podem ser utilizados ao mesmo tempo, entretanto, cada estação pode alterar constantemente entre o canal de controle e os canais de serviços ou o canal de segurança. Por questões de segurança, o tempo de utilização de um canal de serviço somado a um canal de controle não pode ser maior que 100ms. A WAVE trabalha com uma taxa de transferência que varia entre 3 e $27 \mathrm{Mbps}$ e foi projetado para trabalhar com um alcance menor que $1 \mathrm{Km}$. Tal padrão foi pensado considerando-se velocidade de deslocamento dos veículos maior que $110 \mathrm{~km} / \mathrm{h}$. Essa padronização atende perfeitamente os requisitos especificados por Palazzi, Rocetti e Ferretti (2009), acima. A Tabela 2-3 foi formulada por Dulmage et al. (2010), que apresentam um comparativo entre as diversas tecnologias de comunicação disponíveis para aplicação veicular.

Tabela 2-3 - Comparativo das tecnologias de comunicação veicular.

\begin{tabular}{|l|l|l|l|l|} 
& $\begin{array}{l}\text { WA VE - } \\
\text { IEEE802.11p }\end{array}$ & $\begin{array}{l}\text { Wi-Fi } \\
\text { IEEE802.11 }\end{array}$ & $\begin{array}{l}\text { Celular } \\
\text { GSM }\end{array}$ & $\begin{array}{l}\text { WiMax IEEE } \\
\text { 802.16e }\end{array}$ \\
\hline Taxa de Dados & $3 \sim 27 \mathrm{Mbps}$ & $1-54 \mathrm{Mbps}$ & $<2 \mathrm{Mbps}$ & $1-32 \mathrm{Mbps}$ \\
\hline Latência & $<50 \mathrm{~ms}$ & $>1 \mathrm{segundo}$ & $>1 \mathrm{segundo}$ & $>1 \mathrm{segundo}$ \\
\hline Alcance & $<1 \mathrm{~km}$ & $<400 \mathrm{~m}$ & $<10 \mathrm{~km}$ & $<15 \mathrm{~km}$ \\
\hline Mobilidade & $\sim 110 \mathrm{~km} / \mathrm{h}$ & $\sim 8 \mathrm{~km} / \mathrm{h}$ & $\sim 110 \mathrm{~km} / \mathrm{h}$ & $\sim 110 \mathrm{~km} / \mathrm{h}$ \\
\hline Banda do Canal & $10 \mathrm{MHz}$ & $20 \mathrm{MHz}$ & $<3 \mathrm{MHz}$ & $<10 \mathrm{MHz}$ \\
\hline Banda do Sistema & $5,86 \mathrm{GHz}$ & $2.4 \mathrm{e} 5.2 \mathrm{GHz}$ & $0.8 \mathrm{e} 1.9 \mathrm{GHz}$ & $2.5 \mathrm{Ghz}$ \\
\hline
\end{tabular}




\section{MATERIAIS E MÉTODOS}

O sistema embarcado proposto neste trabalho consiste na reunião de diversas tecnologias, algumas delas maduras, a fim de constituir um RIIVT que atenda as premissas técnicas fixadas em lei, mas promovendo inovações a fim de evitar fraudes e diminuir custos. A concepção de cada subsistema será apresentada de maneira modular, tal qual o projeto, de maneira que seja possível avaliar o desempenho de cada subsistema isoladamente. Já os aperfeiçoamentos decorrentes da realização dos ensaios serão apresentados no Capítulo 4 Resultados, mais adiante.

\subsection{O módulo receptor GPS}

Para a recepção dos sinais GPS no RIIVT proposto foi selecionado um módulo receptor integrado, modelo BU-353RB da empresa GlobalSAT. Este que inclui antena cerâmica de microstrip para recepção dos sinais de satélite e um processador GPS dedicado baseado no chip SIRF Star III.

Suas características principais incluem uma precisão de 5 metros, sensibilidade de recepção de sinal de $-159 \mathrm{dBm}$, capacidade de rastreamento de até 20 satélites simultâneos e 
limites operacionais de 18.000 metros de altitude, aceleração de até $4 \mathrm{~g}$ e velocidade de até $515 \mathrm{~m} / \mathrm{s}$.

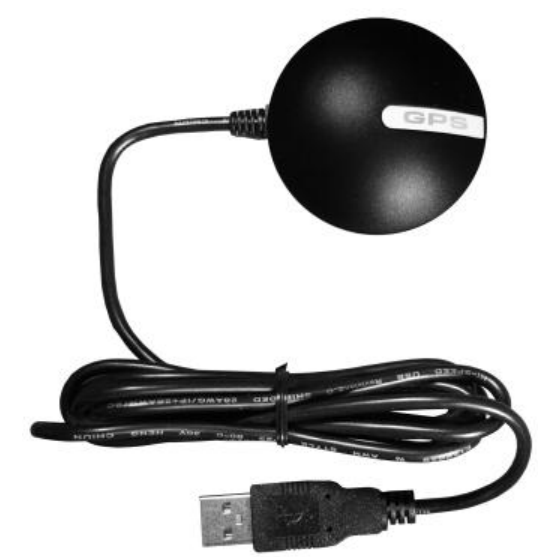

Figura 3-1 - Módulo receptor de GPS BU-353RB.

O módulo GPS se conecta ao restante do sistema através do barramento USB, alimentando-o com as informações de localização geográfica obtidas com o processamento das informações correlacionados dos satélites. A transferência destas informações se dá através do protocolo serial NMEA 0183 - National Marine Electronics Association, que entrega as informações ao barramento USB na medida em que são determinadas, a uma velocidade 4800 bps - bits por segundo, utilizando-se mensagens compostas por caracteres ASCII - American Standard Code for Information Interchange. A imagem da Figura 3-2 apresenta o diagrama de blocos que compõem o chip SIRF III do módulo GPS.

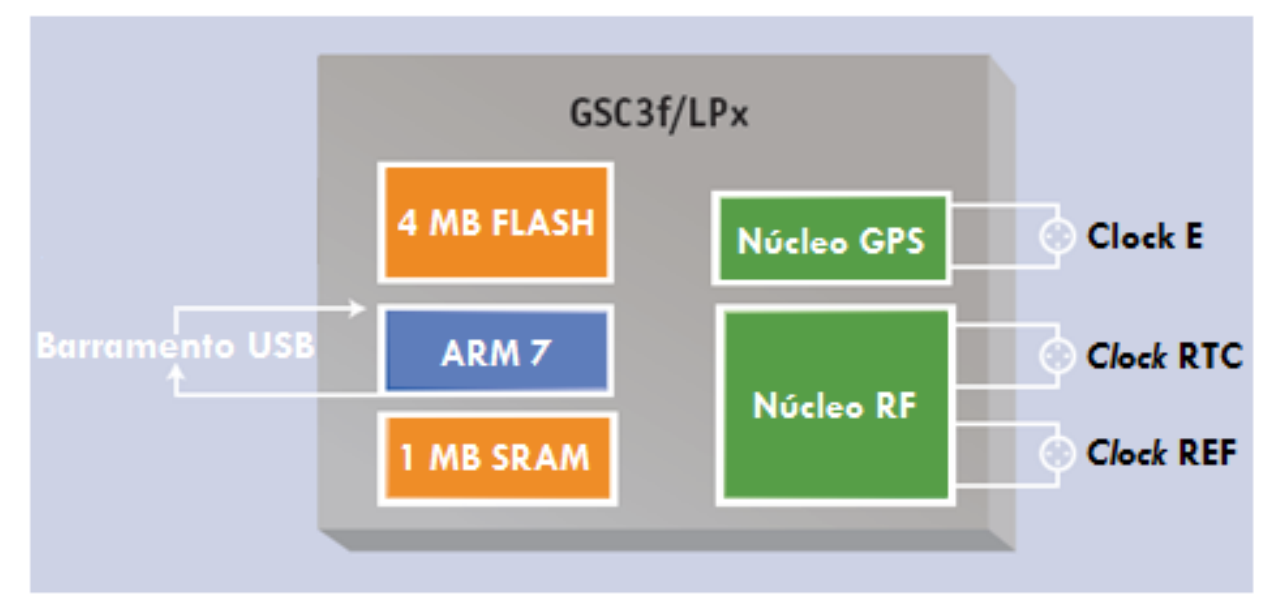

Figura 3-2 - Diagrama de blocos do chip SIRF III (SIRF, 2008). 


\subsection{O subsistema de criptografia}

As finalidades do subsistema de criptografia são: identificar de maneira inequívoca e a prova de fraudes o condutor do veículo a fim de se contabilizar a jornada de trabalho ao volante; assinar digitalmente os arquivos de registro de condução para impedir a adulteração dos mesmos; permitir a transferência de arquivos criptografados do RIIVT mantendo-se a privacidade do condutor e da empresa de transporte; identificar de maneira inequívoca a autoridade policial que tenha fiscalizado o condutor; e identificar de maneira inequívoca a empresa que tenha realizado manutenção técnica no equipamento.

Como já explicado do Capitulo 2, a comunidade européia atendeu aos seus requisitos de criptografia instituindo uma estrutura de certificação e confiança destinados unicamente a atender a norma legal do tacógrafo.

Por acreditar que a criação de uma nova estrutura de certificação onera o Estado, promovendo o aumento de complexidade, gastando tempo precioso e prejudicando o cidadão, passou-se a buscar uma alternativa eficaz para atender os requisitos elencados acima.

\subsubsection{A identificação do condutor - CNH}

Atualmente os condutores de veículos automotores no Brasil são identificados pela CNH - Carteira Nacional de Habilitação. O atual modelo, instituído em 2006, pode ser visto na imagem da Figura 3-3.

Segundo Parodi (2010), a CNH:

"[...] é provavelmente o melhor documento de identificação disponível hoje no Brasil. Isso por algumas razões: É um documento com prazo de validade definido, portanto a foto sempre é relativamente recente. É um documento unificado, portanto igual em seu formato e modelo em todos os estados do Brasil, e com numeração única; É um documento de excelente qualidade de um ponto e vista da segurança, com numerosas características de segurança, de difícil reprodução e que usa materiais e recursos avançados e modernos; É um documento completo pois reporta, num mesmo suporte, numero do RG, numero da habilitação, numero do CPF, filiação, nascimento etc.; poderia ser ainda melhorado com a indicação de alguns dados a mais e a inclusão da digital (identificação por datiloscopia)". 


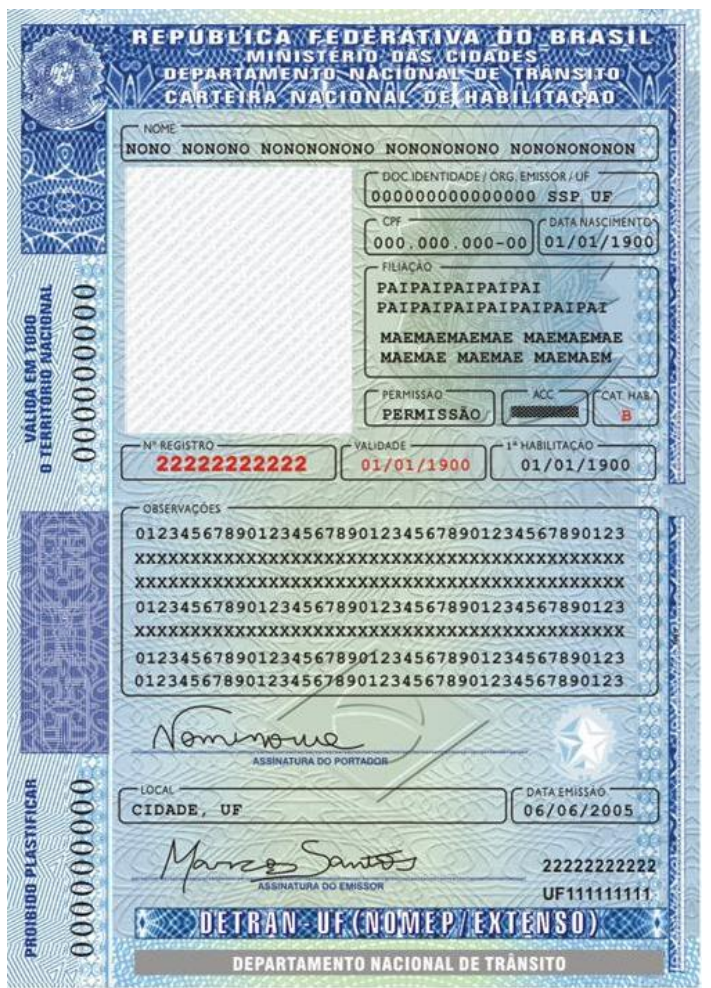

Figura 3-3 - A Carteira Nacional de Habilitação - CNH (DETRAN, 2009).

O fato relevante a este trabalho, é que a atual $\mathrm{CNH}$ reúne em um único documento as informações de outros dois documentos igualmente importantes no Brasil, o RG - Registro Geral, e o CPF - Cadastro Nacional de Pessoas Físicas. Isso significa que, embora não tenham sido encontrados documentos que confirmem essa afirmação, o DETRAN mantém uma base de dados que correlacionam todos os números de identificação destes documentos. E assim sendo, é possível realizar a consulta sobre todos os dados de um condutor habilitado conhecendo-se apenas o seu número de CPF.

Em função desta possibilidade de se correlacionar os documentos, abre-se a oportunidade de empregar-se a estrutura nacional de certificação do e-CPF - Cadastro de Pessoa Física eletrônico, como módulo de criptografia com cartão inteligente do projeto hora proposto. Não havendo por isso a necessidade de se recriar a estrutura de certificação.

Durante o período de pesquisa deste trabalho acompanhou-se de perto uma iniciativa do governo Brasileiro para a implantação do RIC - Registro de Identidade Civil. Trata-se de um cartão inteligente, semelhante ao utilizado na estrutura do e-CPF, que substituirá o atual 
documento oficial de identificação chamado de RG. Contudo até o encerramento deste trabalho esta iniciativa não havia sido colocada em prática o que inviabilizou a sua adoção. Mas, em se tratando de um cartão inteligente convencional o RIIVT poderá ser facilmente adaptado à sua utilização.

\subsection{O modelo de certificação proposto}

Uma vez compreendida a estrutura de certificação brasileira, pode-se analisar a estrutura de criptografia proposta para este projeto. O processo tem inicio com o fabricantes dos RIIVT solicitando aos AC's certificados de distribuição que os autorizam a emitirem certificados de equipamento para os seus produtos. Os fabricantes se encarregam de instalar e controlar os certificados emitidos e comunicar suas chaves públicas para a AC hierarquicamente superior. Desta forma os RIIVT são identificados de maneira inequívoca dentre todos os produtos de um fabricante e de todos os demais fabricantes do país. Desta forma além de garantir a identidade de cada unidade RIIVT também é possível evitar a sonegação de impostos, pois cada certificado emitido significa uma unidade produzida.

Na outra extremidade do processo estão os diferentes grupos de usuários, condutores, técnicos e autoridades policiais. Todos têm acesso ao RIIVT através de cartões inteligentes do tipo e-CPF A3 para pessoas físicas ou e-CNPJ A3 para pessoas jurídicas. No caso das autoridades policiais o acesso se faz através de um cartão e-CNPJ que identifique a corporação, da mesma maneira os técnicos que executem manutenção no equipamento. $\mathrm{O}$ RIIVT terá a capacidade de armazenar os últimos acessos de cada grupo ao equipamento, ou seja, o ultimo técnico a ter executado uma manutenção ou o último policial a ter feito uma fiscalização. O equipamento registrará também o dia e hora em que essa atividade foi realizada. 
O RIIVT estará permanentemente monitorando as informações de deslocamento, mas só realiza o registro das mesmas após a inserção de um cartão de condutor.

$\mathrm{O}$ arquivo resultado do registro das informações de deslocamento são criptografados e assinados com a chave pública do condutor ao seu fechamento que é realizado a intervalos fixos de tempo. A estrutura de certificação descrita pode ser observada na Figura 3-4.

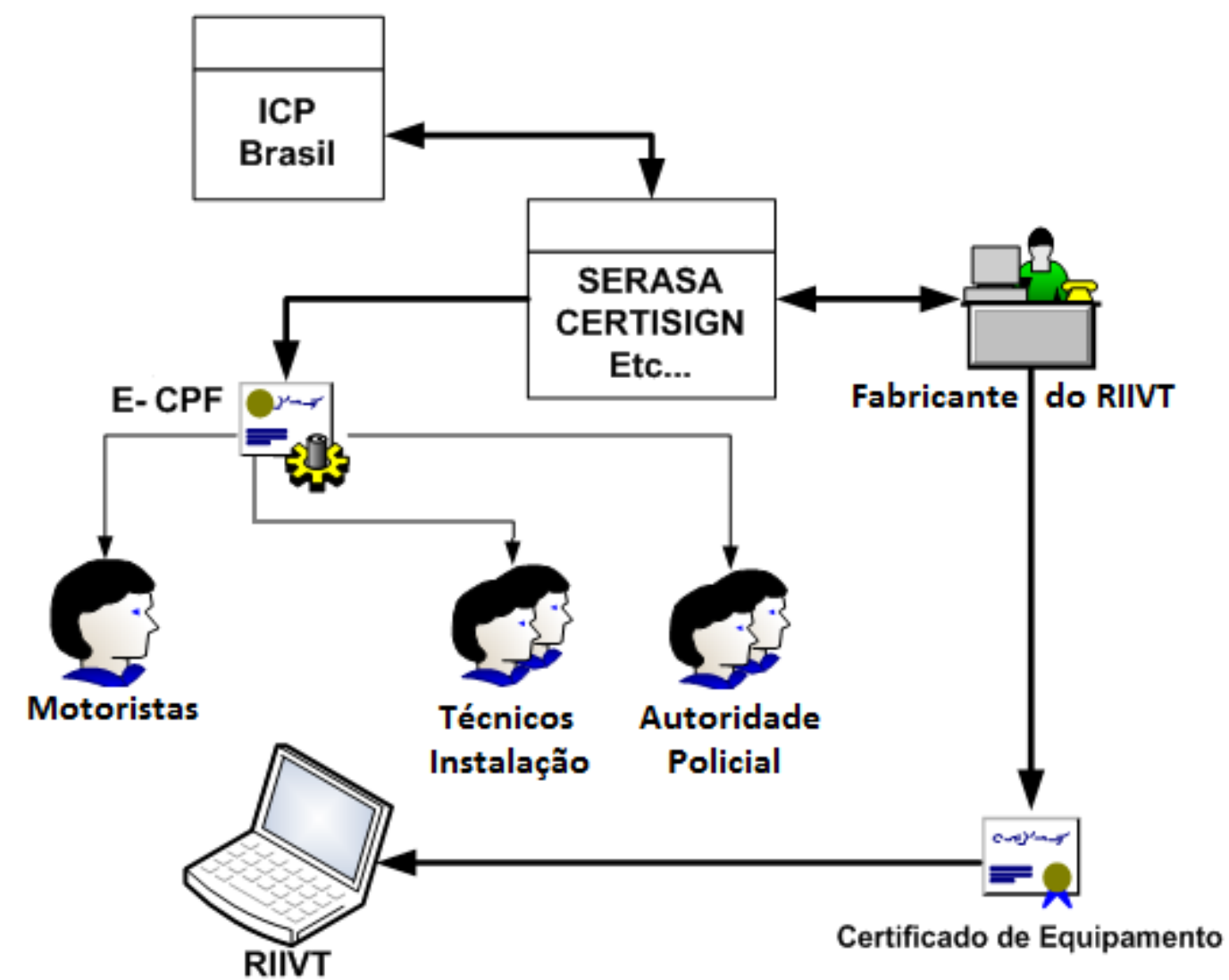

Figura 3-4 - Estrutura de certificação proposta.

O inconveniente do modelo proposto é que não é possível a realização de testes de envolvimento toda a cadeia de autoridades de certificação do processo proposto. Desta forma a validação completa do modelo proposto fica prejudicada. Entretanto, as tecnologias envolvidas são de domínio público e testadas em situações semelhantes, de forma que a impossibilidade de realização de testes não fragiliza o modelo proposto.

Foi possível realizar testes apenas na última etapa do processo em que os arquivos de registro de condução podem ser assinados e criptografados. 


\subsection{O subsistema de comunicação sem fios}

A finalidade do subsistema de comunicação sem fios é o de estabelecer um canal bidirecional de comunicação sem fios entre o sistema embarcado no veículo de carga e um dispositivo de fiscalização. O subsistema precisa comportar a conexão em movimento, tanto do veículo de carga quanto do dispositivo de fiscalização.

Para atingir plenamente o objetivo proposto acima é necessário conhecer detalhadamente as diversas tecnologias de conexão sem fios disponíveis no mercado e as implicações de sua adoção.

Voltando à Tabela 2-3, observamos que a tecnologia 802.11 não é normatizada para funcionar com o veículo se deslocando em altas velocidades, a tecnologia celular tem o custo de serviço de trafego de dados muito elevado e a WiMax ainda não foi regulamentada para uso no Brasil.

Por todas as características expostas acima, em especial em função de sua adoção mundial, a tecnologia WAVE é a solução ideal para o projeto hora proposto. Embora o WAVE esteja em vias de se tornar uma norma, ele ainda não o é, e por este motivo não existem produtos no mercado que atendam a esta especificação. Este fato inviabiliza a realização de testes com essa tecnologia. Mas como o WAVE é definido em consonância com os demais projetos IEEE 802, a implementação de algoritmos para troca de mensagens usando protocolos de comunicação das camadas superiores da arquitetura garante o funcionamento em qualquer interface de comunicação utilizada, desde que seja compatível com a especificação IEEE 802 e TCP/IP. 


\subsubsection{A interface de rede}

Diante do exposto no tópico anterior o adaptador de rede escolhido para equipar o projeto do RIIVT deve atender plenamente àquelas expectativas. Por isso o modelo selecionado foi baseado em um chip da Realtek modelo RTL8187B que, segundo o fabricante, atende as revisões IEEE $802.11 \mathrm{~b}$ e $802.11 \mathrm{~g}$. Ele suporta as modulações DBPSK, DQPSK e CCK no modo 802.11b, e BPSK, QPSK, 16QAM e 64QAM no modo 802.11g. Elas são automaticamente selecionadas em função da distância entre o ponto de acesso e adaptador de rede, e também em função das condições de propagação de sinais no local.

Sua conexão ao sistema computacional é feito também através de barramento USB, o que permite manter o adaptador de rede fora do veículo para melhorar as condições de recepção de sinais. A Figura 3-5 mostra o adaptador de rede selecionado para a aplicação.

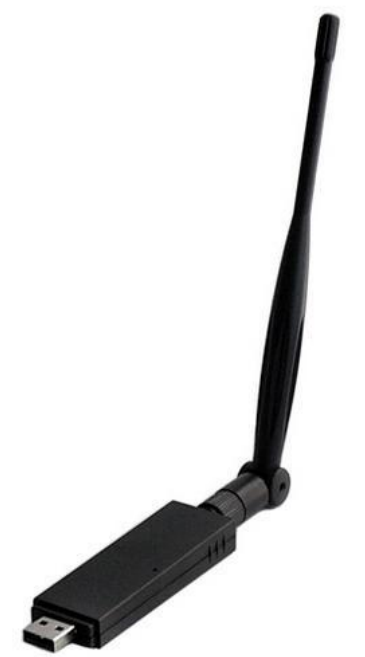

Figura 3-5 - Adaptador de rede sem fios Realtek 8187B.

No projeto proposto, este adaptador de rede é responsável por monitorar constantemente a presença de sinais emitidos por um ponto de acesso. Os pontos de acesso são dispositivos concentradores que permitem a conexão entre diversos adaptadores de rede dentro de sua área de cobertura. Eles estão constantemente anunciando a sua presença através de pacotes especiais de dados chamados de beacom frames. Quando a interface de rede instalada no veículo encontra um ponto de acesso ele imediatamente inicia um processo de 
chamado associação, onde é negociada uma conexão de rede criptografada. Após este processo o adaptador de rede do veículo poderá trocar pacotes de informação com outros dispositivos conectados ao mesmo ponto de acesso, ou, com qualquer outro computador do mundo se este ponto de acesso estiver ligado à Internet.

O equipamento de fiscalização está conectado ao ponto de acesso, monitorando as conexões realizadas. Uma vez que uma nova conexão tenha sido estabelecida o equipamento de fiscalização solicita as informações de condução do veículo e encerra a sessão. Tudo isto realizado em apenas alguns segundos, sem a abordagem do veículo e em qualquer condição climática. A Figura 3-6 exibe um diagrama do sistema de comunicação proposto.

O agente policial responsável pela operação do equipamento pode estar conectado a Internet via uma conexão GSM, que lhe permitirá acesso à base de dados do DETRAN para consulta de habilitações ou registro de infrações realizadas. Este equipamento pode estar instalado também na própria viatura policial, permitindo que a fiscalização possa ser feita em movimento, respeitando-se a velocidade relativa dos veículos, de $110 \mathrm{~km} / \mathrm{h}$ determinado pela norma 802.11p. Esse detalhe é especialmente importante quando os veículos trafegam em direções opostas.

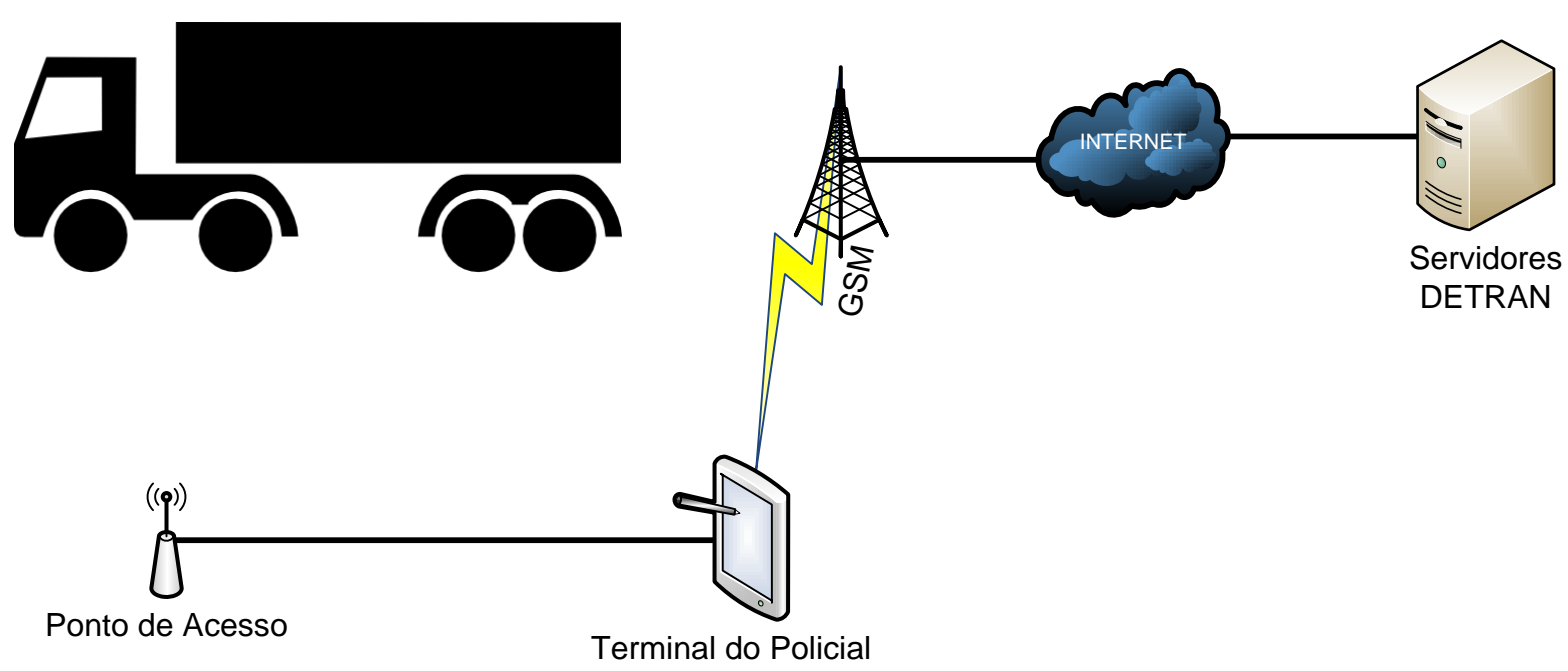

Figura 3-6 - Proposta do sistema de fiscalização sem fios. 


\subsection{O sistema central de processamento}

O sistema central de processamento consiste na plataforma computacional utilizada para realizar a aquisição dos sinais do GPS, processá-los, armazenando em seguida os resultados em dispositivo adequado e assinando os arquivos com a chave do condutor. Além disso, deve monitorar a tentativa de conexão através de um sistema de comunicação sem fios, autenticando a conexão e o equipamento interlocutor, transmitindo-lhe as informações sobre as últimas horas de condução deste veículo além da identificação do condutor.

Note-se que todos os subsistemas concebidos neste projeto interligam-se ao sistema de processamento central utilizando o barramento USB. Essa medida foi premeditada, pois se trata de um padrão mundial aberto para a interconexão de periféricos que permite toda uma sorte de combinações para o sistema.

A Figura 3-7 exibe a concepção completa do sistema proposto através de um diagrama de blocos.

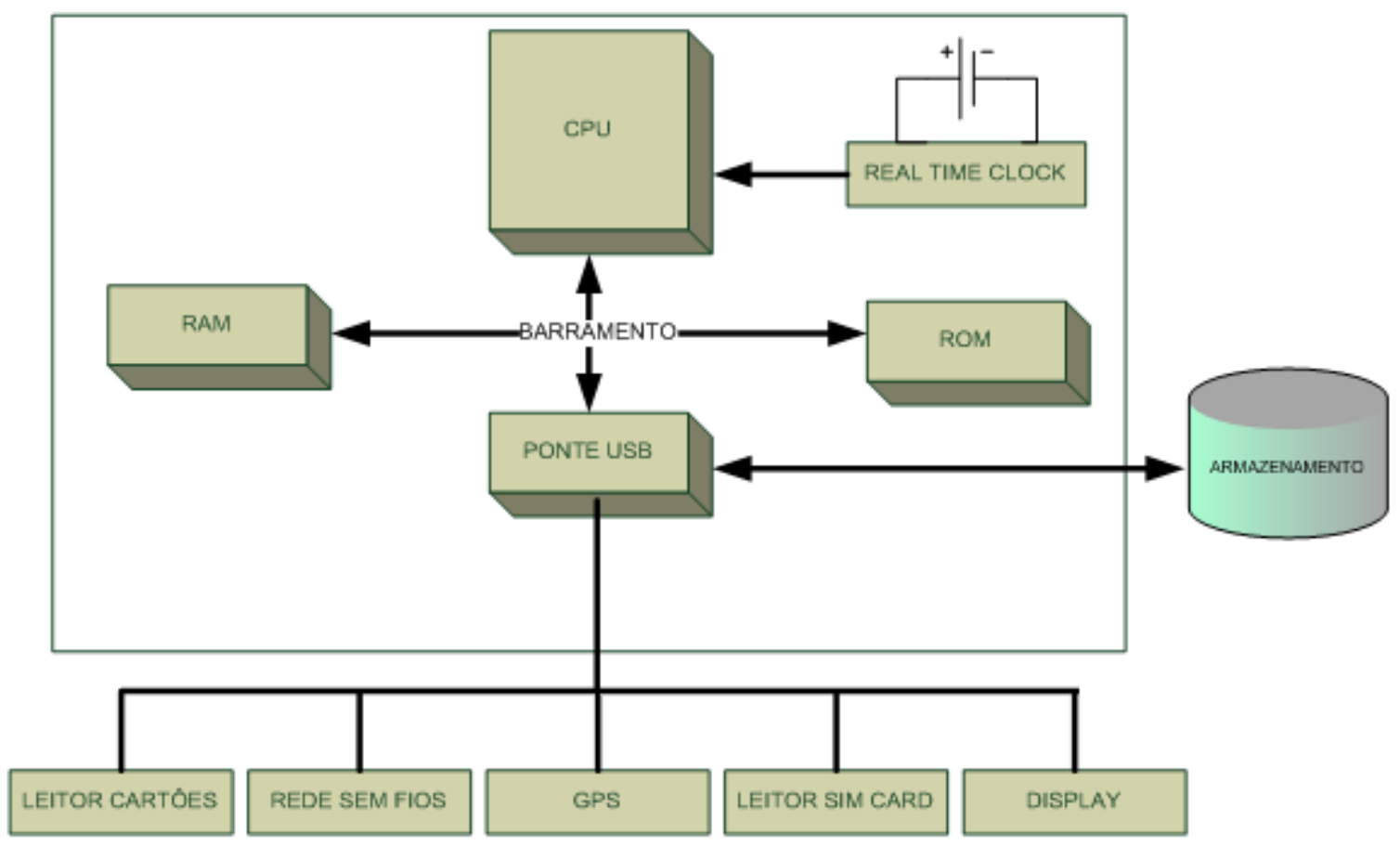

Figura 3-7 - Concepção do sistema central de processamento. 
A base do sistema é um computador convencional baseado na arquitetura clássica RAM, ROM e I/O. A CPU deve ser capaz de executar um sistema operacional multitarefa de 32 bits como o Linux ou Windows Embedded, para manter a compatibilidade com as bibliotecas criptográficas do GNUPG. Isso reduz o universo de arquiteturas disponíveis à x86 e ARM.

Um relógio de tempo real é necessário para manter a data do sistema atualizada mesmo na ausência do sistema GPS. Os subsistemas GPS, de aquisição e de rede sem fios já foram descritos pormenorizadamente nos itens anteriores.

Já o leitor de SIM-CARD e o leitor de cartão inteligente são baseados num chip conversor entre o protocolo de comunicação dos cartões e o barramento USB. O SIM-CARD é um cartão inteligente completo, sua diferença fica apenas por suas dimensões físicas que são bem menores quando comparadas com um cartão inteligente convencional. Ele é semelhante aos SIM-CARD's dos telefones celulares e sua função é de armazenar de forma segura as chaves e os certificados criptográficos do equipamento. Eles são gerados pelo fabricante e lacrados no interior do equipamento.

Já o leitor de cartão inteligente do condutor deve ser acessível pelo mesmo, a fim de inserir e retirar o seu cartão de identificação com facilidade.

O sistema de armazenamento deve ser capaz de armazenar as informações de deslocamento por um período superior a uma semana. O seu tamanho em bytes será determinado durante o desenvolvimento do algoritmo principal do sistema.

O display é facultativo, uma vez que o condutor não depende de informações disponibilizadas pelo equipamento para realizar a sua tarefa e a fiscalização é realizada sem o acesso físico ao equipamento. 
Como o sistema proposto congrega uma quantidade de instrumentos e subsistemas bastante diversos, ele pode ser utilizado para mais uma função, como por exemplo, um sistema de navegação por GPS e, ou ainda, um roteirizador de entregas, neste caso a adoção de um display de grande resolução com tela sensível ao toque pode ser muito útil.

Observa-se então que a plataforma computacional sob o qual o projeto proposto será executado pode servir como ponto de partida para a oferta de outros serviços que poderiam colaborar com a viabilidade financeira do mesmo.

Seguindo os critérios explicitados acima a placa de processamento adotada foi a Beaglebord. Trata-se de um projeto open source de um computador completo, com o desempenho de um laptop, dedicado ao desenvolvimento de sistemas embarcados. Suas dimensões são compactas, 3 x 3 polegadas, baixo consumo de energia e baixa dissipação de calor, necessitando apenas de uma fonte de alimentação simples de 5 volts. A Figura 3-8 exibe as principais características da Beagleboard elencadas pelo fabricante.

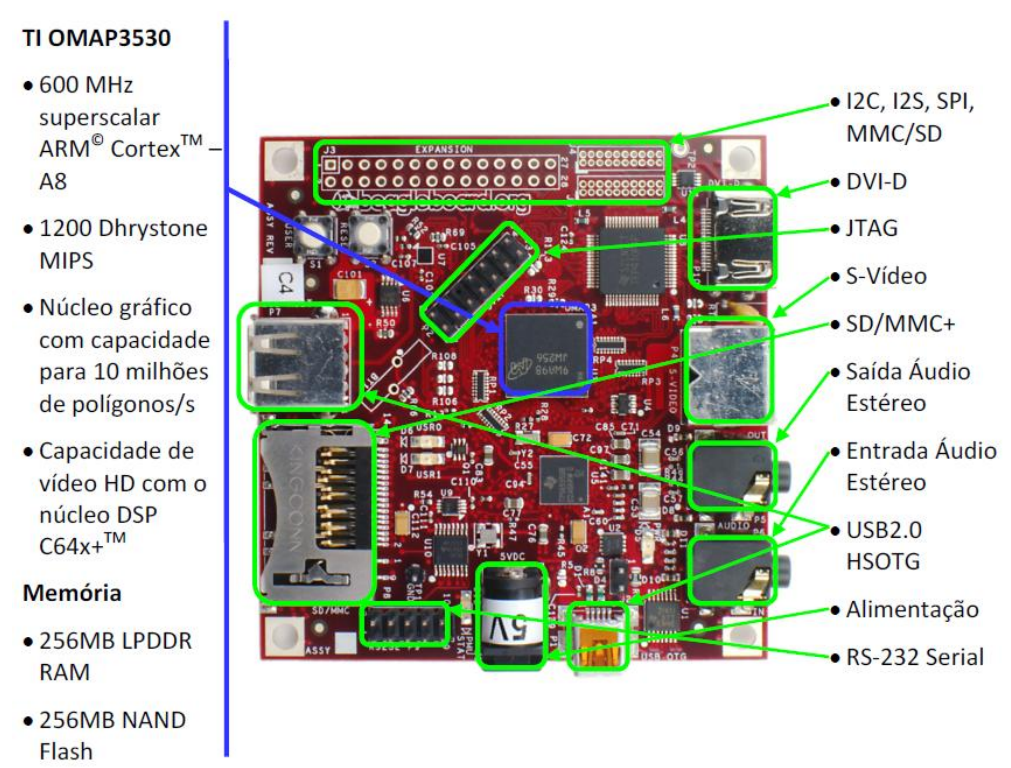

Figura 3-8 - Características técnicas da Beagleboard.

O processador OMPA3530, fabricado pela Texas Instruments, foi desenvolvido para aparelhos de telefone celular do tipo smart phone, sendo dotado de grande capacidade de processamento e baixo consumo. Seu núcleo é baseado no ARM11 que o torna compatível 
com as bibliotecas de criptografia discutidas anteriormente. O sistema ainda dispõe de 256 MB de memória RAM DDR parra execução dos programas e 256 MB de memória flash para armazenamento do sistema operacional. As informações de deslocamento ficarão armazenadas em um cartão de memória SD de 4 GB de capacidade.

\subsubsection{Sistema operacional}

A Beagleboard é compatível com diversos sistemas operacionais disponíveis no mercado. Contudo, para manter o custo de desenvolvimento baixo, optou-se pela utilização do sistema operacional Linux. A distribuição adotada foi a Ubuntu, versão 10.04 de codinome lucid, e baseada na versão 2.6.34 do kernel. Foram instalados os pacotes mínimos da distribuição, que ocuparam aproximadamente 300 MB do cartão de memória SD. Não foram instalados componentes de interface gráfica por não serem necessários. Todas as configurações e programações foram realizadas através da interface serial conectada a um computador pessoal.

Essa distribuição oferece suporte nativo a todos os dispositivos da Beaglebord, incluindo o receptor de GPS, o leitor de cartões e o adaptador de rede sem fios, simplificando assim o desenvolvimento do RIIVT.

\subsubsection{O acesso ao receptor de GPS}

O receptor de sinais GPS, quando conectado ao sistema, é mapeado como um dispositivo de comunicação serial em /dev/ttyUSBO. Se este dispositivo for aberto para leitura por um programa, ele ficará bloqueado, e não será acessível por nenhum outro. Isso impede que múltiplos programas possam acessar, ao mesmo tempo, as informações do receptor de GPS.

Para solucionar este problema de concorrência adotou-se uma solução baseada no software GPSd. Ele é um daemon do sistema operacional, um software que é executado em 
segundo plano pelo Linux. Sua função é conectar-se ao receptor de GPS e disponibilizar as suas informações através de uma conexão de rede TCP na porta 2947. Essa solução permite que múltiplos programas que estejam em execução possam acessar os dados do GPS, não só localmente, mas também remotamente através de conexões de rede.

\subsubsection{O relógio do sistema}

Para a manutenção de data e hora no sistema a Beagleboard é equipada com um RTC - Real Time Clock, relógio de tempo real que se mantém em funcionamento através de uma bateria de 3 volts. Essa bateria não é fornecida pelo fabricante da beagleboard e foi adicionada para a realização dos testes. O RTC da beagleboard, como o de qualquer outro sistema computacional, não é dotado de grande precisão, apresentando desvios de alguns minutos após alguns dias de funcionamento.

A fim de minorar este infortúnio adotou-se a referência de tempo disponível no sistema GPS, atualizando-se o relógio do sistema tão logo os sinais GPS estejam disponíveis. Essa tarefa foi realizada através do daemon NTP - Network Time Protocol. Este software obtêm a base de tempo UTC - Universal Time Coordinated, do GPS solicitando-a ao daemon GPSd, transforma-a para o horário local, que no Brasil é GMT -3, e atualiza o relógio do sistema. Este software monitora ainda a imprecisão do RTC e aplica a ele um coeficiente de correção visando diminuir o seu erro no futuro.

A imagem da Figura 3-9 apresenta o aspecto final do protótipo do RIIVT, com todos os periféricos conectados, e prontos para a realização dos testes. Não aparece na imagem o regulador redutor da tensão de 12 volts disponível no veículo para os 5 volts necessários para o funcionamento da beagleboard. No centro do gabinete é possível ver também o leitor de smartcard, e o hub USB do lado esquerdo do gabinete. 


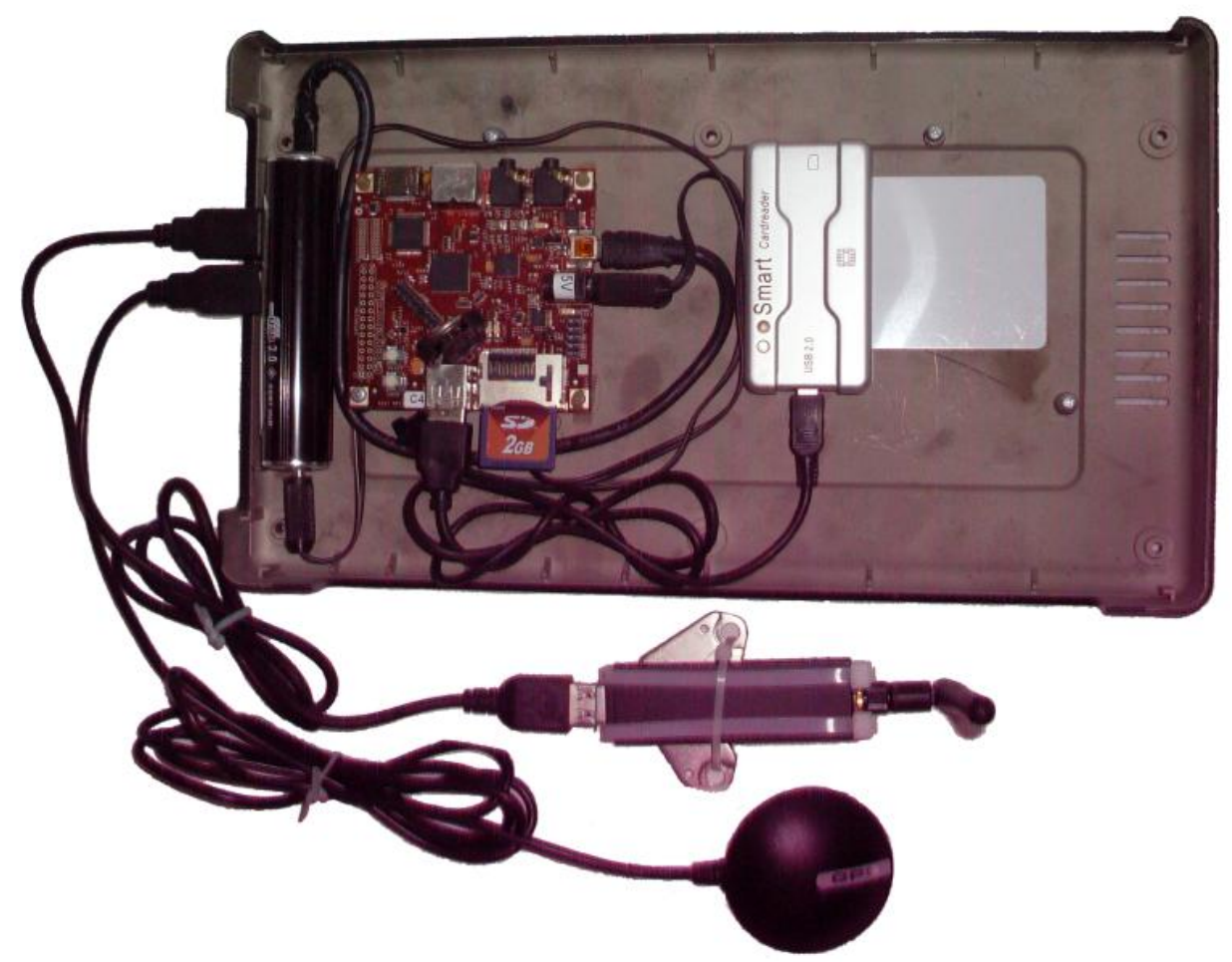

Figura 3-9 - Visão do protótipo do RIIVT.

\subsection{O fiscalizador}

O sistema de fiscalização foi concebido para ser o mais simples possível e independente de plataformas computacionais dedicadas. A finalidade dessa premissa é a de permitir que ele seja executado em computadores pessoais, laptops ou ainda aparelhos de telefone celular. Basta que sejam capazes de se comunicar utilizando a pilha de protocolos TCP/IP, através de uma conexão de rede sem fios IEEE802.11 ou ainda uma conexão cabeada no padrão IEEE802.3.

O ponto central do sistema de fiscalização é o ponto de acesso da rede sem fios, conhecido também como access point ou roteador wireless. Sua função é a de gerenciar de maneira centralizada a comunicação entre adaptadores de rede que estejam dentro de sua área de cobertura. Qualquer ponto de acesso disponível no mercado que atenda integralmente a especificação IEEE802.11 pode ser utilizado, não se tratando portanto de uma especificação crítica. 
O detalhe que pode diferenciar o ponto de acesso de um fabricante dos demais é o número de adaptadores ativos que ele é capaz de gerenciar. Esse número é dependente do processador com que é equipado e da quantidade de memória RAM disponível, pois cada conexão de rede ativa consome-lhe um determinado tempo de processamento e respectiva quantidade de memória.

Considerando-se as condições típicas de trafego em rodovias, num raio de cobertura de 100 metros, não é de se esperar mais de dez conexões ativas simultâneas. Mesmo sob condições de engarrafamento, é pouco provável que aconteça um maior número de conexões, pois os veículos não adentram a área de cobertura simultaneamente, e as conexões se encerram tão logo as informações necessárias sejam transmitidas.

Para a realização dos testes de campo foi empregado um ponto de acesso da marca Kodama, modelo KOD-770 que é direcionado ao uso profissional. Suas principais características são: Atendimento às normas IEEE 802.11b, 802.11g e 802.3; 16 Mb de memória RAM; potência de transmissão de $18 \mathrm{dBm}$; 5 portas para rede cabeada 802.3; e capacidade para 32 conexões simultâneas. A figura Figura 3-10 apresenta o ponto de acesso Kodama KOD-770.

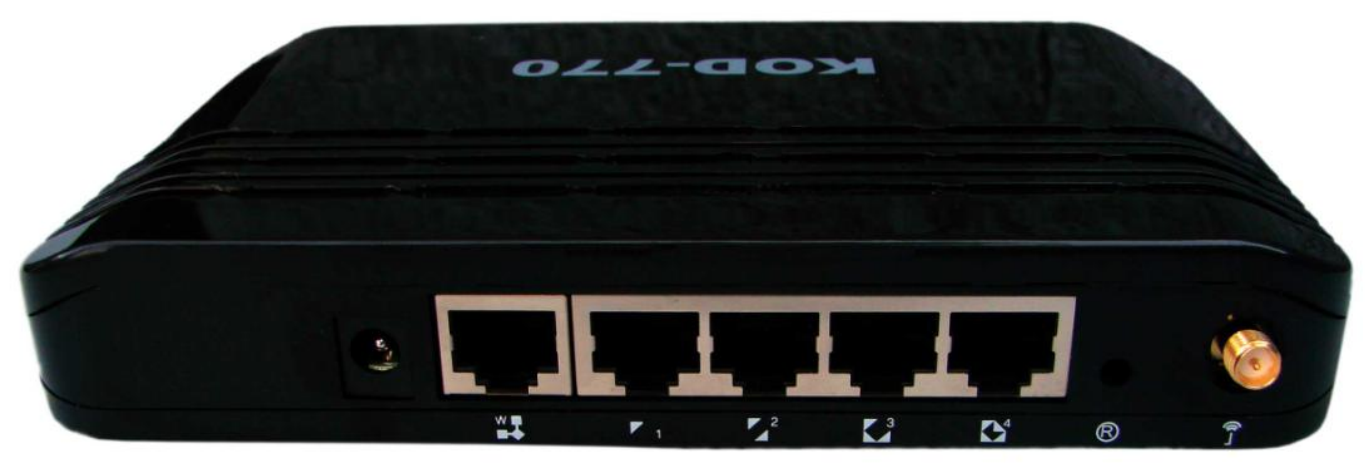

Figura 3-10 - Ponto de acesso KOD-770. 
Para diminuir o tempo de desenvolvimento, o software do fiscalizador foi desenvolvido em linguagem de programação Labview versão 2009 da National Instruments. Após o desenvolvimento o seu funcionamento foi testado nos sistemas operacionais Windows 7, Linux Ubuntu 10.04 e Windows Embedded 6, tendo funcionado adequadamente em todos. O seu funcionamento é descrito no diagrama de blocos da Figura 3-11.

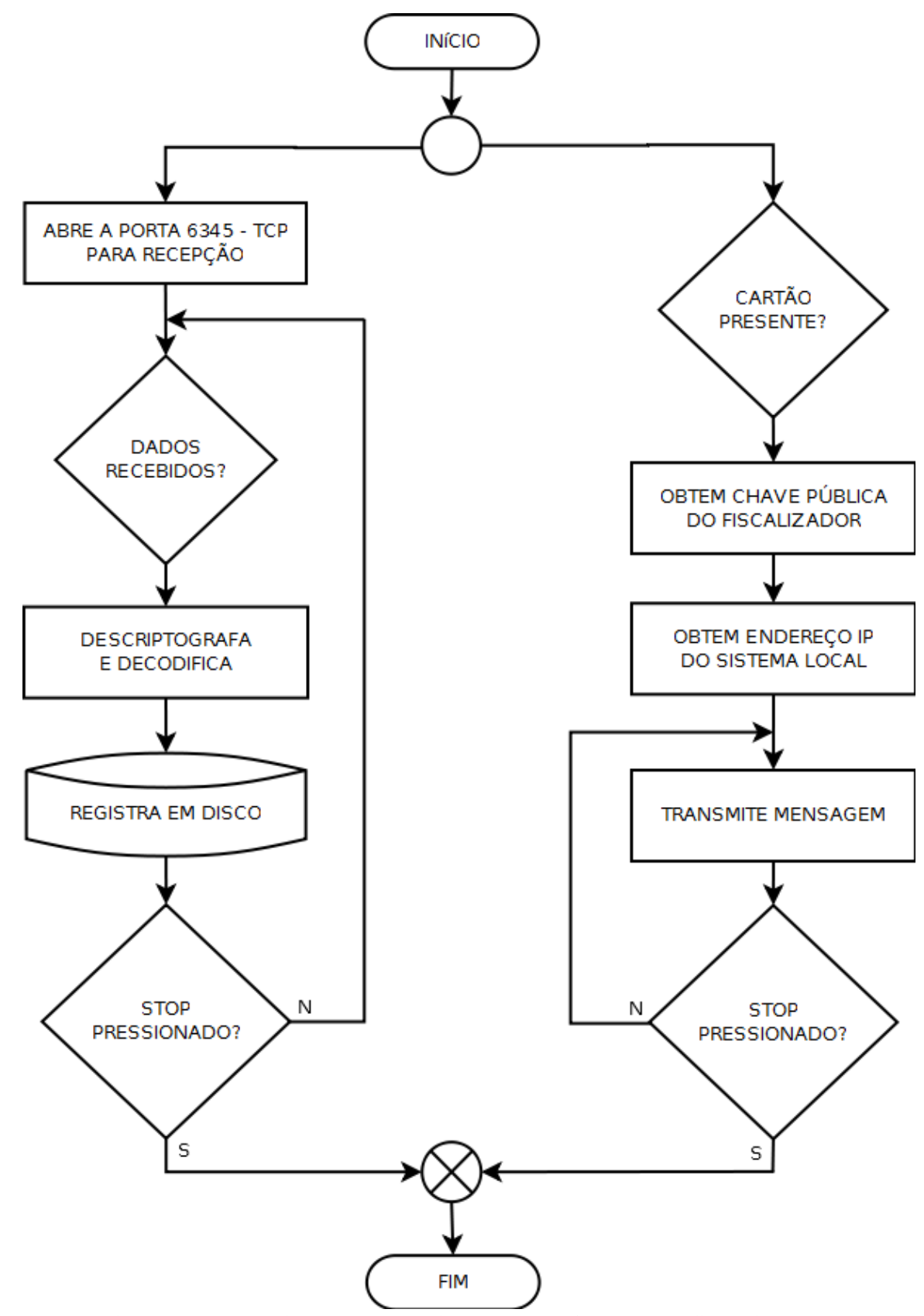

Figura 3-11 - Diagrama de blocos do software do fiscalizador.

Uma vez iniciada sua execução o programa procura pela presença de cartões inteligentes conectados ao sistema, a fim de identificar o agente da lei que está realizando a 
fiscalização. Localizado o cartão, o programa obtém a chave pública do agente da lei, seu nome e número do seu CPF. Em seguida ele obtém o endereço IP do sistema em que está sendo executado, agrupa esta informação com as obtidas do cartão inteligente, transformandoas em uma mensagem. Essa mensagem contendo as informações do agente da lei e do endereço IP do fiscalizador é constantemente transmitida pela interface sem fios. Ela é direcionada para o endereço IP 255.255.255.255 que é chamado endereço de broadcast, de forma que todos os adaptadores de rede dentro da área de cobertura do ponto de acesso estão constantemente recebendo estas informações. A mensagem de broadcast é retransmitida a cada 100ms pela porta 61556 com destino à porta 61557 dos adaptadores de rede instalados nos veículos.

O protocolo utilizado nessa comunicação é o UDP - User Datagram Protocol, disponível na camada de transporte do modelo TCP/IP. Sua principal diferença com relação ao protocolo TCP é o fato de não ser orientado à conexão, ou seja, ele não depende de uma resposta de seu equipamento interlocutor para encerrar o seu ciclo de transmissão. Isso é especialmente útil por dois motivos. $\mathrm{O}$ fato de a mensagem ser transmitida a maior parte do tempo sem que exista nenhum veículo para recebê-la e respondê-la faria com que ocorresse erro por falta de resposta, que é inerente ao protocolo TCP. E os pacotes de dados TCP, por carregarem mais informações necessárias ao estabelecimento da conexão, precisam de mais tempo para ser transmitidos, diminuindo assim o desempenho global do sistema.

O principal inconveniente do protocolo UDP é que seus mecanismos de tratamento de erro são pouco complexos de modo que o programa não é capaz de detectar automaticamente se o adaptador de rede do veículo recebeu corretamente a mensagem. Mas esse inconveniente é minorado uma vez que a mensagem é retransmitida novamente em 100ms.

Além disso, ao iniciar a transmissão constante de mensagens o programa de fiscalização abre também a porta 6345, para a recepção de mensagens TCP provenientes dos 
veículos. Estes ao adentrarem a área de cobertura do ponto de acesso receberão a mensagem do fiscalizador no qual consta o endereço IP do mesmo, e responderão com as suas informações de tempo de condução. Note-se que para a resposta foi utilizado o protocolo TCP, a fim de que o veículo receba de volta a confirmação de que a sua resposta foi entregue ao fiscalizador e possa encerrar a sessão, liberando os recursos da rede.

No programa de testes do fiscalizador as mensagens são recebidas, descriptografadas com a chave privada disponível no cartão inteligente, e armazenadas em disco para conferência posterior. Numa versão final o software realiza, imediatamente após a descriptografia, a verificação dos tempos de condução para a emissão de automática de infração. Poderia também, utilizando de uma conexão à Internet, verificar a documentação do condutor do veículo, determinando se contra ele exista alguma restrição que exija a sua abordagem imediata. A Figura 3-12 exibe a interface do programa do fiscalizador. Observe que o programa exibe colunas extras utilizadas durante a realização dos testes de campo e que não são utilizadas na proposta básica do sistema.

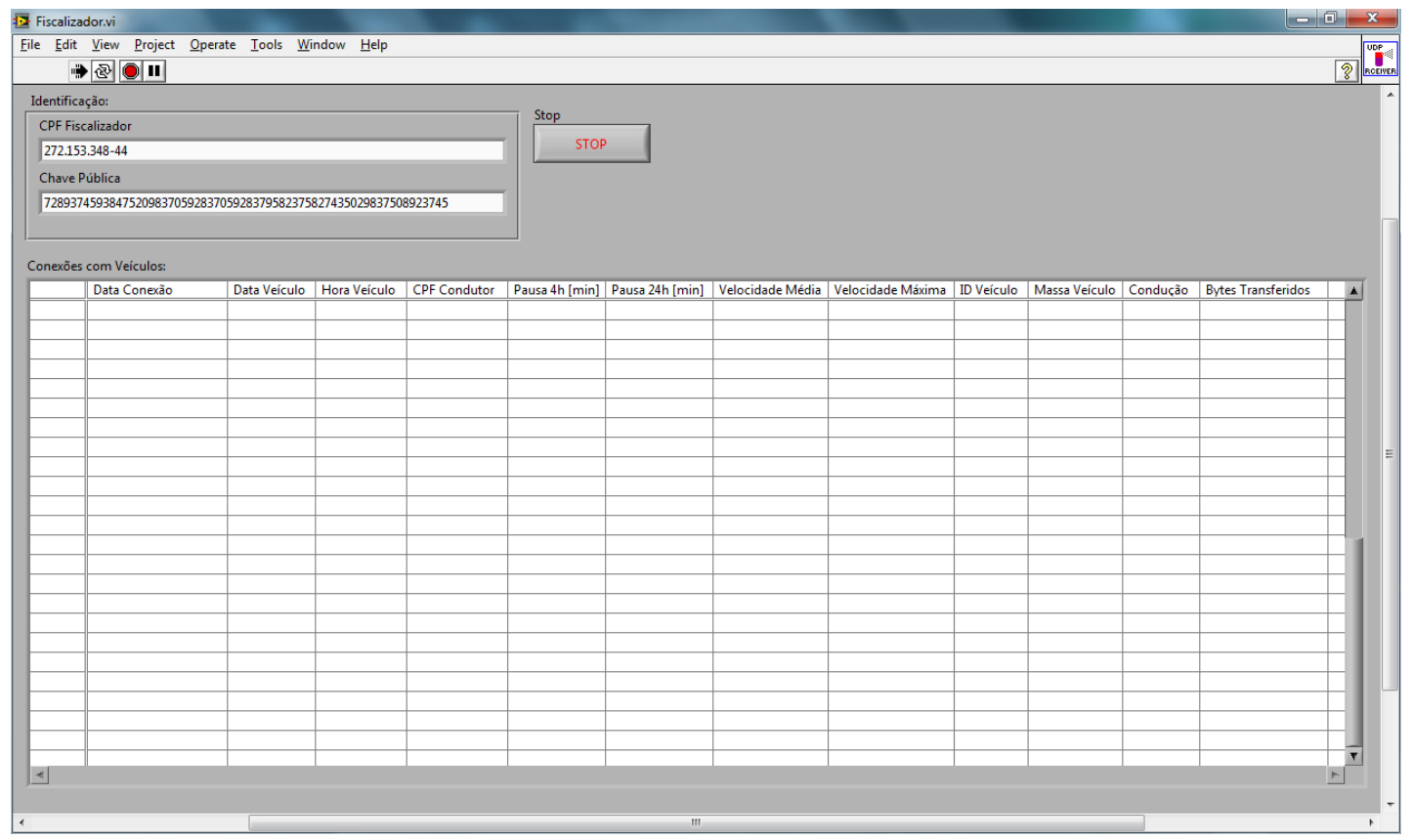

Figura 3-12 - Interface do programa do fiscalizador 


\subsection{Os programas do RIIVT}

O software residente no registrador é bem mais complexo que o do fiscalizador e é dividido em três diferentes programas. Todos os programas foram desenvolvidos em linguagem de programação Python, e o banco de dados utilizado no armazenamento de informações é o SQLite3.

\subsubsection{O programa de comunicação}

Depois de estabelecidas as condições descritas no item 3.4 relativas ao sistema operacional, o adaptador de rede sem fios é colocado em modo de busca. Ele vasculha os canais de rádio à procura de pacotes especiais de dados transmitidos pelos pontos de acesso chamados de beacom frames. Eles carregam um campo que identifica o ponto de acesso, chamado de ESSID. A Figura 3-13 exibe o diagrama de blocos deste sistema.

Quando o programa de comunicação recebe um beacom frame contendo o ESSID Road-Infra, ele inicia o processo de associação ao ponto de acesso. Após o estabelecimento da associação o programa será capaz de receber as mensagens provenientes do sistema de fiscalização. É imperativo que todos os pontos de acesso nesta proposta tenham sempre o mesmo ESSID, utilizado como referência pelo programa de comunicação do RIIVT.

Ao receber a mensagem de identificação proveniente do fiscalizador o RIIVT processa-a, obtendo o endereço IP e a porta de retorno, além das informações de identificação do agente da lei. Feito isso o RIIVT consulta o seu diretório de variáveis temporárias e obtêm as informações atualizadas do deslocamento do veículo e do condutor, assina-as utilizando a chave privada do condutor, disponível no cartão inteligente, criptografa-as com a chave pública recebida do fiscalizador, e a transmite como resposta. Ao receber a confirmação de que sua resposta foi recebida o software de comunicação registra em seu banco de dados o 
momento da fiscalização e o agente da lei que a executou, e volta ao seu estado de busca por beacom frames, iniciando assim um novo ciclo.

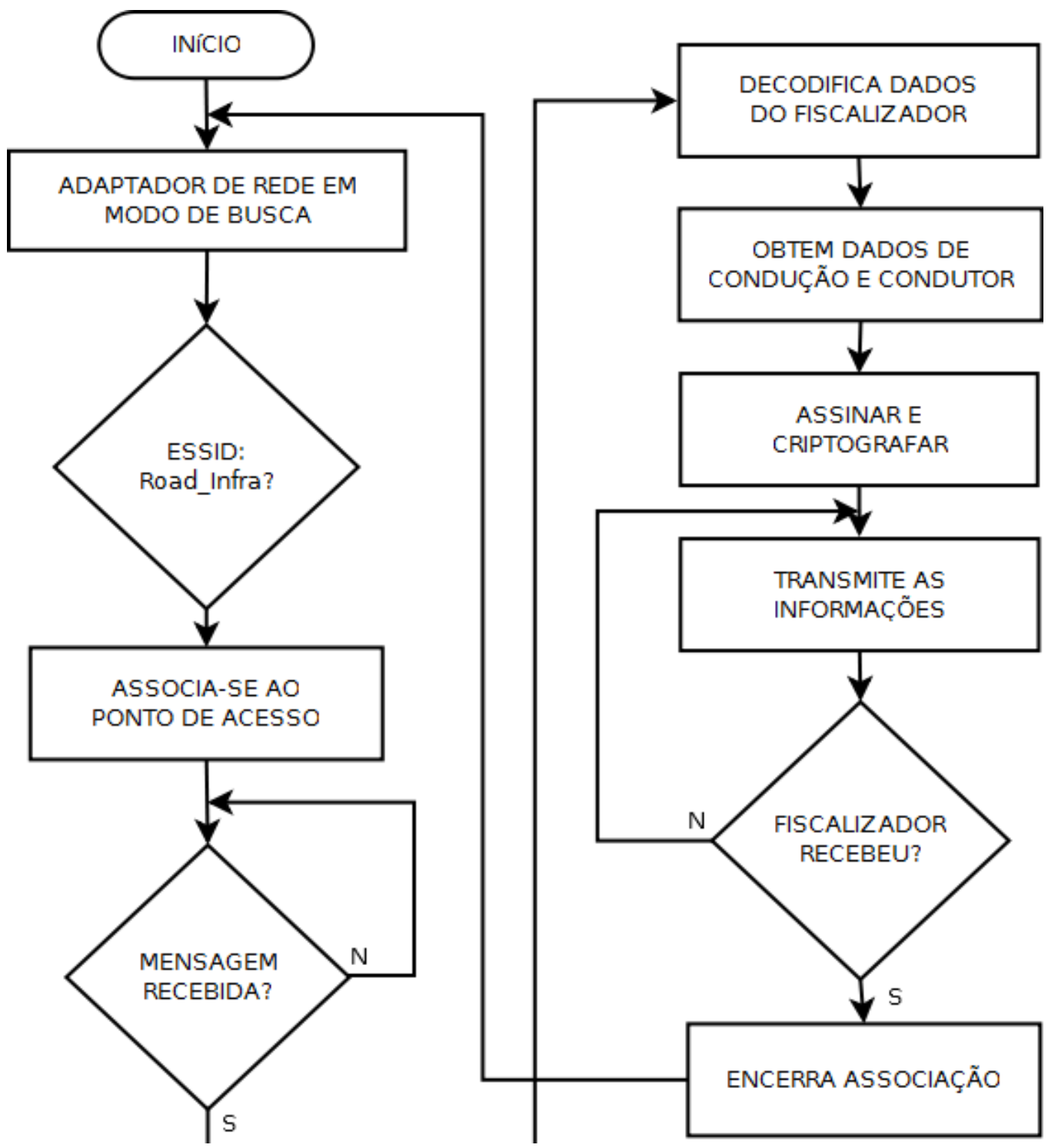

Figura 3-13 - Diagrama de blocos do programa de comunicação.

O processo de assinar os dados a serem transmitidos consiste apenas em transmitir um campo extra de informações que informe o valor hash dos dados. Uma vez que os dados estejam criptografados, utilizando-se a chave pública do agente da lei, somente ele, de posse do seu cartão inteligente, poderá descriptografá-la e visualizar o seu conteúdo. Mesmo que a mensagem seja interceptada por um receptor nas proximidades ela não terá nenhuma utilidade. 


\subsubsection{O programa de registro}

Este programa monitora os sinais provenientes do receptor de GPS disponibilizados pelo daemon GPSd. Uma vez por segundo ele consulta o GPSd através de uma conexão TCP local, obtendo as informações de latitude, longitude, velocidade no solo, data e hora; e armazena-as em uma matriz. Após 60 segundos estes dados são assinados digitalmente com a chave privada do condutor, disponível em seu cartão inteligente, sendo armazenado em seguida no banco de dados. Estes dados são registrados em intervalos de 60 segundos para minimizar o esforço computacional de registro no banco de dados. A Figura 3-14 exibe o diagrama de blocos do programa de registro.

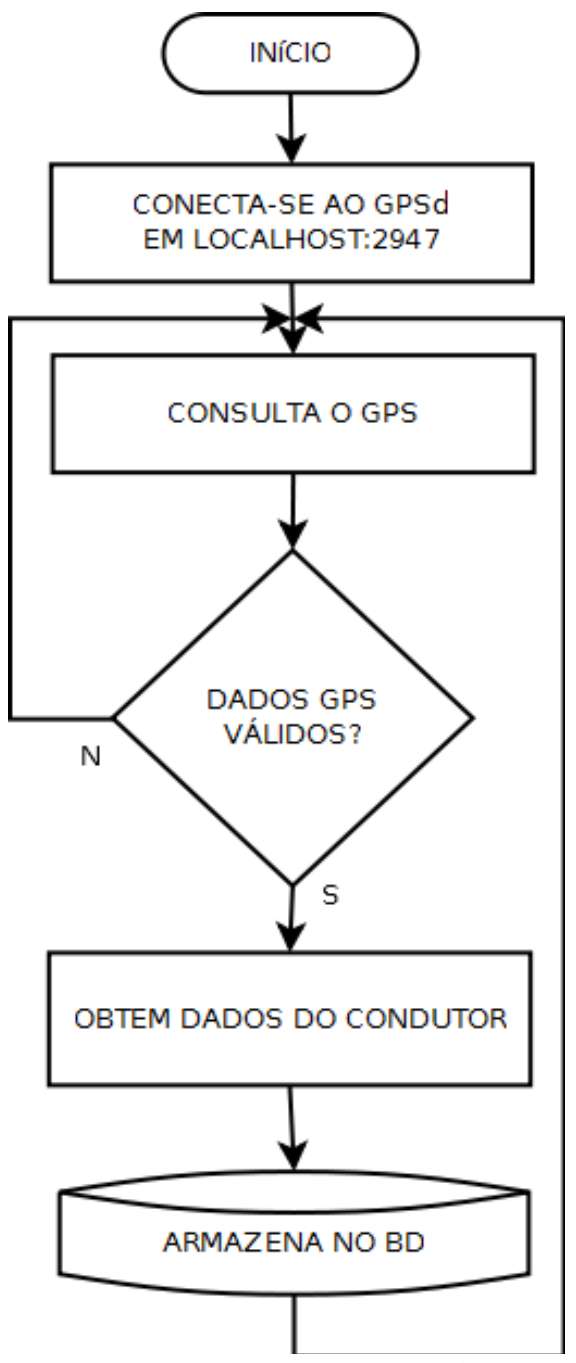

Figura 3-14 - Diagrama de blocos do software de registro 
Cada registro armazenado no banco de dados tem um tamanho médio de 88 bytes. Estima-se então que a plataforma computacional necessitará de um espaço de aproximadamente $8 \mathrm{MB}$ para cada 24 horas de registro. Com 1 GB de memória é possível portanto armazenar aproximadamente 125 dias de deslocamento, o que corresponde a mais de 4 meses. O banco de dados pode ainda ser configurado para exclusão automática de registros com data superior a um valor estabelecido.

\title{
3.7.3 O programa de análise
}

O último dos três programas que compõem o RIIVT é o programa de análise. Em intervalos de um minuto o programa de análise realiza um consulta SQL ao banco de dados obtendo deste as últimas 24 horas de registro do condutor. Estes dados de registro são analisados para se determinar o efetivo tempo de deslocamento do veículo neste período. Como já discutido anteriormente, o Brasil não tem uma legislação específica que normatize este cálculo. Por isso adotou-se o explicitado no projeto lei 2660/96, que não chegou a ser sancionado. Rodrigues (2010) assim explica este projeto:

\begin{abstract}
“[...] proíbe o motorista de caminhão e ônibus, trafegando em rodovias, dirigir mais de 4 horas ininterruptas, devendo descansar pelo menos 30 minutos de forma contínua ou descontinuada, ao longo das 4 horas dirigidas, exceto se iniciar o período de repouso. Poderá prolongar por até mais uma hora, desde que não comprometa a segurança viária, com objetivo de chegar a um ponto de parada adequado. O motorista fica obrigado, dentro do período de 24 horas a observar um intervalo ininterrupto de, no mínimo 10 horas de descanso."
\end{abstract}

Observe-se então que devem ser controladas duas variáveis, o tempo total de parada a cada 4 horas de deslocamento, contínuo ou não, e o tempo total de parada ininterrupta para cada 24 horas de deslocamento. Com fim de simplificação, essas variáveis serão chamadas doravante de PAUSA 24 e PAUSA 4.

O cálculo é realizado com a seguinte rotina. Obtêm-se a distância percorrida entre dois registros consecutivos e o intervalo de tempo entre eles. Caso o deslocamento tenha sido zero o intervalo de tempo obtido é somado até completar um minuto de deslocamento zero. Esse 
minuto de deslocamento zero é considerado como tempo parado ou tempo de descanso e é somado à variável PAUSA_24. Tomando-se o próximo registro, o processo é repetido de maneira semelhante. Caso o deslocamento não seja zero a variável PAUSA 24 recebe o valor zero. Uma vez que este intervalo de descanso não pode ser interrompido.

O cálculo da variável PAUSA_4 é realizado da mesma maneira, porém apenas sobre os registros das ultimas 5 horas. A análise das ultimas 5 horas deve-se ao projeto de lei supracitado que permite um prolongamento do percurso por mais uma hora para alcançar local adequado para o descanso. A Figura 3-15 exibe o fluxograma do programa de análise de deslocamento do RIIVT.

Os testes de funcionamento dos programas e dos demais subsistemas que compõem o RIIVT estão descritos no capítulo seguinte.

O conjunto dos três programas em execução no RIIVT atende plenamente a resolução do CONTRAN número 92 de 1999, apresentada no capítulo 2, que descreve os requisitos técnicos mínimos do RIIVT de uso obrigatório.

O RIIVT proposto registra a posição geográfica do veículo e o seu instante preciso, uma vez por segundo. Daí é possível determinar matematicamente a sua velocidade em todos os trechos, a distancia percorrida, tempo de operação e suas interrupções, data e hora do início e término da operação e identificação do condutor.

Apenas duas exigências não são atendidas da maneira prevista em lei. A identificação do veículo, que agora passa a ser realizada pelo sistema SINIAV, e a leitura dos valores registrados que precisa ser realizada com o auxílio da estrutura de rede do sistema proposto. A quantidade de informações extras disponibilizadas pelo RIIVT proposto compensa nitidamente as alterações necessárias aos dispositivos legais. 


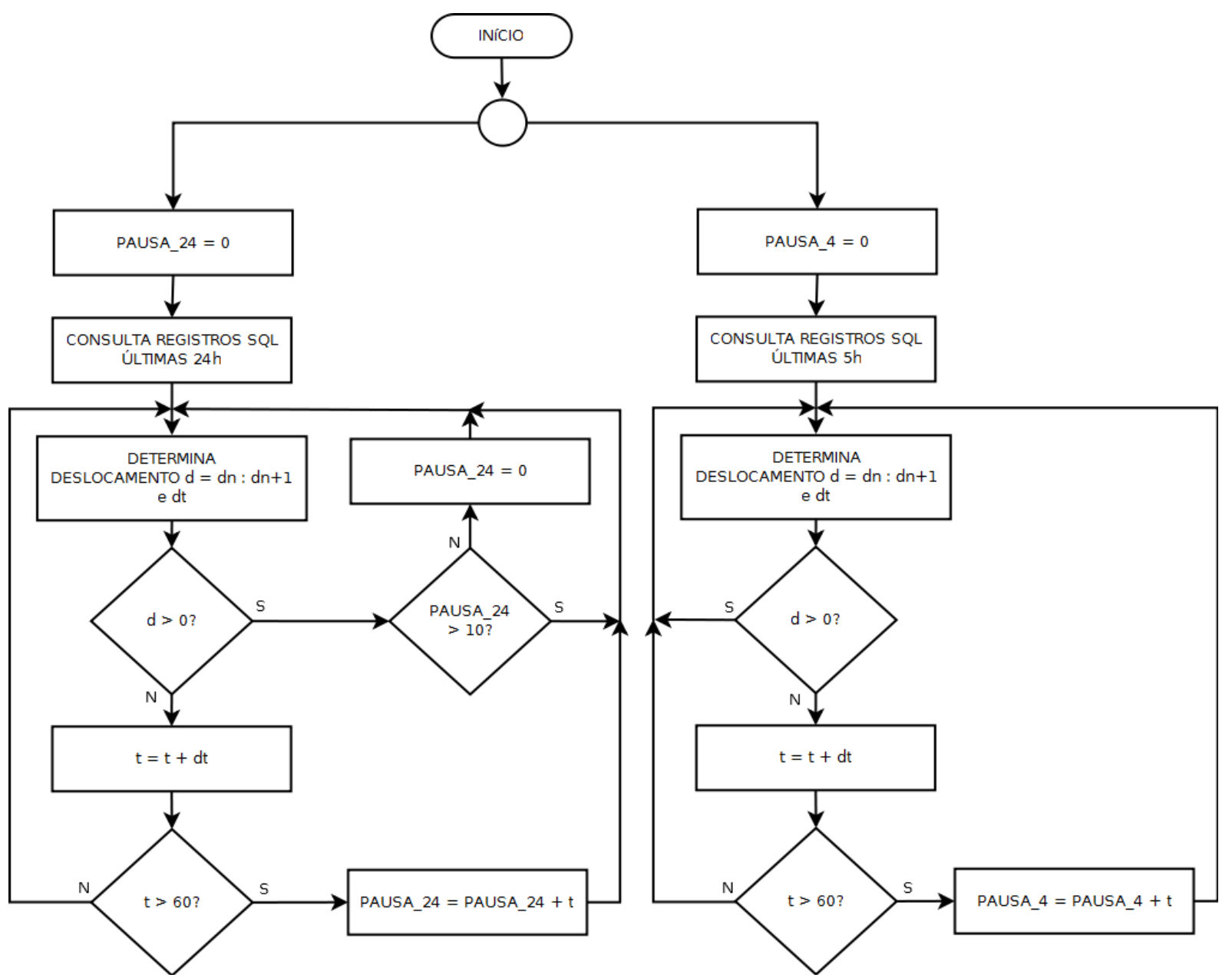

Figura 3-15 - Diagrama de blocos do programa de análise. 


\section{RESULTADOS E DISCUSSÕES}

\subsection{Condições de ensaio para a validação dos subsistemas}

O cenário ideal para a realização dos testes de validação do sistema como um todo seria a instalação dos sensores em um veículo de carga e registrar as suas informações de deslocamento. Contudo, não foi possível obter um veículo de carga que pudesse ficar a disposição para a instalação dos sensores e depuração do sistema. Dessa forma adotou-se um veículo de passeio para a realização dos testes, um FIAT Pálio ELX 1.4, ano de fabricação 2008.

\subsection{Teste do receptor GPS}

O método para verificação do funcionamento do módulo GPS consistiu em confrontar a leitura produzida pelo instrumento com as informações de um local geograficamente conhecido e oficialmente documentado. $\mathrm{O}$ ponto de referência selecionado foi a estação gravimétrica do Sistema Geodésico Brasileiro, localizada no município de Lins-SP, que segundo o IBGE (1998) está localizado nas coordenadas geográficas de latitude -21,674444 e longitude $-49,751667$. 
Levando-se o módulo GPS até o marco da estação gravimétrica, realizou-se uma leitura que indicava as coordenadas latitude - 21,674877 e longitude -49,751603, conforme pode ser visto na imagem da Figura 4-1.

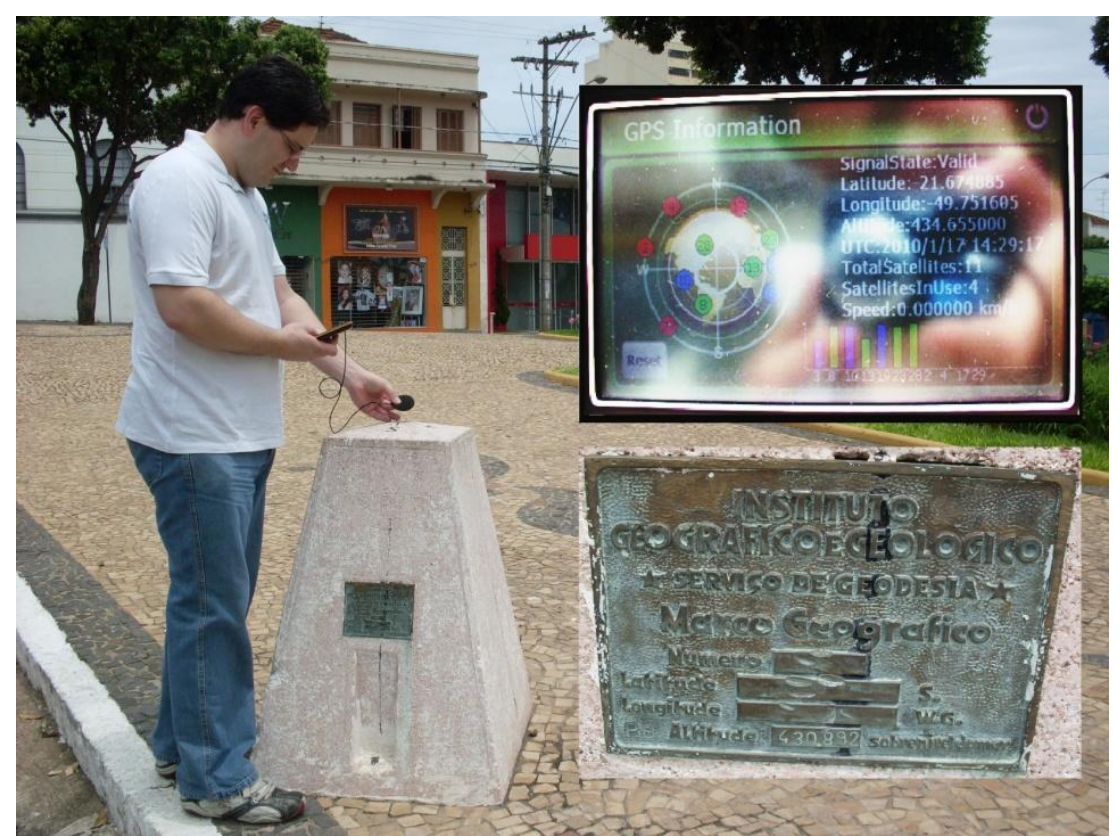

Figura 4-1 - Processo de verificação da acuracidade do receptor GPS.

Fazendo uso da Equação 4-1 sugerida por Chamone (2009), calculou-se a distância geográfica entre as coordenadas documentadas e as coordenadas obtidas através do módulo GPS e obteve-se um erro de 48,6 metros entre a posição documentada e a aferida pelo instrumento, o que pode ser considerado adequado para a aplicação neste projeto. Isso se deve ao fato de que as informações de deslocamento do veículo são baseadas também na velocidade instantânea do veículo e não apenas no calculo de sua posição absoluta que é influenciada pelos erros de DOP.

$$
d=R_{t} * \cos ^{-1}\left(\cos \frac{\pi *\left(90-L a t_{b}\right)}{180} * \cos \frac{\pi *\left(90-L a t_{a}\right)}{180}+\sin \frac{\pi *\left(90-L a t_{b}\right)}{180} * \sin \frac{\pi *\left(90-L a t_{a}\right)}{180} * \cos \frac{\pi *\left(L g_{a}-L g_{b}\right)}{180}\right)
$$

Equação 4-1 - Distância Geográfica

Onde: $\mathrm{R}_{\mathrm{t}}$ é o raio da Terra com aproximadamente 6371 quilômetros; $\operatorname{Lat}_{\mathrm{a}}, \mathrm{Lg}_{\mathrm{a}}, \mathrm{Lat}_{\mathrm{b}}$, $\operatorname{Lg}_{\mathrm{b}}$ são respectivamente as latitudes e longitudes dos pontos a e b. 
Desta maneira, comprovou-se que o instrumento é capaz de receber corretamente os sinais provenientes do satélite e determinar a sua posição geográfica dentro das especificações apresentadas pelo fabricante.

\subsection{Teste de criptografia e assinatura}

O teste de criptografia e assinatura consistiu em aplicar as regras de assinatura e criptografia descritas no item anterior em um arquivo de registro de deslocamento de teste. Para esta tarefa de criptografar e assinar os arquivos foram utilizados os softwares GNUPG, que é um software baseado apenas em linha de comando responsável por criar e gerenciar certificados, chaves e criptografar mensagens; e o software GPA - GNU Privacy Assistant que é uma interface gráfica para o GNUPG. Ambos os softwares são gratuitos e distribuídos sob a licença GNU Versão 3.

A diferença entre este procedimento de teste e o modelo efetivamente proposto é que, os certificados gerados não têm a assinatura de uma autoridade de nível superior que garanta a sua autenticidade, e as chaves pública e privada, de cada certificado gerado ficam armazenadas em arquivos no computador e não no cartão inteligente.

A imagem da Figura 4-2 exibe o software para geração de certificados e as chaves de teste geradas. Sendo uma de condutor, uma de autoridade policial e uma do equipamento RIIVT.

Observa-se ainda na Figura 4-2 que as chaves da autoridade policial e do condutor têm data de expiração e a do hardware não. Tal medida visa evitar custo de renovação da chave de hardware, que não deve sofrer alterações, e atender a legislação de trânsito, pois o certificado do motorista deve expirar junto com a sua habilitação. Quanto ao certificado do policial, ele também deve expirar segundo as regras da corporação. Este procedimento também evita que um cartão inteligente perdido continue indefinidamente válido. 


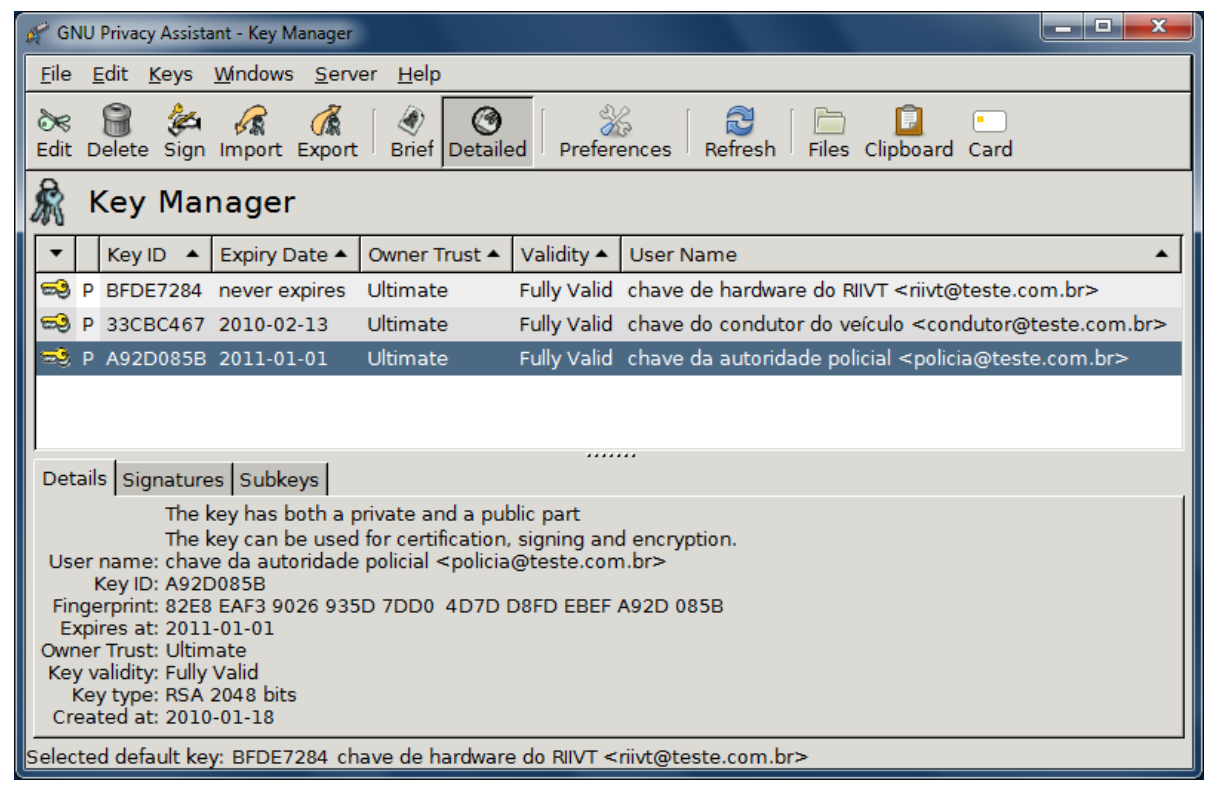

Figura 4-2 - Certificados digitais gerados para teste.

Assim, o arquivo de testes que simboliza aqui as mensagens de deslocamento gerado durante o trajeto do veículo de carga, foi digitalmente assinado utilizando-se do certificado do condutor. A imagem da Figura 4-3 exibe o arquivo de teste e o arquivo de assinatura gerado.

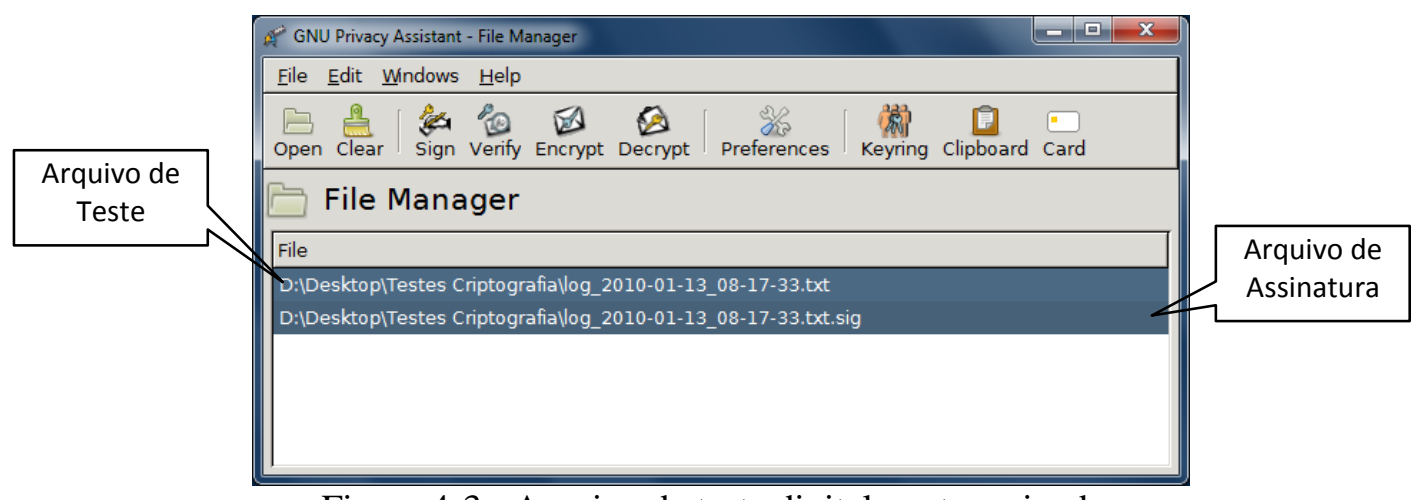

Figura 4-3 - Arquivo de teste digitalmente assinado.

Para verificar a autoridade e a integridade do arquivo assinado foi selecionada a opção Verify, que compara um hash instantâneo do arquivo em teste com o hash armazenado e criptografado do arquivo da assinatura. Se os valores forem coerentes o arquivo é dito válido. A imagem da Figura 4-4 exibe o resultado deste processo de verificação.

Para comprovar se este procedimento é mesmo efetivo, o arquivo de deslocamento foi alterado, removendo-se um único caractere de seu conteúdo. Isto feito o procedimento de 
verificação foi repetido. A imagem de Figura 4-5 exibe a informação que o arquivo agora alterado é inválido quanto ao conteúdo e quanto ao autor.

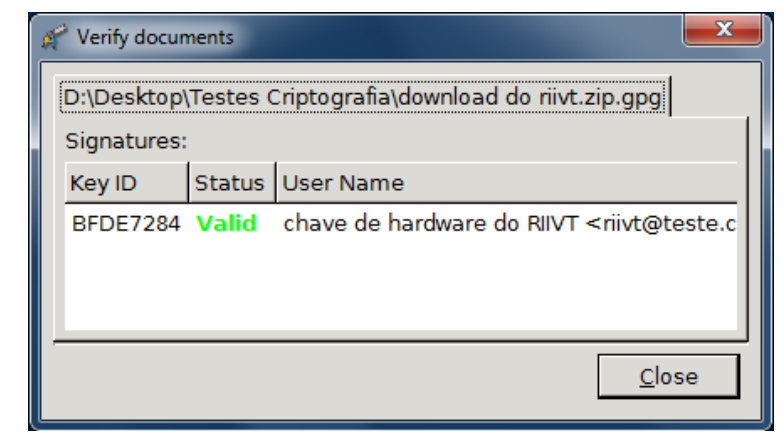

Figura 4-4 - Verificação válida de arquivo digitalmente assinado.

Estes testes demonstraram o funcionamento das técnicas de assinatura digital dos arquivos, demonstrando que se pode confiar na técnica de certificação proposta. Já para a transferência de arquivos entre o veículo e o equipamento de fiscalização existe a necessidade de realizar a criptografia do arquivo a fim de evitar que equipamentos próximos possam capturar os dados transmitidos ou ainda interferir no processo de comunicação introduzindo dados falsos.

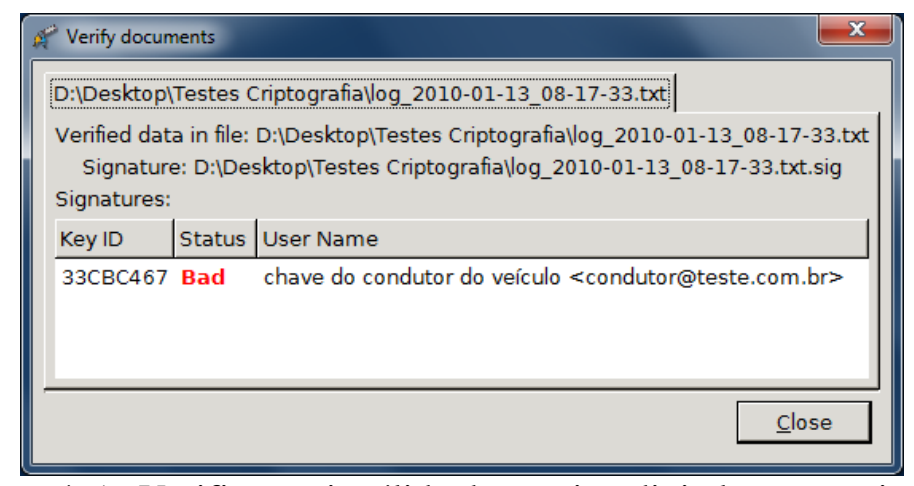

Figura 4-5 - Verificação inválida de arquivo digitalmente assinado.

Para isso o arquivo de registro de deslocamento e o seu respectivo arquivo de assinatura foram compactados com a finalidade de reduzir o seu tamanho em bytes, o que provoca diminuição considerável de espaço para armazenamento e tempo de transferência através da conexão sem fios. Após o processo de compactação o arquivo foi criptografado e assinado. A imagem Figura 4-6 exibe o processo de seleção das chaves para criptografia e assinatura. 


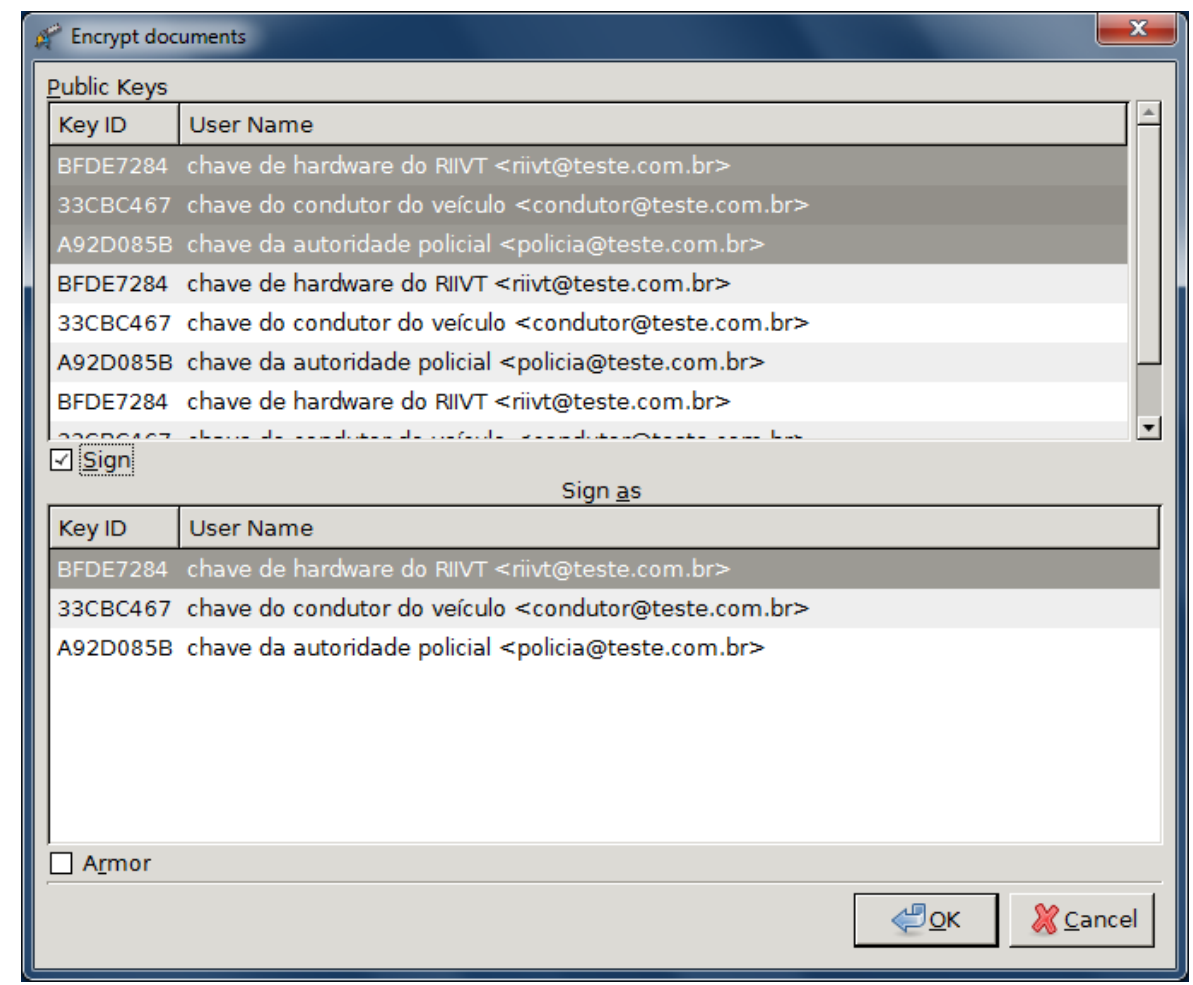

Figura 4-6 - Processo de criptografia e assinatura de arquivos para download.

A seção superior da tela do software exibe as chaves públicas utilizadas para criptografar o arquivo. Estes são os certificados que poderão descriptografar os arquivos posteriormente utilizando-se de suas chaves privadas. Já na sessão inferior da tela são exibidas as chaves utilizadas para a assinatura do arquivo.

Em todos os testes foram utilizadas chaves criptográficas RSA de 2048 bits, com tecnologia semelhante a adotada pelo modelo europeu de certificação. Verificou-se desta forma que o processo de certificação e criptografia é eficaz e atende as premissas fixadas para este projeto.

\subsection{Testes da conexão de rede sem fios}

O primeiro passo para a realização dos testes de conexão de rede sem fios foi a escolha de um local que atendesse os seguintes requisitos: disponibilidade de energia elétrica, segurança para os equipamentos e profissionais, segurança para realização de passagens a velocidades de até $110 \mathrm{~km} / \mathrm{h}$ e boas condições de propagação eletromagnética. 
O local escolhido foi o trecho da rodovia SP-300 - Marechal Rondon, dentro do município de Lins-SP, entre as saídas 442 e 445. Neste trecho estão localizados uma passarela para a travessia de pedestres sobre da rodovia e um posto da policia militar rodoviária estadual.

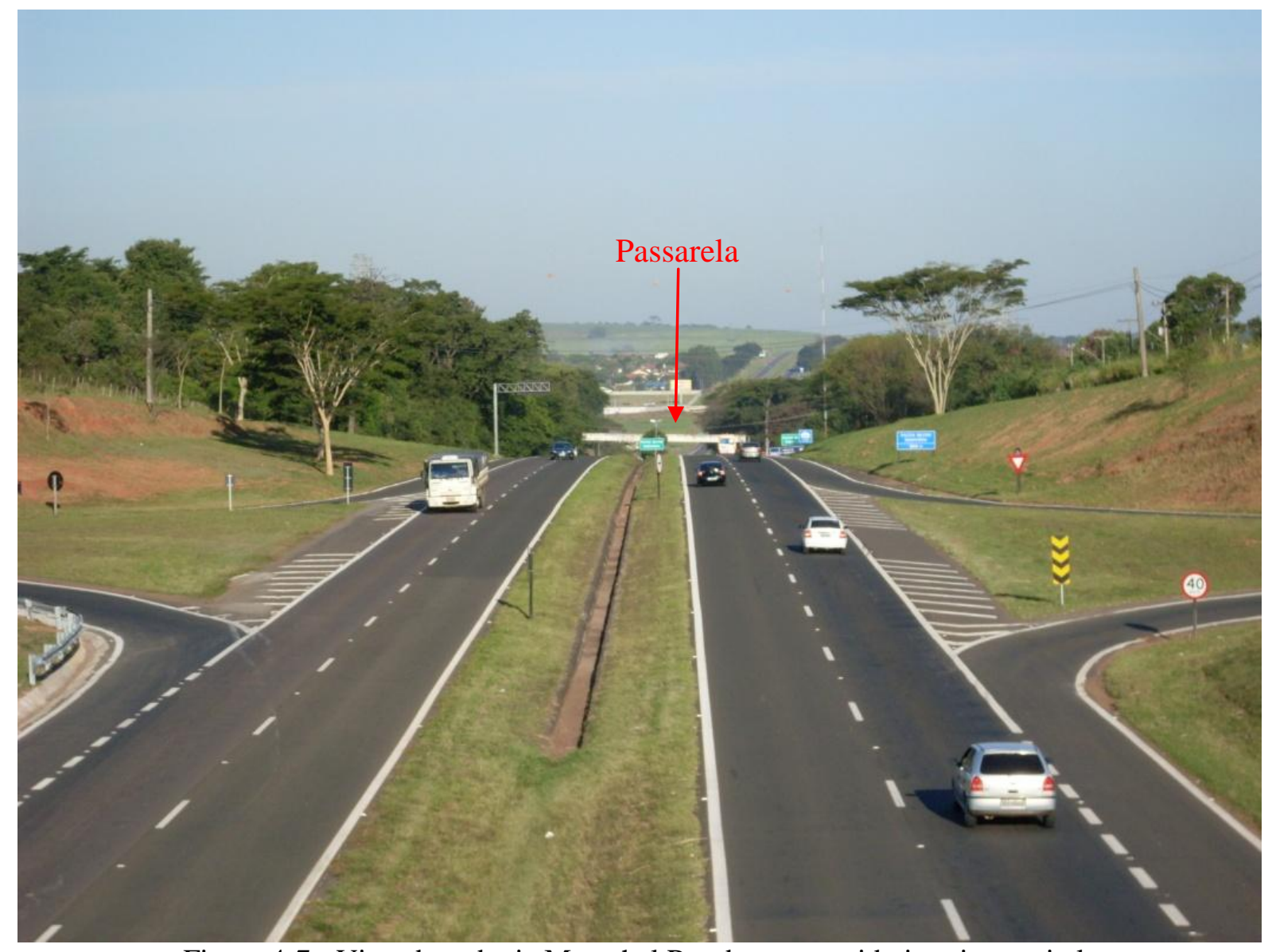

Figura 4-7 - Vista da rodovia Marechal Rondon no sentido interior-capital.

O ponto de acesso para a conexão sem fios entre o veículo de teste e o equipamento de fiscalização foi instalado sobre a passarela. Como não havia energia elétrica disponível naquele ponto foi providenciado um conversor DC/AC alimentado por baterias que supriu as necessidades do ponto de acesso e do computador pessoal utilizado como equipamento de fiscalização. O ponto de acesso foi posicionado no beiral da passarela sobre o eixo da pista sentido interior-capital, conforme ilustra a foto da Figura 4-8. 


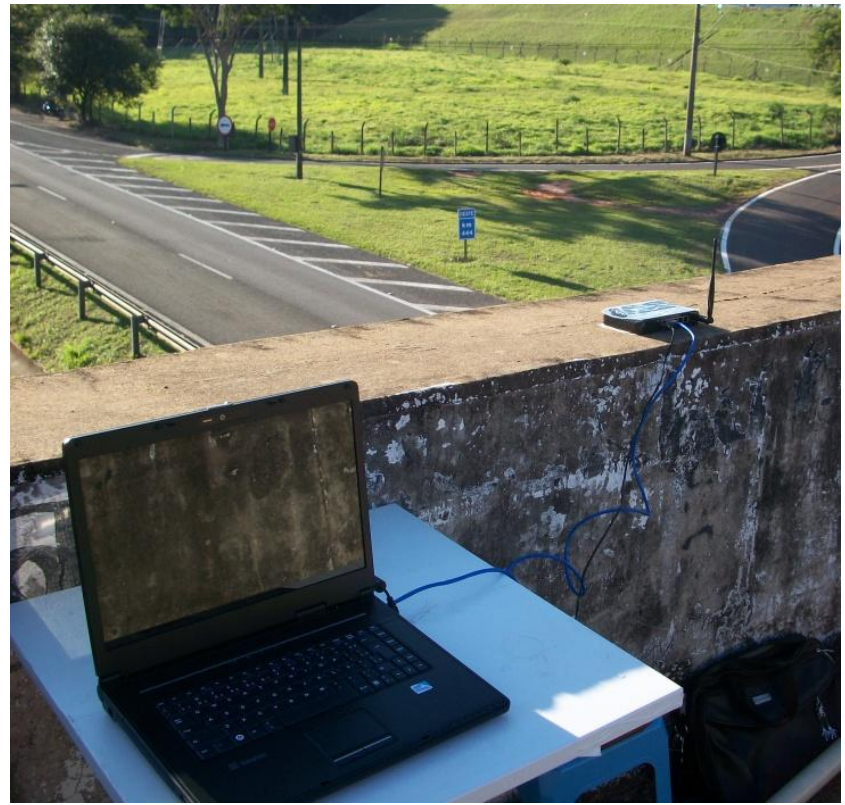

Figura 4-8 - Localização do ponto de acesso.

$\mathrm{O}$ veículo de testes foi então equipado para desempenhar a sua tarefa. $\mathrm{O}$ receptor de GPS e o adaptador de rede sem fios foram posicionados sob o teto do veículo e presos com ajuda de imãs. No interior do veículo, um computador pessoal executava o software Vistumbler dedicado a capturar a intensidade dos sinais de pontos de acesso e correlacionálos com as posições geográficas de modo a produzir um mapa dos sinais de rádio disponíveis. A Figura 4-9 exibe o veiculo de testes preparado.

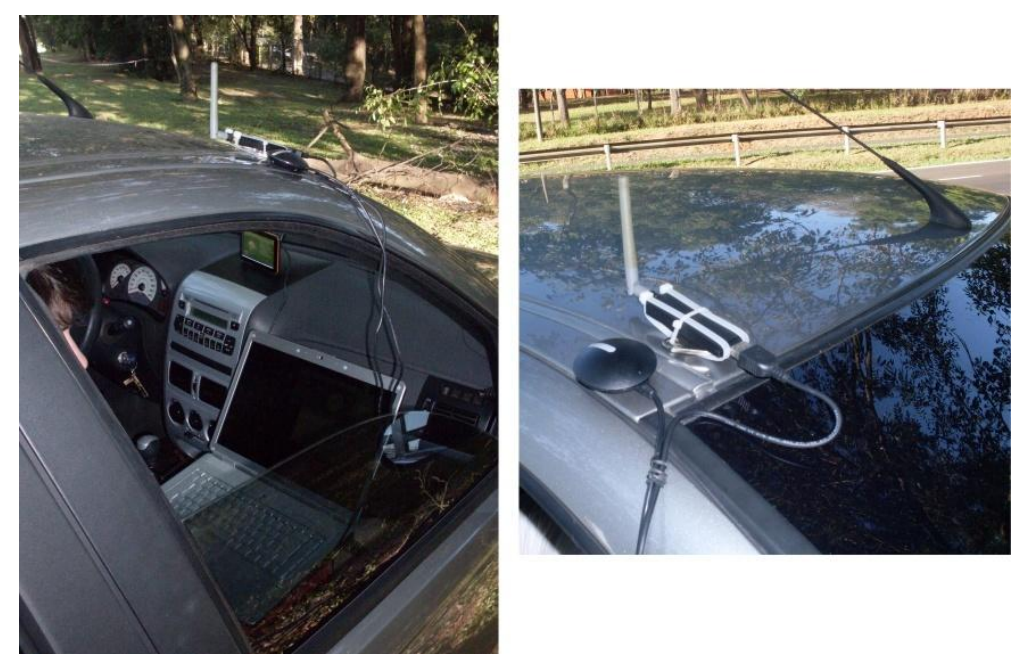

Figura 4-9 - Veículo de testes, no detalhe receptor GPS e interface de rede.

O veículo foi então posto em movimento, circulando pelo acostamento da pista a uma velocidade de aproximadamente $20 \mathrm{~km} / \mathrm{h}$. O trajeto realizado teve inicio na passarela, 
percorrendo pela pista no sentido interior-capital até a saída 442, contornado o retorno e voltando pela pista capital-interior até a saída 445, contornando novamente o retorno e terminando o trajeto junto à passarela. Neste trajeto foi possível obter um levantamento detalhado da propagação de ondas de rádio no trecho. O resultado deste levantamento foi então importado no software Google Earth a fim produzir uma imagem geograficamente referenciada dos pontos de acesso encontrados. O resultado pode ser visto na Figura 4-10.

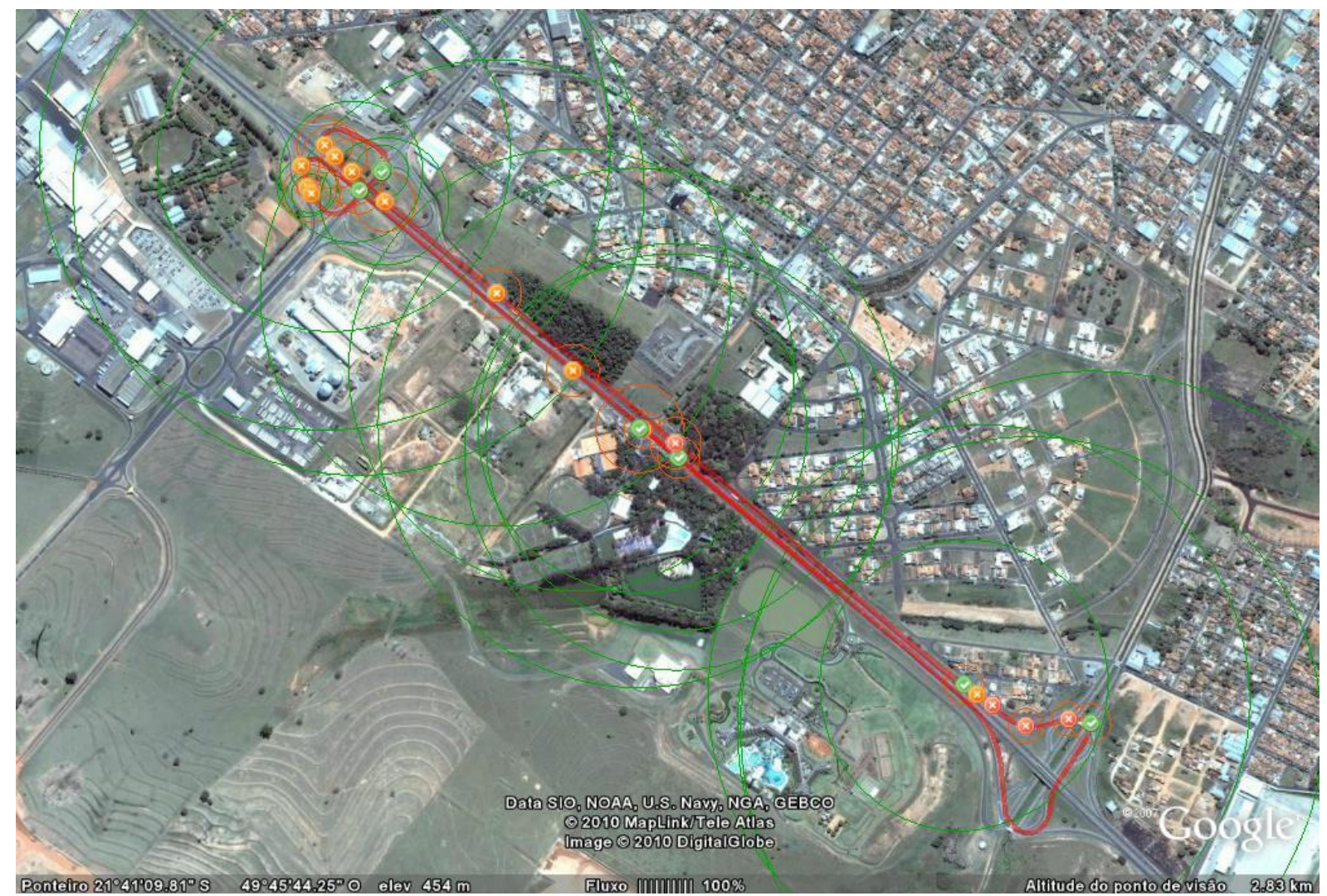

Figura 4-10 - Panorama dos pontos de acesso disponíveis no trecho de testes (Elaboração própria feita sobre imagem do serviço GOOGLE EARTH, Acessado em 17/10/2010).

As linhas na cor vermelha indicam o trajeto do veículo de testes na pista, as circunferências na cor verde indicam a área estimada de cobertura dos pontos de acesso, e as circunferências em cor alaranjada indicam a intensidade dos sinais efetivamente mensurados. Os círculos coloridos com símbolos em seu interior representam se o ponto de acesso é de acesso público ou restrito. As maiores concentrações de pontos de acesso foram localizadas na parte inferior direita da imagem, próximo à saída 442, onde se situa um bairro residencial 
de classe média-alta, e no canto superior esquerdo onde se encontra um parque industrial. No centro do trecho também podem ser visualizados dois pontos de acesso de um clube de campo próximo, além de um ponto de acesso da empresa concessionária da rodovia instalado próximo a base da policia militar rodoviária.

Além da informação de posição geográfica, o software Vistumbler reporta também quais os canais, ou frequiências de operação, em que os pontos de acesso estão funcionando. Felizmente havia um único canal que não estava sendo utilizado por nenhum ponto de acesso no trecho de testes, o canal 11. De forma que o ponto de acesso utilizado durantes os testes de passagem foi configurado para operar neste. Observe-se então que embora o espectro de radiofrequiência estivesse bastante congestionado no trecho isso provavelmente não causou interferência nos testes dado ao canal disponível.

Na seqüência o veículo de testes percorreu novamente o mesmo trajeto a fim de levantar as informações de propagação apenas do ponto de acesso da infra-estrutura de testes, ignorando-se os demais. Este resultado pode ser visto na Figura 4-11.

Observe-se que a representação do ponto de acesso, o circulo verde no centro da imagem, não está localizado exatamente sobre a passarela, local onde ele estava precisamente instalado. Este desvio pode ser devido a uma imprecisão do receptor GPS ou do próprio software Google Earth. A diferença entre a posição indicada do ponto de acesso e a sua efetiva posição foi de 23 metros.

O ponto de acesso foi configurado para operar no padrão IEEE 802.11g, utilizando-se de modulação OFDM, e transferindo dados a 54 Mbps. Nesta configuração o diâmetro de cobertura mensurado do ponto de acesso foi de 163,2 metros. Calcula-se que um veículo levaria aproximadamente 7 segundos para percorrer a área de cobertura a uma velocidade de $80 \mathrm{~km} / \mathrm{h}$. 


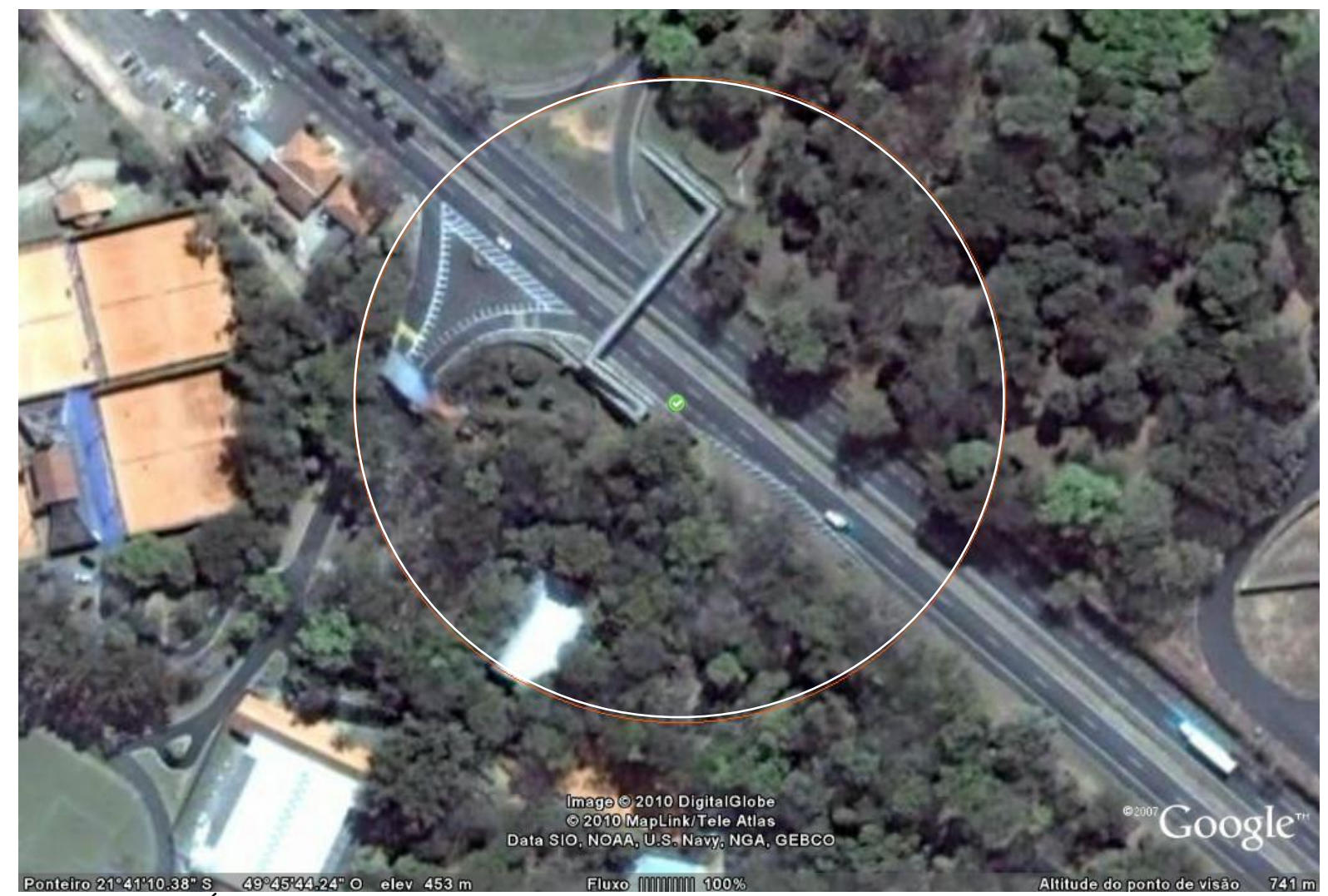

Figura 4-11 - Área de cobertura do ponto de acesso de testes (Elaboração própria feita sobre imagem do serviço GOOGLE EARTH, Acessado em 17/10/2010).

\subsection{Primeiro ensaio de passagem}

Ajustadas as condições de ensaio, o veiculo de testes foi equipado com o protótipo do RIIVT. O receptor de GPS e o adaptador de rede foram mantidos no lado externo do veículo, na mesma configuração mostrada na Figura 4-9.

Posto em funcionamento o RIIVT ele deveria se conectar ao ponto de acesso assim que estiver ao alcance e transmitir as informações sobre o tempo contínuo de condução e sobre a identificação de seu condutor.

Diferente do idealizado na descrição do software no capitulo anterior, este sistema não interrompe a conexão de rede ao realizar a transferência de dados. Para facilitar as mensurações durante os testes o RIIVT foi programado para transmitir contínua e repetidamente as suas informações enquanto houver uma conexão disponível. De forma a ser 
possível mensurar a duração total da conexão e quanta informação é passível de transmissão nesse ínterim.

O veículo de testes percorreu então o trecho especificado anteriormente, agora circulando adequadamente pela pista de rolamento, e respeitando as condições de segurança em função do trafego. Chama-se a atenção para o tráfego, pois na maior parte das passagens existiam outros veículos circulando no mesmo sentido e próximos ao veículo de teste.

As passagens foram registradas pelo software em execução no computador preparado para funcionar como equipamento de fiscalização, instalado junto ao ponto de acesso. A Tabela 4-1 resume os resultados obtidos no primeiro teste de passagem.

Tabela 4-1 - Resultados do primeiro teste de passagem.

\begin{tabular}{|c|c|c|c|c|c|c|}
\hline$\#$ & $\begin{array}{l}\text { Instante da } \\
\text { Conexão }\end{array}$ & $\begin{array}{l}\text { Duração da } \\
\text { Conexão [s] }\end{array}$ & $\begin{array}{c}\text { Velocidade } \\
\text { Média }[\mathrm{km} / \mathrm{h}]\end{array}$ & $\begin{array}{c}\text { Alcance } \\
\text { (Calculado) }[\mathrm{m}]\end{array}$ & $\begin{array}{c}\text { Dados Transferidos } \\
\text { [Bytes] }\end{array}$ & $\begin{array}{c}\text { Throughput } \\
\text { [Bytes/s] }\end{array}$ \\
\hline 1 & $14: 48: 14$ & 5 & 36,3 & 50,4 & 183 & 37 \\
\hline 2 & PERDIDO & - & - & - & - & - \\
\hline 3 & PERDIDO & - & - & - & - & - \\
\hline 4 & PERDIDO & - & - & - & - & - \\
\hline 5 & $15: 34: 39$ & 2 & 56,5 & 31,4 & 558 & 279 \\
\hline 6 & $15: 37: 24$ & 2 & 60,9 & 33,8 & 620 & 310 \\
\hline 7 & $15: 43: 03$ & 7 & 44,1 & 85,8 & 1736 & 248 \\
\hline 8 & $15: 49: 37$ & 1 & 54,6 & 15,2 & 310 & 310 \\
\hline 9 & $16: 02: 02$ & 5 & 39,2 & 54,4 & 1302 & 260 \\
\hline 10 & PERDIDO & - & - & - & - & - \\
\hline 11 & PERDIDO & - & - & - & - & - \\
\hline 12 & $*$ & - & - & - & - & - \\
\hline 13 & $17: 18: 13$ & $<1$ & 90,9 & 25,3 & 186 & 186 \\
\hline 14 & $17: 22: 11$ & 7 & 93,5 & 181,8 & 1488 & 213 \\
\hline 15 & $17: 26: 23$ & 15 & 84,2 & 350,8 & 2604 & 174 \\
\hline
\end{tabular}

O asterisco na décima segunda linha da tabela indica que houve um problema com o computador pessoal que realizava a tarefa de equipamento de fiscalização. Ele travou a execução do programa e precisou ser reiniciado. Concomitante a isso houve o esgotamento das baterias do conversar DC/AC que alimentava o ponto de acesso. Deste modo o teste foi interrompido para a recarga das baterias tendo prosseguido a partir daí. 
A coluna da velocidade média apresenta a velocidade média do veículo de testes durante a passagem. Explica-se que durante uma única passagem o RIIVT transmitiu diversos pacotes que refletiam a velocidade no veículo naquele instante. Como o veiculo de testes seguia a tendência do tráfego local, ora o condutor imprimia um ritmo de aceleração, ora de frenagem. Em função disso calculou-se a velocidade média durante a passagem. $\mathrm{O}$ alcance foi calculado multiplicando-se a velocidade média da passagem, já convertida em metros por segundo, pelo intervalo de duração da conexão, a fim de confrontá-la com a cobertura mensurada. O Throughput, que é taxa efetiva de dados transmitidos por unidade de tempo, Tanenbaun (1997), foi calculado dividindo-se a totalidade de bytes transferidos pela duração da conexão.

De posse destes dados calculou-se então os valores da transferência média de dados por passagem, 999 Bytes/Passagem; o throughput médio da conexão, 224 Bytes/s; duração média da conexão, 5s; e um alcance médio efetivo de 92,1 metros.

A análise cuidadosa destes dados mostra um resultado abaixo do esperado, pois não houve conexão bem sucedida em 5 das 15 passagens realizadas. Tal resultado inviabiliza o emprego de IEEE 802.11g para a finalidade pretendida. O alcance médio mostra-se também bastante inferior ao aos 163,2 metros aferidos durante o teste de intensidade de sinal.

$\mathrm{Na}$ busca dos motivos que poderiam ter produzidos os resultados negativos deparou-se com um recurso do ponto de acesso chamado de auto fallback. O fallback é uma rotina presente no software do ponto de acesso que monitora constantemente a relação sinal/ruído da conexão com um adaptador de rede remoto. Quando esta relação sinal/ruído caí abaixo de valores pré-definidos o ponto de acesso realiza uma comutação de sua modulação, rebaixando-a para uma das técnicas mais robustas, porém de menor taxa de transmissão. Este recurso garante com que adaptadores de rede que estejam dentro da área de cobertura, mas movimentando-se para fora da mesma permaneça conectado por mais tempo à custa de uma 
conexão com taxa de transmissão mais baixa. Observa-se porém que o movimento inverso também produz alterações, ou seja, um adaptador de rede que esteja se movendo para dentro da área de cobertura terá a sua taxa de transmissão aumentada a medida que melhora a sua relação sinal/ruído.

O impacto deste recurso no projeto do RIIVT é que os equipamentos de rede gastam grande parte do pequeno intervalo de tempo disponível para a conexão negociando as taxas de transmissão. Se levarmos em consideração que os equipamentos possuem, no padrão $802.11 \mathrm{~g}$, 12 opções de taxas de transmissão disponíveis, têm-se a dimensão do tempo desperdiçado nessa negociação.

Além disso, a estrutura de aço e concreto, bastante espessos, da passarela poderia estar atenuando fortemente o sinal de baixa intensidade do ponto acesso. A atenuação poderia inclusive estar produzindo uma região de sombra que estaria inclusive produzindo uma desconexão breve do adaptador de rede. Em função destas observações decidiu-se pela realização de um novo ensaio.

\subsection{Segundo ensaio de passagem}

O segundo ensaio de passagem foi realizado exatamente no mesmo trecho do ensaio anterior para permitir estabelecimento de comparações. Contudo, procurou-se evitar o posicionamento do ponto de acesso sobre a passarela para evitar as possíveis regiões de sombra.

A solução para evitar que o recurso de auto fallback do ponto de acesso fosse acionado foi fixar o funcionamento do mesmo no padrão 802.11 b, e fixar também a taxa de transmissão em 1 Mbps, a menor taxa de transmissão disponível. O ponto de acesso foi instalado sobre um pilar de sustentação junto ao posto da polícia militar rodoviária. A Figura 4-12 exibe a nova localização do ponto de acesso. 


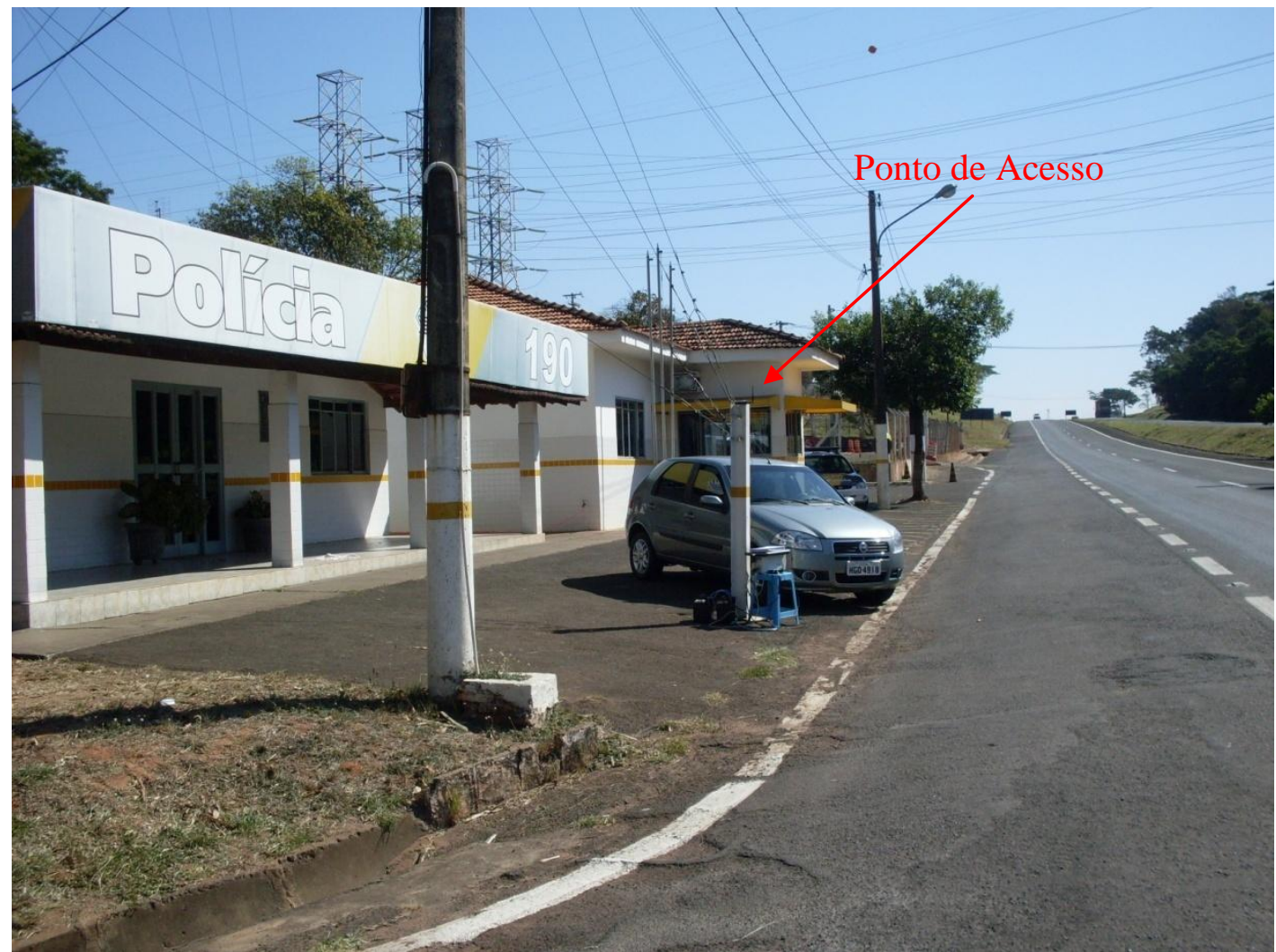

Figura 4-12 - Nova localização do ponto de acesso.

Nota-se no lado direito da imagem que a pista de rolamento no sentido capital interior está num nível mais alto do que a pista interior - capital. Porém o posicionamento do ponto de acesso acima do pilar de sustentação manteve-o visualmente em um nível acima do pavimento capital - interior de modo a não causar interferências na comunicação.

Realizou-se então novo procedimento para mensuração das condições de propagação dos sinais, no trecho de teste, após o reposicionamento do ponto de acesso. O resultado deste novo procedimento, após processamento no Google Earth pode ser visto na imagem da Figura 4-13.

Note-se que neste levantamento não ocorreu o deslocamento da posição da localização do ponto de acesso com relação do mapa. Isso mostra que o erro ocorrido no ensaio anterior pode dever-se a erro de DOP no receptor de GPS. 


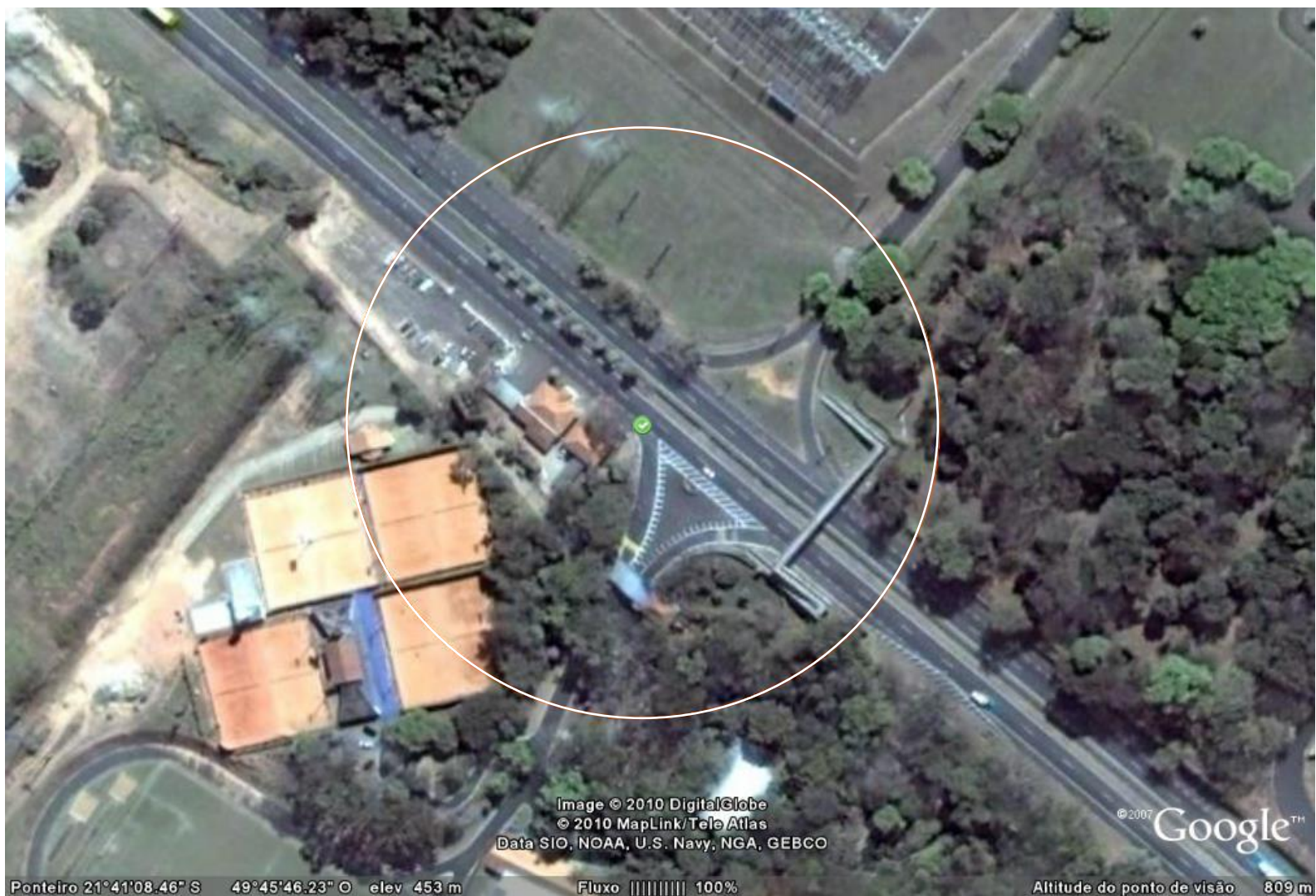

Figura 4-13 - Área de cobertura da nova posição do ponto de acesso de testes (Elaboração própria feita sobre imagem do serviço GOOGLE EARTH, Acessado em 17/10/2010).

Outra mudança importante foi a ampliação da área de cobertura, saltando dos 163,2 metros de diâmetro para 183,08 metros de diâmetro. Um incremento de $11 \%$ na área de cobertura. Realizados os testes de passagem, nos mesmos moldes do ensaio anterior, os dados foram coletados e consolidados na Tabela 4-2.

Já na primeira observação é possível detectar que não houve passagens com perda de conexão, o que denota o sucesso das alterações realizadas. O segundo teste, entretanto não teve as mesmas 15 passagens do primeiro em função da descarga das baterias do conversor DC/AC que se esgotaram antes do término do ensaio. Nota-se porém que mesmo com diferente número de passagens que o desempenho, no segundo, foi tecnicamente superior.

As condições de tráfego durante a realização do segundo ensaio eram visivelmente semelhantes às encontradas durante a realização do primeiro teste. Com os dados consolidados da Tabela 4-2 calculou-se então a transferência média de dados por passagem, 
3582 Bytes/Passagem; o throughput médio da conexão, 230 Bytes/s; duração média da conexão, 15s; e um alcance médio efetivo de 264,2 metros.

Tabela 4-2 - Resultados do segundo teste de passagem.

\begin{tabular}{|r|c|c|c|c|c|c|}
\hline$\#$ & $\begin{array}{c}\text { Instante da } \\
\text { Conexão }\end{array}$ & $\begin{array}{c}\text { Duração da } \\
\text { Conexão [s] }\end{array}$ & $\begin{array}{c}\text { Velocidade } \\
\text { Média [km/h] }\end{array}$ & $\begin{array}{c}\text { Alcance } \\
\text { (Calculado) [m] }\end{array}$ & $\begin{array}{c}\text { Dados Transferidos } \\
\text { [Bytes] }\end{array}$ & $\begin{array}{c}\text { Throughput } \\
\text { [Bytes/s] }\end{array}$ \\
\hline 1 & $11: 42: 09$ & 4 & 82,6 & $91,8($ Min) & 868 & 217 \\
\hline 2 & $12: 17: 09$ & 7 & 59,7 & 116,1 & 1550 & 221 \\
\hline 3 & $12: 19: 36$ & 17 & 65,4 & 308,8 & 3534 & 208 \\
\hline 4 & $12: 21: 55$ & 15 & 64,0 & 266,7 & 3410 & 227 \\
\hline 5 & $12: 24: 32$ & 17 & 64,3 & 303,6 & 4092 & 241 \\
\hline 6 & $12: 27: 02$ & 6 & 61,7 & 102,8 & 1178 & 196 \\
\hline 7 & $12: 29: 30$ & 19 & 62,4 & $329,3($ Max) & 4464 & 235 \\
\hline 8 & $12: 31: 47$ & 17 & 61,2 & 289,0 & 3968 & 233 \\
\hline 9 & $12: 34: 10$ & 16 & 65,0 & 288,9 & 3596 & 225 \\
\hline 10 & $13: 17: 37$ & 27 & 54,1 & 405,8 & 6572 & 243 \\
\hline 11 & $13: 20: 33$ & 16 & 62,6 & 278,2 & 3844 & 240 \\
\hline 12 & $13: 22: 52$ & 16 & 60,8 & 270,2 & 4092 & 256 \\
\hline 13 & $13: 25: 18$ & 22 & 62,8 & 383,8 & 5394 & 245 \\
\hline
\end{tabular}

Ou seja, embora o throughput médio da conexão tenha sofrido um decréscimo de 2,6\% com a redução da taxa de transmissão, o tempo médio da conexão saltou de 5 para 15 segundos, o que teve impacto direto na quantidade de informação transferida, num acréscimo de $358 \%$. Isso comprova a robustez da modulação de baixa taxa de transferência e mostra que essa redução da taxa de transmissão não compromete o desempenho global do sistema. A maior duração da conexão, provocada por melhores condições de propagação do sinal trazem mais segurança ao sistema, pois ampliam a área de cobertura impedindo que ocorra a passagem sem conexão e a consequente perda de informações. Há de observar também que o alcance da conexão, que é calculado em função do tempo de conexão multiplicado pela velocidade média do veículo de teste também aumentou. Ficando inclusive superior ao mensurado com o software Vistumbler. Isso pode ser devido a condições de reflexão dinâmicas não avaliadas.

A imagem da Figura 4-14 demonstra uma comparação entre as diferentes áreas de cobertura ocorridas nos ensaios. A circunferência de cor verde é a área de cobertura 
mensurada no primeiro ensaio. Já a circunferência vermelha apresenta a área de cobertura efetiva, reduzida em função do auto fallback.

A circunferência azul delimita a cobertura mensurada no segundo ensaio, e a circunferência amarela a efetiva área de cobertura no segundo ensaio. Atribui-se esta ampliação da área de cobertura em função do rápido estabelecimento da conexão e da presença de obstáculos refletivos que contribuem com o aumento da propagação na modulação utilizada.

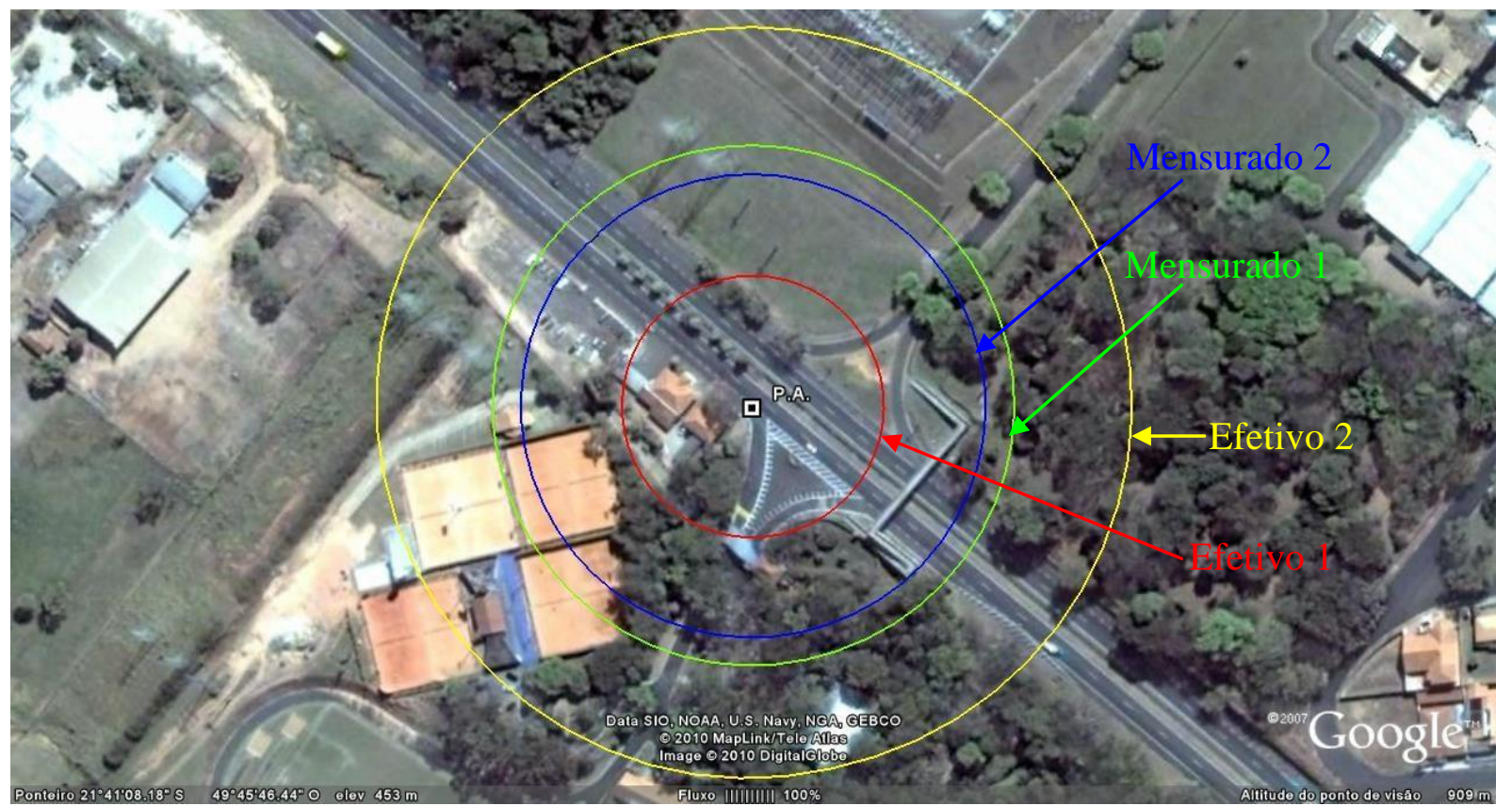

Figura 4-14 - Comparativo das áreas de cobertura (Elaboração própria feita sobre imagem do serviço GOOGLE EARTH, Acessado em 17/10/2010).

Registrando-se as quantidades de dados transferidos contra a velocidade média de cada passagem em um gráfico de dispersão resulta na Figura 4-15. Este gráfico permite imaginar que, quanto maior a velocidade do veículo de testes menor a quantidade de dados transferidos entre o veículo e o ponto de acesso. Isso pode ser verificado traçando-se uma curva de tendência exponencial que passe pelos dados coletados. Este resultado pode ser visualizado na Figura 4-15, com traço solido. 
Contudo, esse fato precisa de uma analise estatística que embase a sua afirmação. E para isso é necessário a realização de novos testes, com um numero maior de amostras delineadas em um experimento específico, o que não se justifica antes da publicação da norma IEEE 802.11p.

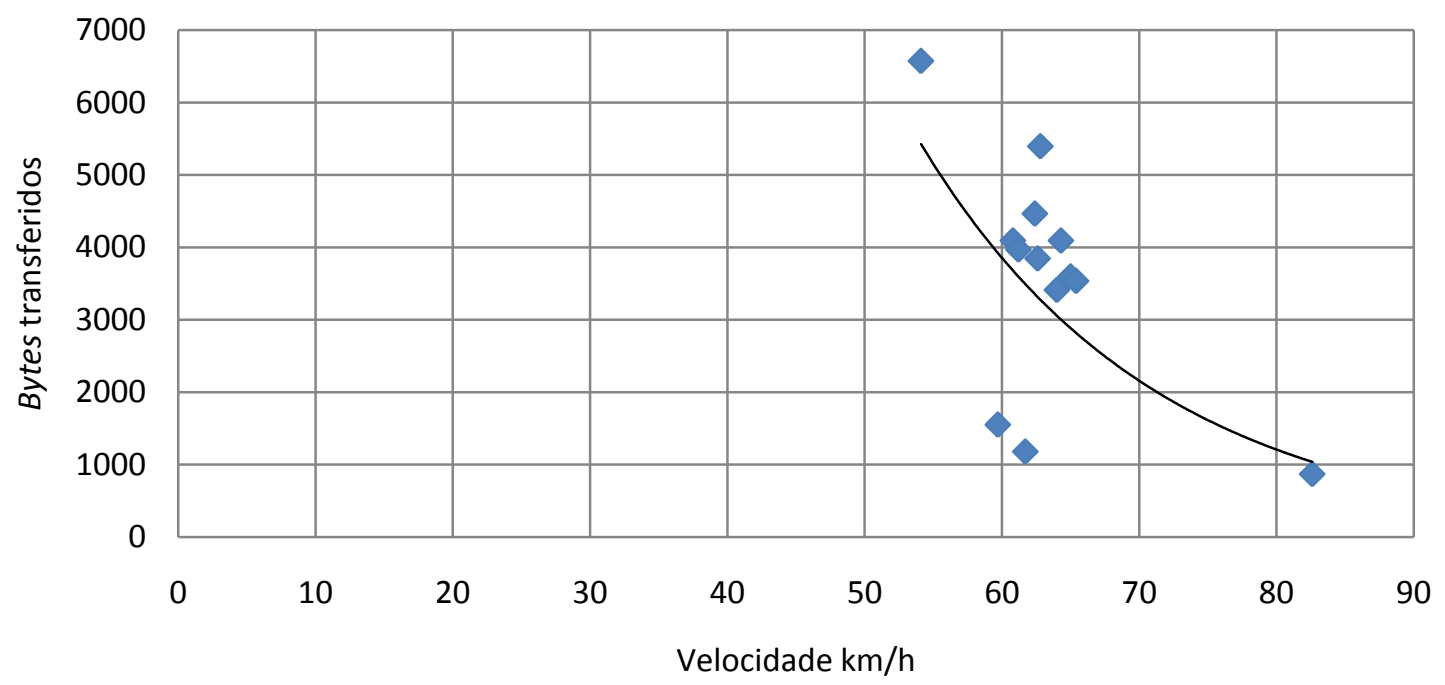

Figura 4-15- Gráfico da velocidade do veículo x quantidade de bytes transferidos.

Com base no exposto é possível concluir que se obteve êxito no segundo teste de conexão usando a norma IEEE 802.11b a uma taxa de transmissão de 1 Mbps. Isso demonstra que a escolha do padrão 802.11, embora não recomendado para a aplicação, atende perfeitamente às necessidades do projeto do RIIVT.

\subsection{Custos do equipamento}

Um dos requisitos do projeto do RIIVT, especificado nos capítulos anteriores, era que o seu custo ficasse próximo ao custo de RIIVT digital convencional incentivando-se assim a adoção do equipamento sugerido. Em dezembro de 2010, esse custo era de $\mathrm{R} \$ 1.500,00$ no mercado formal Brasileiro.

Observa-se que não foram computados os custos humanos com as horas de pesquisa para o desenvolvimento do mesmo ou ainda os custos decorrentes de sua produção em escala 
ou de documentação. Sabe-se que estes custos existem e não podem ser desprezados por quem deseja tornar este projeto de RIIVT em um produto comercial. Mas a realização deste orçamento desvia a atenção técnica e por este motivo foi suprimido. A Tabela 4-3 apresenta os custos de aquisição dos componentes principais.

Tabela 4-3 - Estimativa dos custos do projeto.

\begin{tabular}{|l|c|c|}
\hline \multicolumn{1}{|c|}{ Equipamento } & Custo & Impostos \\
\hline Placa de processamento Beagleboard & $\mathrm{R} \$ 321,30$ & $\mathrm{R} \$ 238,00$ \\
\hline Hub USB & $\mathrm{R} \$ 11,93$ & $\mathrm{R} \$ 7,14$ \\
\hline Leitor e cartão smart card & $\mathrm{R} \$ 12,31$ & $\mathrm{R} \$ 7,38$ \\
\hline Receptor de GPS & $\mathrm{R} \$ 64,41$ & $\mathrm{R} \$ 38,64$ \\
\hline Adaptador de Rede sem fios & $\mathrm{R} \$ 40,12$ & $\mathrm{R} \$ 24,07$ \\
\hline Fonte de alimentação & $\mathrm{R} \$ 8,50$ & $\mathrm{R} \$ 5,10$ \\
\hline Sub-total & $\mathrm{R} \$ 458,57$ & $\mathrm{R} \$ 320,33$ \\
\hline Total & \multicolumn{2}{|c|}{$\mathrm{R} \$ 778,90$} \\
\hline
\end{tabular}

Portanto, o custo de aquisição dos componentes que compõem o RIIVT perfaz um total de $\mathrm{R} \$ 778,90$, com impostos inclusos e a preço de varejo.

O elemento que agrega maior custo ao sistema proposto é a placa da unidade de processamento de dados. Grande parte do seu valor de aquisição está ligada aos impostos de importação que acresce $60 \%$ do seu custo no exterior, em taxas. Um agravante é que o país não possui uma indústria de semicondutores de alto desempenho como os utilizados neste projeto, de maneira que a importação deste sub-sistema é irremediável.

Contudo, a presença de computadores de informação e entretenimento nos veículos é cada vez maior. Isso sinaliza que a presença de um sistema computacional embarcado dedicado unicamente à fiscalização será desnecessária. Tornando-se este um serviço obrigatório agregado ao sistema computacional embarcado do veículo. Reduzindo-se assim um pouco mais o custo global de instalação do sistema.

Independente destes redutores, se considerarmos o custo estimado de aquisição dos componentes, detalhados acima, e o majorarmos em $300 \%$ para diminuir a possibilidade de 
sub-dimensionamento dos custos extras, têm-se um valor aproximado de $\mathrm{R} \$ 2.336,70$. Se considerarmos a instalação do RIIVT em cada um dos três milhões e quatrocentos mil veículos de carga registrados no país, têm-se um esforço de implantação estimado em $\mathrm{R}$ \$7.944.780.000. Valor este que embora significativo para um país em desenvolvimento, corresponde a um investimento $16 \%$ superior aos gastos com acidentes de trânsito no Brasil apenas no ano de 2005.

Já os custos de instalação da infra-estrutura de comunicação nas vias, são semelhantes aos da instalação de radares fixos.

\subsection{Discussões finais}

\subsubsection{Quanto às dificuldades jurídicas}

Embora este trabalho seja uma obra técnica de engenharia, faz-se necessário apresentar uma discussão dos aspectos jurídicos que a envolvem. A adoção do modelo de fiscalização proposto enfrentará forte oposição daqueles que temem pelo seu direito à privacidade. E estas pessoas não estão erradas. Os sistemas computacionais, embora repletos de artifícios matemáticos para garantir a privacidade, são tão seguros quanto às pessoas que os desenvolvem. E por isso exigem constante vigilância e contestação daqueles que primam pelos seus direitos.

Cabe a àqueles que administram tais sistemas a responsabilidade de agir de forma transparente, aceitando a análise crítica de terceiros e zelando pelas informações privilegiadas de que dispõem. Infelizmente não é isso que acontece no Brasil, talvez pela ausência de leis de responsabilidade específicas para os profissionais de tecnologia da informação.

A ausência de legislação específica para a jornada de trabalho de condutores de veículos de carga e transporte é outro problema. A auto-fiscalização, como executada em outros países, é ineficaz no Brasil devido a opressão econômica exercida sobre os condutores. 
A adoção do modelo proposto só se tornaria eficaz com um arcabouço legal que distribua proporcionalmente a responsabilidade entre o condutor, a empresa de transporte ou o proprietário do veículo de carga, e o contratante do serviço de transporte. Criminalizando a remuneração baseada em metas abusivas e definindo de modo científico uma jornada de trabalho humana e segura aos condutores profissionais.

\subsubsection{Quanto às dificuldades técnicas}

Como demonstrado, este projeto depende do sistema GPS para a medida de deslocamento e sincronia de relógio. De propriedade do governo dos Estados Unidos da América, sua adoção como equipamento obrigatório nos veículos de carga brasileiros seria uma situação no mínimo embaraçosa para o governo. Por outro lado, imaginar desenvolver semelhante sistema para atender os requisitos brasileiros seria proibitivo em função do seu alto custo e falta de experiência espacial.

Entretanto este problema não é exclusivamente brasileiro. Diversos projetos internacionais deste vulto encontram-se em compasso de espera pelo sistema de navegação via satélite da comunidade européia, chamado Galileu, com inicio de operação previsto para 2013. Ou ainda pelo sistema GLONASS, de origem russa, e o COMPASS, de origem chinesa. Os sistemas russo e europeu sinalizam com uma interessante solução, que pode atender ao Brasil, pois estão aceitando sócios interessados na sua operação.

De qualquer maneira, ainda é possível abandonar o uso do sistema GPS e voltar à tomar as medidas de deslocamento através de derivações na caixa de câmbio. Embora voltem a ser necessárias as calibrações periódicas, as funcionalidades e facilidade de fiscalização previstas no objetivo seriam mantidas.

Um ponto de fragilidade a fraudes é a conexão entre o sistema computacional e o receptor USB. Uma pessoal mal intencionada poderia substituir o receptor de GPS oficial por 
um adulterado para minorar os valores de deslocamento. Isso pode ser resolvido equipando-se o receptor um chip criptográfico de identificação, permitindo que apenas receptores homologados possam se conectar ao sistema computacional.

O emprego do padrão de rede 802.11 para a conexão entre a infra-estrutura da via e o veículo de carga constitui-se de uma solução tecnicamente eficiente para o problema apresentado. Obviamente a revisão "p" do referido padrão constituirá uma solução muito mais eficiente para este serviço, mas ainda existem muitas discussões até a definição da norma.

Como afirmado anteriormente, o padrão de rede sem fios 802.11 pode ser considerado como um eletrodoméstico, sendo encontrada na grande maioria das residências de classe média-alta. Por isso, a poluição eletromagnética gerado pela instalação de muitos destes equipamentos na mesma área geográfica pode ser um impedimento a adoção deste projeto. Contudo, o padrão 802.11 prevê a utilização de 13 canais de rádio, dos quais somente 11 estão liberados para utilização pela ANATEL. Sugere-se então que estes dois outros canais sejam de uso dedicado à infra-estrutura das vias, intercalando-se o seu posicionamento para evitar interferências.

Embora não tenha sido previsto na concepção do RIIVT, observou-se durante o seu desenvolvimento a necessidade de um teclado para digitação de senha do usuário. Essa senha é necessária para permitir o acesso à chave de criptografia privada armazenada no smartcard. Para os testes a senha de acesso às chaves foi fixada no código do programa na forma de constantes. 


\section{CONCLUSÃO}

Baseado nos resultados dos ensaios descritos nos capítulos anteriores pode-se afirmar que a concepção do RIIVT apresentada atingiu todos os objetivos especificados. Nenhuma modificação nas características físicas do veículo foi necessária para o seu funcionamento e a comunicação sem fios funcionou perfeitamente a até $82 \mathrm{~km} / \mathrm{h}$.

O investimento de $\mathrm{R} \$ 778,90$ para o desenvolvimento do protótipo revela que este custou aproximadamente $52 \%$ do valor de um RIIVT comercial convencional. Embora não signifique que este seja o seu valor final para produção em escala, dá a dimensão das possibilidades de custo do mesmo.

A infra-estrutura de comunicação sem fios, totalmente baseada no padrão IEEE 802.11 permite o emprego de equipamentos convencionais. Dado ao grande número de fabricantes destes equipamentos, o seu custo de aquisição é bastante interessante, e uma aquisição em escala pode reduzir ainda mais este custos. O advento da revisão IEEE 802.11p introduzirá melhorias técnicas que abrirão novas possibilidades. Embora operando em banda ISM, o sistema proposto não opera na mesma freqüência do SINIAV, o que permitirá que ambos possam ser utilizados concomitantemente sem prejuízos. Desta forma veiculo e condutor poderão ser fiscalizados sem a necessidade de abordagem do veículo. 
A privacidade e autenticidade das informações enviadas pelo veículo foram garantidas através de algoritmos públicos de criptografia que embora não sejam invulneráveis exigem um esforço computacional muito grande para que sejam comprometidos, desestimulando assim a tentativa.

A estrutura de certificação descrita apresenta uma grande inovação frente às estruturas de certificação pesquisadas, pois propõe um sistema efetivo e ao mesmo tempo independente da criação de novas estruturas governamentais para tal. Além disso, faz uso de certificados digitais e cartões inteligentes de e-CPF que dispõem de vários fornecedores no mercado nacional o que fomenta as leis da livre concorrência.

\subsection{Sugestões para trabalhos futuros}

Como já dito anteriormente, a introdução obrigatória de um computador de uso geral e de um receptor de GPS nos veículos de carga abre interessantes possibilidades quando combinado com as iniciativas de identificação veicular SINIAV, e da identificação do condutor. Entre estas possibilidades sugere-se, de forma não restritiva, as seguintes para o desenvolvimento de trabalhos futuros: instrumentação da suspensão do veículo para o monitoramento e fiscalização de sobrecarga no mesmo; pagamento de pedágio proporcional a real utilização da via; registrador de dados para análise de acidentes de trânsito. 


\section{REFERÊNCIAS BIBLIOGRÁFICAS}

ACTIA. Manual de instruções do tacógrafo modelo SMARTACH. 2005. 108p.

ALVES, S. A matemática do GPS. Revista do professor de matemática. Edição 59. IMEUSP. 2006.

ANTT, Agência Nacional de Transporte Terrestre. Matriz de Transporte de Cargas no Brasil: Relatório 2007. <http://www.antt.gov.br/>. Acesso em: 12/08/2009.

BARBIERI, R.; BARBIERI N.; MELO, R. P. Estabilidade Lateral de Conjuntos de Veículos de Carga. 2006. Disponível em:

<http://www.transtech.com.br/arquivos/Estabilidade_Lateral_de_Conjuntos_de_Carga_rev.pd f>. Acessado em 18 out. 2009.

BOWLER, D.E.P. Optimisation Wlan For Broadband Access. The University of Adelaide. Disponível em: <http://www.eleceng.adelaide.edu.au/research/undergradprojects/archive/WLANoptimisation/ProjectOverview/WLANBackground_files/image004.gif >. Acesso em: $02 / 03 / 2010$

BRASIL. Lei N 9.503, de 23 de setembro de 1997. Institui o código de trânsito brasileiro. Diário Oficial da União, Brasília, DF, 24/09/1997, P. 21201. 
Portaria GM/MS No 737, de 16 de maio de 2001. Institui a política nacional de redução da mobimortalidade por acidentes e violências. Diário Oficial da União, Brasília, DF, 18/05/2001, Seção 1e.

Custos de acidentes de trânsito nas rodovias federais. Departamento Nacional de Infra-estrutura de Transportes. Diretoria Geral. Diretoria Executiva. Instituto de Pesquisas Rodoviárias. Rio de Janeiro, 2004. 33p.

. Resolução No 14, de 23 de fevereiro de 1998. Estabelece os equipamentos obrigatórios para a frota de veículos em circulação e dá outras providências. DENATRAN Departamento Nacional de Trânsito. Diário Oficial da União, Brasília, DF, 26/02/1998.

Resolução No 87, de 4 de maio de 1999. Dá nova redação à resolução No 14/98 e fixa prazos. DENATRAN Departamento Nacional de Trânsito. Diário Oficial da União, Brasília, DF, 06/05/1999.

Resolução No 92, de 4 de maio de 1999. Dispõe sobre requisitos técnicos mínimos do registrador instantâneo e inalterável de velocidade e tempo, conforme o Código de Trânsito Brasileiro. DENATRAN Departamento Nacional de Trânsito. Diário Oficial da União, Brasília, DF, 26/02/1998.

BRUIJN, H. D.; BERLO, M. K. Effect of e-enforcement in the netherlands. IEEE Technology and society maganize. Spring. 2006.

BTS, Bureau of Transportation Statistics, Modal Shares, Research and Innovative Technology Administration (RITA), U.S. Department of Transportation (US DOT), Preliminary 2002 data. Disponível em:

<http://www.bts.gov/programs/freight_transportation/html/dominant_mode.html>. Acesso em 29 dez. 2009.

CARLSON, R.; GERDES, J.; POWELL, J., Practical position and yaw rate estimation with GPS and differential wheelspeeds. Procedings of 6th International Symposium AVEC, Hiroshima, Japan, Set. 2002. 
CEL, Centro de Estudos em Logística COPPEAD / UFRJ. Acidentes no transporte rodoviário de cargas no Brasil (2006). Disponível em:

<http://www.centrodelogistica.com.br/new/fs-pesquisa.htm>. Acesso em: 17 out. 2009.

CEFTRU - Centro Interdisciplinar de Estudos em Transportes. Disponível em:

$<$ http://www.ceftru.unb.br/comunicacao/noticias-antigas/2007/siniav/>. Acesso em: 19 Jan. 2010.

CERTISIGN. Infra-estrutura de chaves públicas brasileira ICP-Brasil. Disponível em: <http://www.certisign.com.br/certificacao-digital/infra-estrutura-de-chave-publica/icp-brasil> . Acesso em: 17 Jan. 2010.

CHAMONE, L. C. Cálculo de distâncias aéreas e ângulo azimute. Faculdade de Matemática da Universidade Federal de Minas Gerais. 2009. Disponível em: <http://200.198.28.154/sistema_crv/banco_objetos_crv/\%7B3CF392EF-04B9-4C72-B0506FFF76E46D35\%7D_monografia-GPS-Reduzida2.pdf>. Acesso em: 16 Jan. 2010.

CNT, Confederação Nacional do Transporte, Boletim estatístico do setor 2009. Disponível em: < http://www.cnt.org.br/portal/arquivos/cnt/downloads/bol_estatistico/becnt_2005_12.pdf>. Acesso em 17 out. 2009.

, Confederação Nacional do Transporte, Boletim estatístico do setor 2005.

Disponível em: <

http://www.cnt.org.br/portal/img/arquivos/Boletim\%20Estatístico\%20CNT\%20\%202009.pdf>. Acesso em 17 out. 2009.

Confederação Nacional do Transporte, Pesquisa CNT de rodovias 2009: relatório gerencial. CNT : SEST : SENAT. Brasília, DF, 2009, 152 p.

Confederação Nacional do Transporte, Transporte de cargas no Brasil: Ameaças e oportunidades para o desenvolvimento do País, Diagnóstico e plano de ação. Brasília, DF, 2002. 
DANA, P. H. Global Positioning System Overview. Department of Geography, University of Texas at Austin, Revised: 05/01/2000 (first published in September, 1994), Disponível em: <http://www.colorado.edu/geography/gcraft/notes/gps/gps_f.html>, Acesso em: $12 / 02 / 2010$.

DANTU, R.; LANGLE, L. Are you a safe driver. International Conference on Computacional Science and engineering. Disponível em: <http://www.computer.org/portal/web/csdl/doi/10.1109/CSE.2009.331>. Acesso em: 10/ Nov. 2009.

DENATRAN, Departamento Nacional de Trânsito. Frota de Veículos. Disponível em: <http://www.denatran.gov.br/frota.htm>. Acesso em 29 dez. 2009.

, Departamento Nacional de Trânsito. Anuários Estatísticos de Acidentes de Trânsito no Brasil. Brasília, DF. 1999. Disponível em: <http://www.viasseguras.com/layout/set/print/os_acidentes/estatisticas/estatisticas_nacionais/anuarios_estatisti cos_do_denatran>. Acesso em 12 jul. 2009.

, Departamento Nacional de Trânsito. Anuários Estatísticos de Acidentes de Trânsito no Brasil. Brasília, DF. 2000. Disponível em: < http://www.viasseguras.com/layout/set/print/os_acidentes/estatisticas/estatisticas_nacionais/anuarios_estatisti cos_do_denatran>. Acesso em 12 jul. 2009.

, Departamento Nacional de Trânsito. Anuários Estatísticos de Acidentes de Trânsito no Brasil. Brasília, DF. 2001. Disponível em: < http://www.viasseguras.com/layout/set/print/os_acidentes/estatisticas/estatisticas_nacionais/anuarios_estatisti cos_do_denatran>. Acesso em 12 jul. 2009.

, Departamento Nacional de Trânsito. Anuários Estatísticos de Acidentes de

Trânsito no Brasil. Brasília, DF. 2002. Disponível em: < http://www.viasseguras.com/layout/set/print/os_acidentes/estatisticas/estatisticas_nacionais/anuarios_estatisti cos_do_denatran>. Acesso em 12 jul. 2009. 
Departamento Nacional de Trânsito. Anuários Estatísticos de Acidentes de

Trânsito no Brasil. Brasília, DF. 2003. Disponível em: < http://www.vias-

seguras.com/layout/set/print/os_acidentes/estatisticas/estatisticas_nacionais/anuarios_estatisti cos_do_denatran>. Acesso em 12 jul. 2009.

Departamento Nacional de Trânsito. Anuários Estatísticos de Acidentes de

Trânsito no Brasil. Brasília, DF. 2004. Disponível em: < http://www.vias-

seguras.com/layout/set/print/os_acidentes/estatisticas/estatisticas_nacionais/anuarios_estatisti cos_do_denatran>. Acesso em 12 jul. 2009.

Departamento Nacional de Trânsito. Anuários Estatísticos de Acidentes de

Trânsito no Brasil. Brasília, DF. 2005. Disponível em: < http://www.vias-

seguras.com/layout/set/print/os_acidentes/estatisticas/estatisticas_nacionais/anuarios_estatisti cos_do_denatran>. Acesso em 12 jul. 2009.

Departamento Nacional de Trânsito. Anuários Estatísticos de Acidentes de

Trânsito no Brasil. Brasília, DF. 2006. Disponível em: < http://www.vias-

seguras.com/layout/set/print/os_acidentes/estatisticas/estatisticas_nacionais/anuarios_estatisti cos_do_denatran>. Acesso em 12 jul. 2009.

Departamento Nacional de Trânsito. Anuários Estatísticos de Acidentes de

Trânsito no Brasil. Brasília, DF. 2007. Disponível em: < http://www.vias-

seguras.com/layout/set/print/os_acidentes/estatisticas/estatisticas_nacionais/anuarios_estatisti cos_do_denatran>.Acesso em 12 jul. 2009.

DULMAGE, J. et al. DSRC Prototype Testbed. UCLA Wireless Research and

Development. Disponível em:

<http://www.unwired.ee.ucla.edu/dsrc/dsrc_testbed_simple.htm>. Acesso em: 3 de Jan. 2010.

EICHLER, S. Performance Evaluation of the IEEE 802.11p WAVE Communication

Standard. IEEE Vehicular Technology Conference, 2007.

ERCA - European Root Certification Authority. Digital Tachograph System Certification

Practices Statement. Version 1.0. Disponível em: <http://dtc.jrc.it/text/index.html>. Acesso em: 12 Jan. 2010. 
FIP. Manual de instruções do tacógrafo modelo SPY32. 2006. 15p.

FIPE, Fundação Instituto de Pesquisas Econômicas. Índices de transporte de carga no setor rodoviário: Tonelagem total transportada. Disponível em: < http://www.fipe.org.br/web/index.asp?g=2\&aspx=/web/indices/idet/indices.aspx>. Acesso em 12 jul. 2009.

FMCSA - Federal Motor Carrier Safety Administration. Insterstate truck drivers guide to hours of service. Disponível em: <http://www.fmcsa.dot.gov/rulesregulations/topics/hos/index.htm> Acesso em: 23 dez. 2009.

GRANTURCO, T. MIDT - Monitoring of the implementation of the digital tachograph. Meeting Geneva. 14 de Mai. 2007. Disponível em: <www.eu-digitaltachograph.org>. Acesso em: 10/01/2020.

GUIA DO TRANSPORTADOR, Matriz do transporte de cargas no Brasil. Disponível em: <http://www.guiadotrc.com.br/Estatistica/matriz_transporte.asp>. Acesso em 29 dez. 2009.

IBGE, Instituto Brasileiro de Geografia e Estatística. Estimativas populacionais dos municípios Brasileiros. Disponível em:

<http://www.ibge.gov.br/home/estatistica/populacao/estimativa2009/default.shtm>. Acesso em 30 dez. 2009.

, Instituto Brasileiro de Geografia e Estatística. Área Territorial Oficial: Atualizado em 2002. Disponível em:

<http://www.ibge.gov.br/home/geociencias/cartografia/default_territ_area.shtm>. Acesso em 29 dez. 2009.

, Instituto Brasileiro de Geografia e Estatística. Brasil em síntese: Contas nacionais 2007. Disponível em:

<http://www.ibge.gov.br/brasil_em_sintese/tabelas/contas_nacionais_tabela01.htm>.Acesso em 12 out. 2009. 
Instituto Brasileiro de Geografia e Estatística. Sistema Geodésico Brasileiro:

Relatório de estação geodésica. Leitura realizada em: 14/07/1998. Disponível em:

<http://www.bdg.ibge.gov.br/bdg/pdf/relatorio.asp?L1=8000449>. Acesso em 17 Jan. 2010.

IEEE802. Disponível em: <http://www.ieee802.org/>. Acesso em: 28/04/2010.

IGT, Inspecção Geral do Trabalho de Portugal. Condições de trabalho nos transportes rodoviários. Disponível em:

http://www.igt.gov.pt/DownLoads/content/Transportes_Rodoviarios.pdf. Acesso em 05 nov. 2009.

IPEA, Instituto de Pesquisas Econômicas Aplicadas. Impactos sociais e econômicos dos acidentes de trânsito nas rodovias brasileiras, Relatório Executivo. Brasília, DF. 2006. $80 \mathrm{p}$.

INMETRO, Instituto Nacional de Metrologia, Normalização e Qualidade Industrial.

Cronotacógrafo Ensaios metrológicos e verificação: A história do tacógrafo. Disponível em: 〈http://cicma.inmetro.rs.gov.br/cronotacografo/redetecnica/historia-do-cronotacografo〉. Acesso em: 06 de Nov. 2009.

INTELLIDRIVE, U.S. Department of Transportation. VIIC Cooperative Policy Research Plan 2009 - 2013. Disponível em:

$<$ http://www.intellidriveusa.org/documents/WorkingGroupMeeting10-

2009/Henry_10_29_09.ppt>. Acesso em: 10 Jan. 2010.

KOIZUMI, M. S.; JORGE, M. H. P. Acidentes de Trânsito no Brasil: um atlas de sua distribuição. ABRAMET - Associação Brasileira de Medicina de Tráfego. São Paulo. 192 p. 2007.

KOLLER, S. et al. O perfil do caminhoneiro no Brasil. Programa de pós-graduação em psicologia da Universidade Federal do Rio Grande do Sul e Childhood Brasil - Instituto WCF. 2004. Disponível em: <http://www.namaocerta.org.br/pesquisa.php>. Acesso em 12 nov. 2009. 


\section{LEHMANN, G. Highway Recording Systems: A Report on European and US}

Experiences. International Symposium on transportation recorders. 3-5 Mai. 1999. Arlington, Virginia, EUA.

MATTOS, J. R. G, ALBANO, J. F. Veículos de carga e segurança rodoviária. VII SEPROSUL - Semana de Engenharia de Produção Sul-Americana, Salto, Uruguay, 2007.

MELLO, M.T.; TUFIK, S.; SANTOS, E. H. R. Distúrbios do sono, sonolência e acidentes de trânsito. Disponível em:

<http://www.estradas.com.br/sosestradas/estudos/dr_marco_t_mello/disturbios_do_sono_son olencia_e_acidentes_de_transito.doc>.Acesso em: 03/01/2010.

MENIG, P.; COVERDILL, C. Transportation Recorders on Commercial Vehicles. Freightliner Corporation. 1999. Disponível em: <http://www.ntsb.gov/events/symp_rec/proceedings/authors/menig.pdf $>$. Acesso em: 12 dez. 2009.

NTC - National Transport Comission. How to use Your New Work Diary. Disponível em: <http://www.ntc.gov.au/filemedia/bulletins/HVDF_HowToUseYourNewWorkDairy_Au.pdf> . Acesso em: 10/02/2010. Austrália. 2008.

\section{PALAZZI,C. E.; ROCCETTI, M.; FERRETTI, S. An Intervehicular Communication} Architecture for Safety and Entertainment. IEEE Transaction on intelligent transportation systems 1. 2009.

PARODI, L. Monitor das fraudes: O primeiro site brasileiro sobre combate a fraudes, lavagem de dinheiro e corrupção. Carteira nacional de habilitação - CNH. Disponível em: <http://www.fraudes.org/showpage1.asp?pg=258>. Acesso em: 17 Jan. 2010.

PETERS, T. Automobile navigation using a magnetic flux-gate compass. IEEE Transactions in Vehicular Technology, vol. VT-35, no. 2, pp. 41-47, Maio. 1986.

RIBEIRO, G. Como funciona o certificado digital. Disponível em: <http://informatica.hsw.uol.com.br/certificado-digital.htm>. Acesso em: 10 Dez 2009. 
RODRIGUES, T. N. Tempo ao volante: Uma abordagem sociológica da jornada de trabalho de motoristas rodoviários. Disponível em:

<http://www.estradas.com.br/sosestradas/articulistas/nivaldino/>. Acesso em: 08/07/2010.

RYCHTER, M. Functions and technology of digital tachographs systems with contemporary telematic system in road transport, on board informatics net and GPS system. Transport Problems 2009. Motor Transport institute. Polônia. Disponínel em: <http://www.transportproblems.polsl.pl/pl/Archiwum/2009/zeszyt1/2009t4z1_09.pdf>. Acesso em: 28 Dez. 2009.

RIZZOTTO, R. A. Morte no Trânsito: Tragédia Rodoviária. CNT - Confederação Nacional do Transporte. 2004. Disponível em: http://www.estradas.com.br/new/header_sites/sosestradas.asp. Acesso em: 19 out. 2009.

SCHIMIDT-COTTA, R. R. et al. VERONICA - Vehicle Event Recording Based on Intelligent Crash Assessment. Project Final Report. 29-11-2006. EUROPEAN COMMISSION DIRECTORATE GENERAL FOR ENERGY AND TRANSPORT.

SEGANTINE, Paulo C. L. GPS: Sistema de Posicionamento Global.181p. Apostila Escola de Engenharia de São Carlos, Universidade de São Paulo, São Paulo, 1995.

SERASA. O que é um CPF A3? Disponível em: <http://loja.certificadodigital.com.br/Serasa/SaibaMais/365/A3>. Acesso em: 17 Jan. 2010.

SEVA. Manual de instruções do tacógrafo modelo SV-2001. 2007. 22p. Manual de instruções do tacógrafo modelo SVT-3000A. 2001. 40p.

SIEMENS VDO. Manual de instruções do tacógrafo modelo DTCO 1381. 2005. 130p.

SILVA, E. V. P. Introdução à criptografia RSA. Universidade Estadual Paulista - UNESP. Escola de engenharia de Ilha Solteira. 2006. Disponível em:

<http://www.impa.br/opencms/pt/eventos/downloads/jornadas_2006/trabalhos/jornadas_elen_ pereira.pdf>. Acesso em 12 Jan. 2010. 
SILVA, R. A. C. Um Estudo Geral sobre VANETs. Departamento de Ciência da Computação. Universidade Federal da Bahia (UFBA). 2008. Disponível em: $<$ https://disciplinas.dcc.ufba.br/pub/MATA46/NotasDeAula/artigo_versao_final.pdf>. Acesso em: 20 Dez. 2009.

SILVEIRA, A. C. Avaliação de desempenho de aparelhos receptores GPS. Faculdade De Engenharia Agrícola, Universidade Estadual de Campinas, Campinas, janeiro de 2004.

SIRF, Technology Inc. SiRFstar III GSC3f/LPx High performance, lowest power flash GPS solution product overview. Rev. 1.0, 2008, Disponível em: <http://www.sirf.com/products/GSC3LPxProductInsert.pdf>. Acesso em: 16 Jan. 2010.

SKOG, I.; HANDEL P. In-car positioning and navigation technologies: A survey. IEEE transactions on intelligent transportation systems. Vol. 10. º1, Março de 2009.

SORIANO, F. et al. A comparison of different technologies for EFC and other ITS applications. IEEE Intelligent Transportation Systems Conference Proceedings. Oakland. 2001.

TANENBAUM, A. S. Redes de Computadores. Tradução da Terceira Edição. Editora Campus Ltda. Rio de Janeiro. 1997.

THOBER, D. S. ET AL. Resumo Executivo dos Requisitos Técnicos do SINIAV. Centro de Pesquisas Avançadas Wernher von Braun, Brasilia, 29-10-2009.

TRUCK SAFETY COALITION. Critics of recorder proposal blast agency. Disponível em: <http://www.trucksafety.org/Electronic_On-Board_Recorders.php>. Acesso em: 11 Jan. 2010.

VDO. Catálogo de redutores angulares. Disponível em: < http://www.vdo.com.br/generator/www/br/pt/vdo/main/products_solutions/fleet_management /tachographs/angle_drive/mtco_1324_pt.html>. Acesso em: 17 de dez. de 2009.

WOLFGANG, R.; WOLFGANG E. Smart Card Handbook. $3^{\text {a }}$ Edição. 1123p. Grã Bretanhã. Editora: John Wiley \& Sons, Ltd. 2002. 